
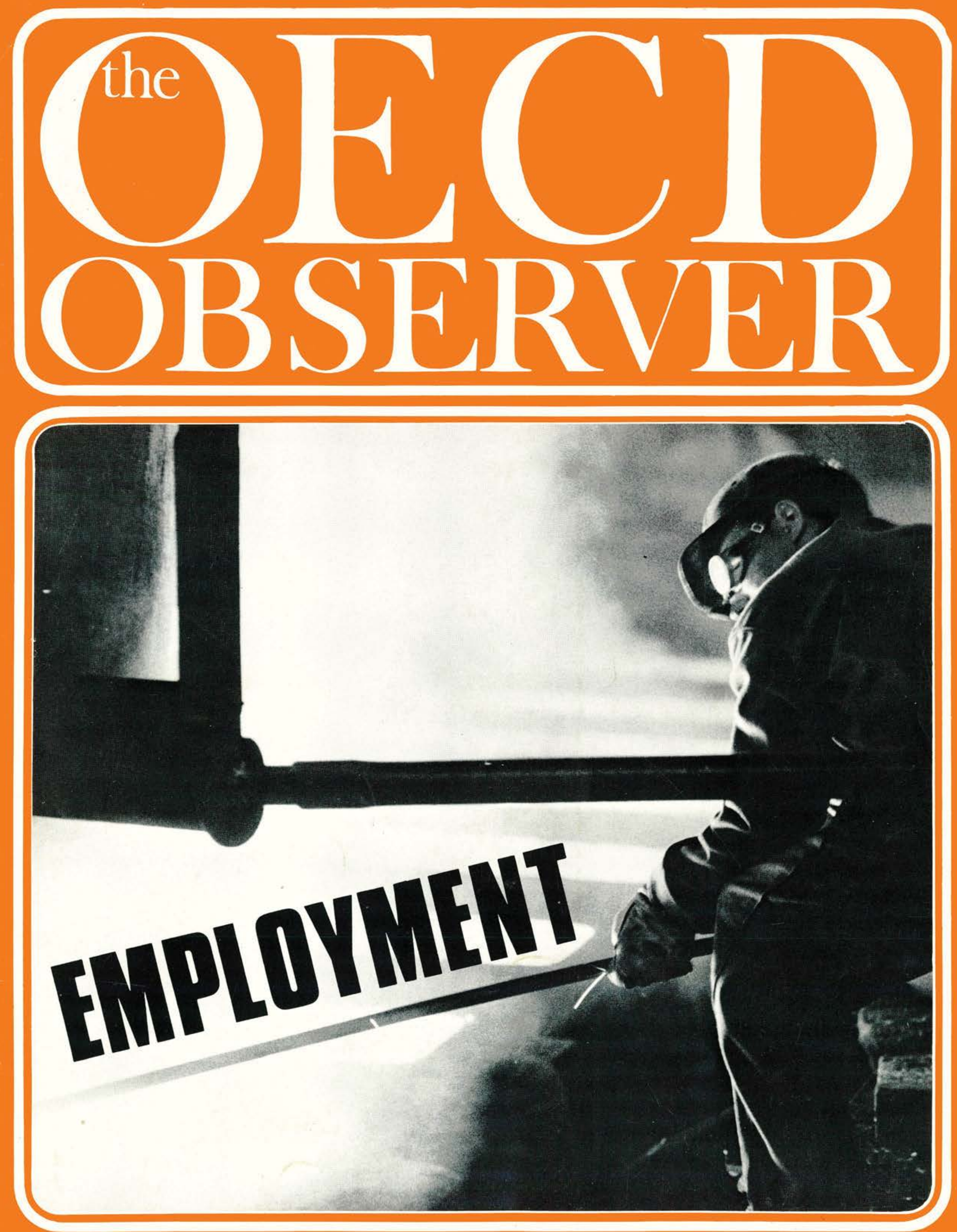

N8O/MARCH-APRIL 1976 


\section{Contents}

\section{MINISTERS DISCUSS EMPLOYMENT PROBLEMS}

Meeting of OECD Manpower and Social Affairs Committee at Ministerial Level

- Communique

- The Employment Challenge

by Emile van Lennep, Secretary General of OECD

- A Humanistic Approach to Employment

by Michel Durafour, French Minister of Labour and Ministerial Conference Chairman

- Report by the Manpower and Social Affairs Committee

- OECD Recommendation on a General Employment and Manpower Policy

- The Range of Employment and Manpower Measures

- Policy Measures in Current Use

- Some Indications for the Future

- Reflections by Ministers as to Necessary Action

MEMBER COUNTRIES' STATISTICS

1976 Edition - 12th Year

REDUCING DEPENDENCE ON IMPORTED OIL

by Dr. Ulf Lantzke, Executive Director of International Energy Agency

and Special Counsellor to Secretary General of the OECD

on Energy Questions

ANTI-RECESSION POLICIES IN SWEDEN

LOW-COST IMPROVEMENT OF THE URBAN ENVIRONMENT

BUILDING FOR EDUCATIONAL CHANGE

INAUGURAL MEETING OF THE "CLUB DES AMIS DU SAHEL"

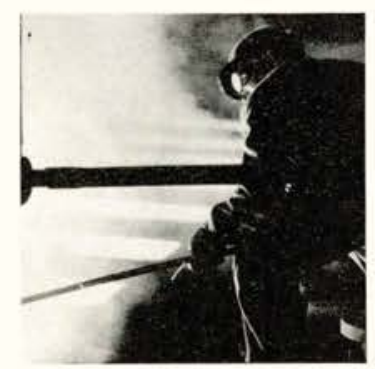

Cover: High unemployment with its social consequences, reduced working hours and diminishing numbers of job vacancies are part and parcel of an employment situation which led OECD's Manpower and Social Affairs Committee to call its first meeting at Ministerial level last month. The results of that meeting are described on pages 3-18.

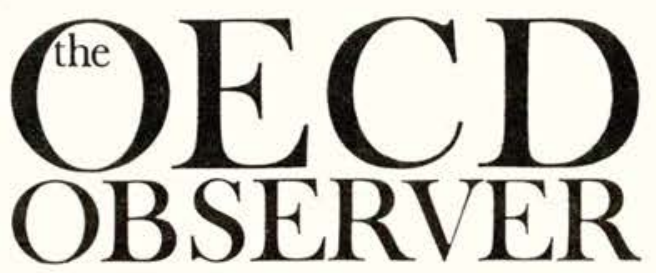

No 80

March-April 1976

Published bi-monthly in English and French by THE ORGANISATION FOR ECONOMIC CO-OPERATION AND DEVELOPMENT

\section{EDITORIAL OFFICES}

OECD Information Service, Château de la Muette, 2, rue André-Pascal, F 75775 PARIS, CEDEX 16.

Individual articles not copyrighted may be reprinted providing the credit line reads "Reprinted from the OECD Observer" plus date of issue, and two voucher copies are sent to the Editor. Signed articles reprinted must bear author's name.

The Organisation cannot be responsible for returning unsolicited manuscripts.

Signed articles express the opinions of the authors and do not necessarily represent the opinion of OECD.

Annual Subscription Rates (1976) : $£ 2.80$, $\$ 6.25$, F 25.00 .

Single copies : $£ 0.60, \$ 1.25$, F 5.00 .

EDITOR: Jane Bussière

Assistant Editor : Ulla Jeanneney

Art, Production and Layout:

Marc Delemme

Photo Research : Silvia Lépot

All correspondence should be addressed to the Editor.

PHOTOS: Cover: Italsider; pages 3-6: L. Jouan - OECD; page 7: Press Office of the President of France; page 15: Central Office of Information; pages 1618: L. Jouan-OECD; page 30: Christian Simonpietri - Sygma; page 34: OECD; page 38: Central Office of Information; pages 40-41 (top) L. Jouan - OECD (bottom) Studio Gora Sece, Dakar. 


\section{MINISTERS DISCUSS EMPLOYMENT PROBLEMS}

\section{Meeting of OECD \\ Manpower and Social Affairs Committee at Ministerial Level}

$\mathrm{T}$ he serious employment situation was the central issue at the first ministerial level meeting of the OECD Committee of Manpower and Social Affairs, which was held in Paris on 4th and 5th March under the Chairmanship of M. Michel Durafour, Minister of Labour of France. The Vice-Chairmen were the Hon. Robert K. Andras, P.C., M.P., Minister of Manpower and Immigration, Canada; Mr. Constantinos Laskaris, Minister of Labour, Greece; and Mr. Ingemund Bengtsson, Minister of Labour, Sweden.

Ministers reaffirmed the commitment of their Governments to

Chairman of the Ministerial Meeting, Michel Durafour, French Minister of Labour, second from left, with OECD officials. Left to right : James R. Gass, Director for Social Affairs, Manpower and Education; Emile van Lennep, Secretary General; Gérard Eldin, Deputy Secretary General.

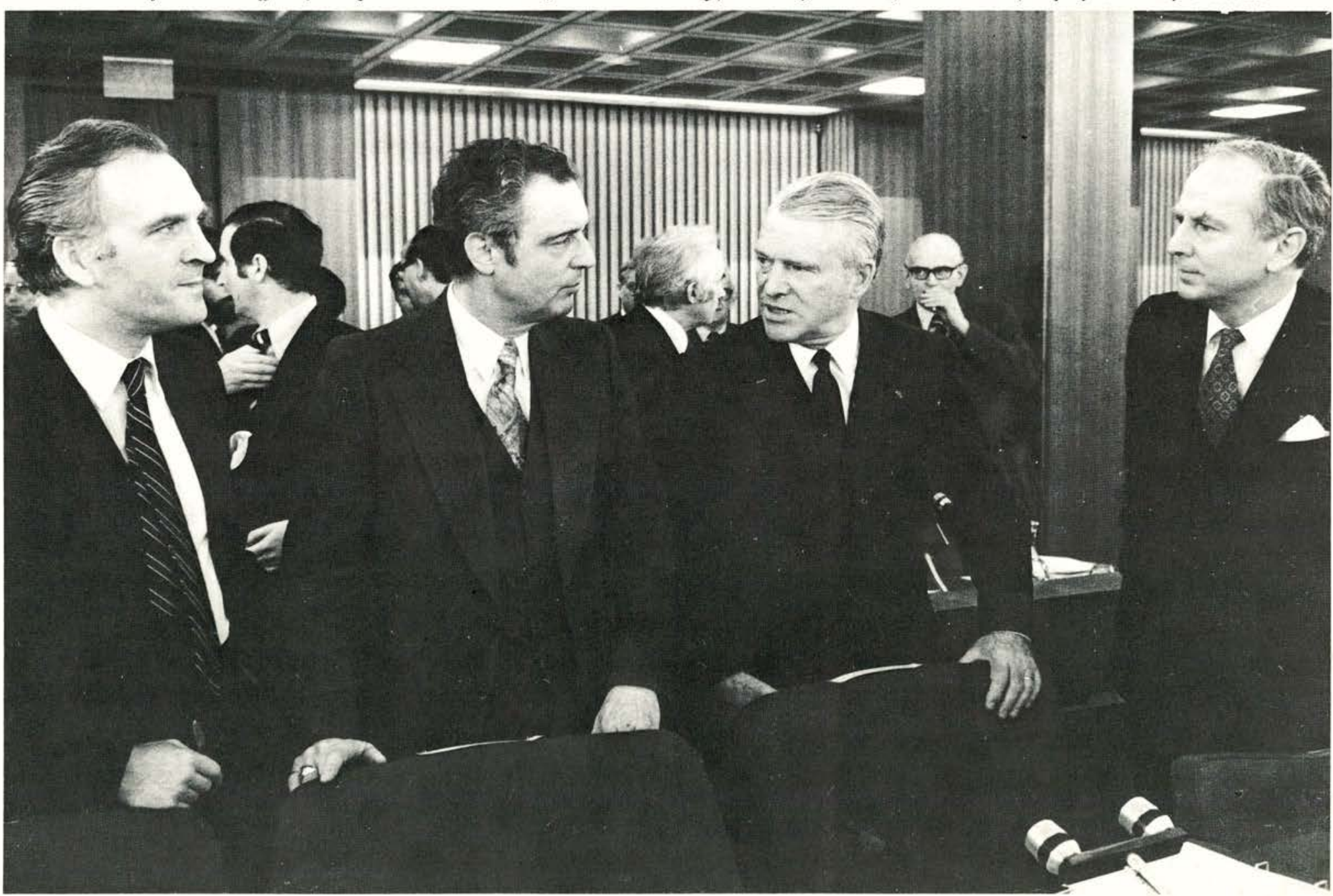


full employment as a main goal of policy, for which the restoration of adequate levels of economic activity, with the progressive reduction of inflation, is a major condition.

They noted that, notwithstanding the varying rates of economic recovery in the OECD countries, the reduction of unemployment may initially be delayed because in the early phase of the recovery enterprises will first tend to use existing manpower more fully and, in some countries, because of the impact of structural changes.

In this situation, Ministers stressed that a substantial recovery of employment will depend not only on the expansion of demand, but also on related special actions by employment and manpower authorities, to stimulate the creation of jobs and to assist workers to acquire the skills and move into the jobs needed as part of the economic upswing.

Ministers emphasized that in most countries there is a need for more active policies aimed at the provision of socially useful and economically acceptable alternatives to unemployment. They stressed in particular that manpower training could help the unemployed and new entrants to the labour market to acquire skills needed to enter expanding sectors of the economy. Temporary and selective subsidies to enterprises or reductions of charges on their payrolls should continue to be used or tested as a means to lower the costs to employers of expanding or maintaining employment during the economic upswing. Other possibilities include job-creation programmes in the private and public sectors, community employment projects and increased expenditure on public works. In any policy to assist the unemployed, Ministers stressed the need for special action to ensure that disadvantaged groups get their fair share of employment and training opportunities.

Looking beyond the immediate situation, Ministers agreed that the challenge facing the OECD countries is not only to reduce unemployment and avoid renewed inflation, but also to achieve full employment in ways relevant to emerging social aspirations and new economic conditions. The essential goal should be satisfying and socially useful careers for all. This will involve policies to increase the number and the quality of jobs, and to facilitate the balance between work, education and leisure that will assist long-term adjustment between the availability of jobs and the supply of labour, bearing in mind the needs, aspirations, and contributions of all groups in society.

To this end, Ministers agreed that there would be a need to pursue or, where appropriate, to consider new policies in areas such as: equity in access to employment opportunities; a wider range of interrelated education and work options for young people; improvement of working conditions and the content of jobs, especially for the less-skilled occupations; training and educational opportunities for adults, so as to help them to further develop as individuals and adjust their skills to economic and technological change; increased flexibility of career, educational and retirement patterns for all.

Ministers agreed that the above short-term and medium-term goals can only be attained if the OECD countries have efficient and adaptable economies, with adequate rates of growth and equity in the distribution of income. They agreed that employment and manpower policies can make an important contribution to this end by helping to moderate inflationary pressures, by reconciling employment security with the mobility needed to respond to new economic opportunities, and by developing the skills needed as part of economic growth. Closer linkages between employment and manpower policy and all relevant domains of economic policy are therefore needed as part of an effective employment strategy. The employment and manpower services of Member countries need to be strengthened to play their central role in such a strategy, bearing in mind variations in the role of government and in the institutional setting between countries.

Ministers requested that the OECD should assist Member countries to monitor employment trends and pool information on policies adopted to combat unemployment and moderate inflation.

Ministers agreed on the need for international cooperation so as to avoid beggar-thy-neighbour policies in the employment field. For example, major changes in migration flows between some European Member countries call for intensified cooperation between host countries and countries of origin, so that the burden of adjustment can be more equitably shared and economic and social development promoted. Ministers decided that these questions of migration between European Member countries should be studied by the existing bodies of the Organisation, strengthened if necessary by the establishment of a high level ad hoc group.

Employment and manpower policies may have an important role to play in enabling OECD Member countries to continue the trend towards freer international trade and investment. In particular, workers in industries affected should be assisted to adapt to structural changes resulting from changing patterns of international trade, bearing in mind the evolving relationship between industrialised countries and developing countries.

Manpower and employment policies directly affect the interests of both employers and workers. Ministers therefore agreed that the development and implementation of these policies require continuing cooperation and involvement of representative business and labour organisations in forms appropriate to each country's institutions.

In order to give effect to the above conclusions Ministers agreed on an OECD Recommendation on A General Employment and Manpower Policy (see page 9), which calls on Member countries to take appropriate action, as well as on the decisions in the annex below.

\section{Further Conclusions \\ of the Manpower and Social Affairs Committee at Ministerial Level}

The Committee decided:

On a proposal by Greece, to examine the possibility of instituting special machinery and the facilities of every kind with which such machinery could be provided, for facilitating the return of migrant workers, and to report to the Council.

On a proposal by Turkey, and taking account of the proposal by Portugal, to study, by creating if appropriate a special group for the purpose, the problems of employment and manpower in a long-term perspective and to work out a development strategy in the context of the problems of migration.

\section{The Committee:}

Supported the suggestion by the French Delegation consisting in organising within the framework of the OECD a meeting of independent experts of worldwide standing with the task of giving thought in a scientific context to the definition of active policies for achieving a better balance between the supply of and demand for employment, for a given level of activity.

Invited the Secretary General to put forward proposals to the Council for this purpose, taking account of the statements made by various delegations during the discussion. 


\title{
The Employment Challenge
}

\author{
by Emile van Lennep, Secretary General \\ of $O E C D(1)$
}

$\mathrm{E}$ mployment is a political, economic, social and human issue which must be tackled in all its elements. Its solution therefore requires a close partnership between economic policy and manpower and social policies. Two features of the problem need to be identified. First, there is the transitional problem: given existing levels of unemployment and likely rates of economic growth, the return to acceptable levels of manpower utilisation will be slow, and in some countries may take several years. Secondly, there are the longer-term effects of evolving structures of the labour force, attitudes to work and changing social objectives, which may affect employment in a fundamental sense.

\section{The Period Just Ahead}

Success in dealing with the transitional problem of high unemployment, depends primarily on economic management in the period immediately ahead. It is encouraging that the recovery which began in the middle of last year is roughly on course and that unemployment has begun to come down in the United States. Nevertheless, the signs are that it will be a relatively moderate recovery and that, in most countries, it will be some time before the rising trend in unemployment is reversed. As Ministers responsible for manpower and social affairs, you no doubt wish that the recovery could be more rapid. But, with a more rapid recovery, there would be a very real risk of a resurgence of inflation and a return to the traditional cycle of boom and bust, with quite possibly even higher levels of unemployment in the next recession. The right economic strategy, therefore, seems to be a moderate but sustained recovery over a number of years, which necessarily means a relatively slow recovery of employment in the OECD area as a whole.

The need to avoid a resurgence of inflation is not the only reason why it will take some time to bring down unemployment to acceptable levels. The growth of physical capacity has slowed down as a result of low levels of investment during — and in some countries already before - the present recession. Structural changes, and in particular the rise in energy prices, have rendered some plant and equipment obsolete. In a number of important countries a sustained period of high investment will be needed to provide adequate employment opportunities for the growing labour force. And the problem may be further complicated by the likelihood of rising participation rates, amongst other things due to more employment opportunities for women.

This economic situation means that there will be a continuing and urgent need at the national level for manpower, employment and income maintenance policies which will hold unemployment in check, assist manpower adaptation so as to exploit fully the potential for economic recovery, and ease the burden on those who, for some time still, will be on short-time or unemployed.

\section{The Benefits Issue}

Adequate benefits for short-term unemployment are, of course, an absolute priority. They ease inevitable frictional unemployment and minimise the personal hardships involved in searching for a new job. But high-level benefits for the long-term unemployed are a different social and economic issue, for there is a danger of turning into unemployables precisely those for whom social justice would require a special effort to get them into the labour market.

It is therefore necessary to ask how far we should go in looking upon income maintenance as the central policy for dealing with the unemployed. Certainly there is a case for a close examination of the costs and benefits of an accompanying policy of job creation, taking into account the net cost to the public purse and the benefits to the individual and society accruing from useful work rather than enforced idleness. No one would wish, except as a temporary measure for social reasons, to artificially stimulate labour-intensive activities or induce employers to employ more labour than they need. But governments today influence the labour market through a wide range of economic industrial, regional and technological policies. Selective manpower and employment programmes should be allied to these policies to make sure that - when economically and socially justified — jobs are maintained, stimulated or created.

But there is a real question here concerning the proper balance, in terms of economic efficiency and social equity, between policies to maintain the incomes of those out of work and policies to subsidise employment and create jobs.

\section{The International Implications}

The success of domestic policies is of course dependent to a significant extent on international cooperation. The fear of unemployment naturally leads to pressures to safeguard immediate national and sectoral interests, and thereby to export employment difficulties to others. In the field of trade, the OECD Member countries have successfully implemented a Trade Pledge whereby protective measures have been kept in check despite the combination of a severe recession and the inflationary and balance of payments difficulties caused by the sharp rise in oil prices. Given the slow recovery of employment and the serious problems which are likely to continue to face some countries and particular sectors of the economy, pressures to defend domestic employment are nevertheless likely to continue. It is therefore necessary to convince public opinion that high levels of income, employment and social services depend on cooperation within the framework of an international economic system in which all profit from a division of labour based on comparative advantage.

Comparative advantage between countries may of course change rapidly under the impact of the accelerating diffusion of knowhow and investment. We should therefore take an open and dynamic view of comparative economic advantage, rather than one which implies any static sharing-out of economic sectors between advanced and developing countries. This is particularly true in a period when traditional patterns of migration, such as

(1) Based on an introductory statement to the Ministers. 


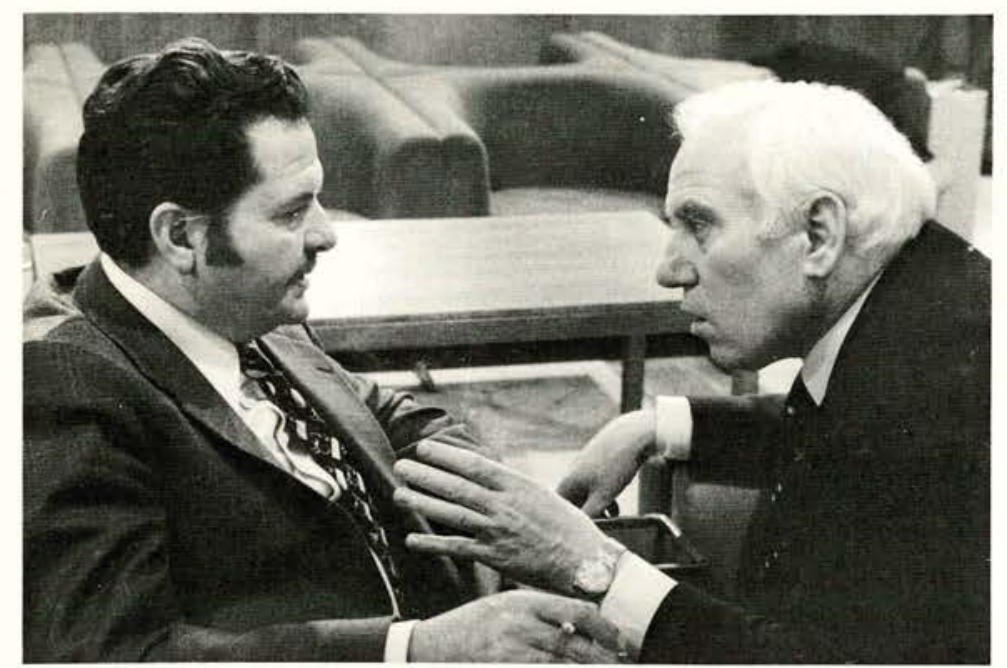

Benny Berg, Minister of Labour and Social Security of Luxembourg, left, and Walter Arendt, German Federal Minister of Labour and Social Affairs, right.
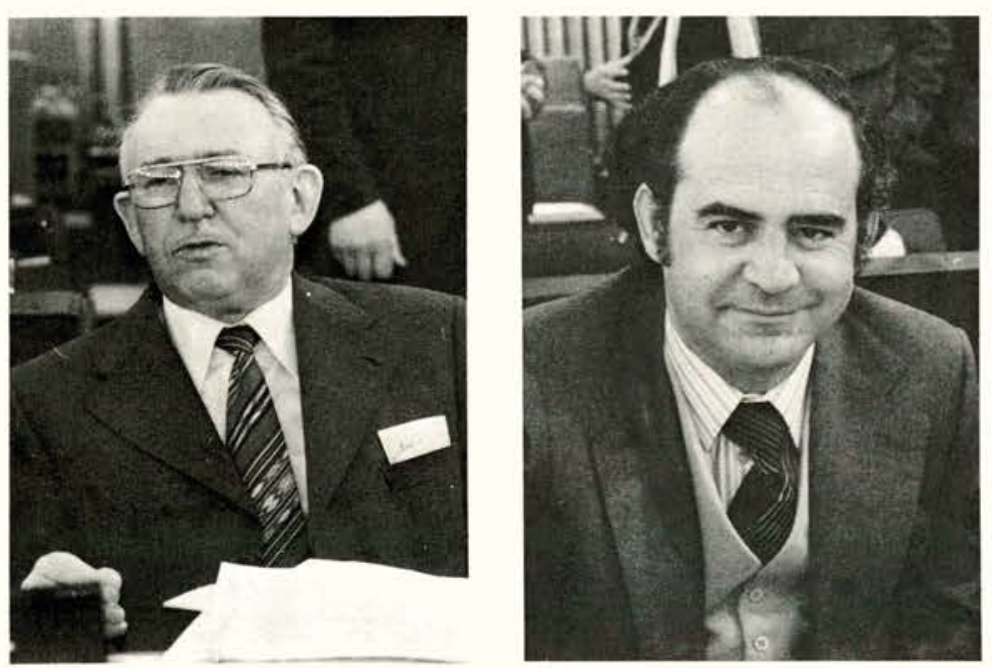

Left to right: Alfred Califice, Belgian Minister of Employment and Labour; Joao Pedro Tomaz Rosa, Portuguese Minister of Labour.

those between the OECD countries in recent years, are brought into question by the high levels of domestic unemployment. Cooperation between countries is indispensable in these circumstances, both to ensure the necessary social adjustments, and in the interest of the economic development of the sending countries.

\section{Economic Policy and Manpower Policy}

Given the likely trend of economic policies, domestic employment and manpower policy must be looked upon as essential partners of economic policy: not only to ease the social burden of unemployment, but also to stimulate the selective creation and maintenance of jobs, thereby giving economic policy more room for manœuvre. Increasingly, socially responsible incomes and price determination will also be necessary to ensure the right balance between growth, incomes and employment. The speedy and effective exchange of experience on these matters will surely be beneficial. At the international level, the maintenance of an open economic order can be assisted by employment and manpower policies which ensure that the costs of change are borne by society rather than by the individual while assisting workers to adapt to economic change.

In dealing with the problems of the next few years, which are
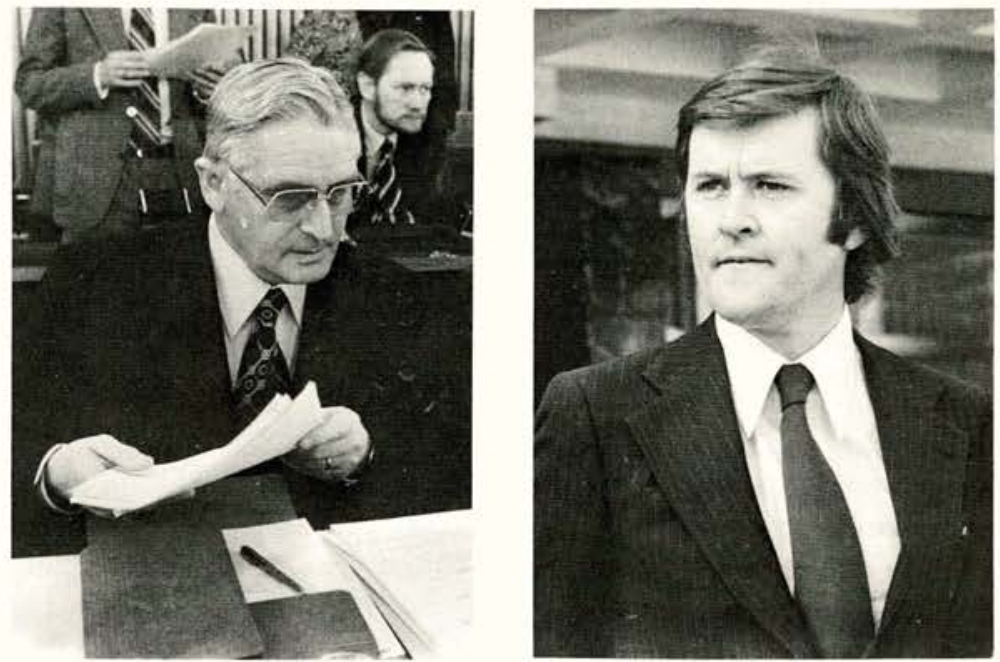

Ernst Brugger, Swiss Federal Counsellor, Head of the Federal Department for Public Economy, left, and Michael O'Leary, Irish Minister of Labour, right.

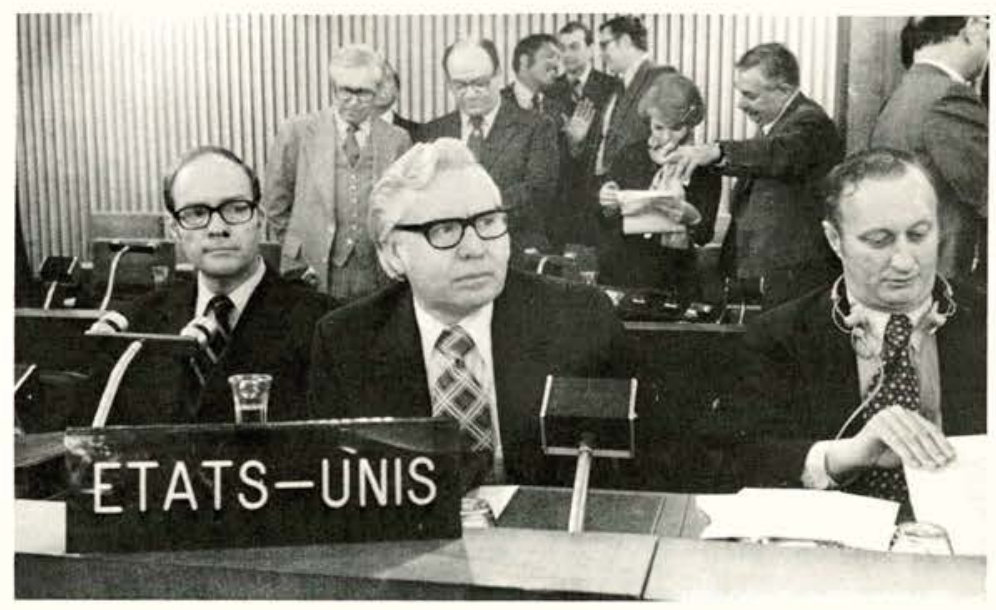

Left to right: Ambassador William C. Turner, Head of the Permanent U.S. Delegation to OECD, William J. Usery, U.S. Secretary of Labour, James P. Metcalf, Director of OECD Activities in the U.S. Department of Labour.

pressing and many, we should keep in mind the rapid pace of social change which is typical of our advanced societies. Rising levels of income lead to changing objectives, and the OECD countries have, since World War II, been devoting a growing share of resources to activities which, though recognised as socially useful, are outside the labour market as such. Moreover, the labour market in the strict sense is changing rapidly because of the rapid expansion of part-time work, more flexible careers, and new combinations of education, work and leisure. The objective of full employment may thus be evolving into one of "satisfying careers for all" - in which preparation for work, productive activity in the labour market, service to society in other forms, and the right to leisure and a dignified retirement, are seen in an integrated way. Such an integration of economic and social objectives could represent a return to a true political economy, one in which growth and welfare are seen together and in terms of the needs of the whole woman or man. It could constitute a worthy goal for the OECD countries in the decade to come.

The historian Toynbee has taught us that crisis is the mother of the creative response. In March 1976, the OECD countries are faced with an employment challenge that will not quickly run away as our economies revive. This first meeting at Ministerial level of the OECD Committee for Manpower and Social Affairs will, I hope, sow the seed for a renewed effort to achieve full employment, even if some hallowed economic principles and social traditions need to be looked at afresh to do so. 


\title{
A Humanistic Approach to Employment
}

\author{
by Michel Durafour, French Minister of Labour \\ and Ministerial Conference Chairman (1)
}

$\mathrm{T}$ he employment crisis affecting most of our societies may have different implications from one country to another, but usually the symptoms are the same, the rapidly increasing numbers of job seekers and the difficulties experienced by young people in entering working life, for example. Our countries are facing levels of unemployment unprecedented for several decades. The OECD area had nearly 15 million unemployed by the middle of 1975. To this deterioration and its effects as regards the operation of labour markets must be added the new relationships between employment and inflation, since high unemployment rates today exist side by side with substantial levels of inflation and a fall in growth.

\section{Root Causes}

What are the causes of such a situation, or what hypotheses can be put forward to explain it?

We should of course not overlook the sudden changes that have recently taken place in the international arena as regards energy, primary commodities, monetary markets and foodstuffs.

But perhaps we should adduce such deeper causes as the economic and social changes that have radically altered the previous characteristics of the employment problem and have gradually modified modern man's perception of his work.

The economic scene has gone through an astonishing process of change due to technological progress, new competition on world markets and a new distribution of investment, which have suddenly challenged the delicate balance between growth and inflation that our countries succeeded in achieving while maintaining the economy somewhere near full employment.

But it can also be claimed that the social scene in our countries has been undergoing a rapid change as a result of higher incomes and standards of living and education.

These advances may be said to have brought to light the ambiguous nature of work today, which fulfills certain needs while creating new dissatisfactions. I am not only referring to the familiar objections raised against the mirage of affluence, as summed up by Max Scheler in the phrase: "Modern man is a very sad person surrounded by very pleasant things".

What I also have in mind is the present-day dilemma of choosing between unemployment and work that is often of a fragmented and monotonous kind, between life without a job and life which begins only when the job ends. Hence an aspiration of our age is to restore the quality of work, and to make work not the price but the complement of leisure and culture.

All these contradictions and new aspirations have ended by creating or accentuating other kinds of imbalance. If we consider the people of the world as a whole, the disparities between rich and poor countries have not lessened; and within the Member countries themselves the crisis has helped to increase differences between regions, sectors of activity and socio-economic groups.

\section{The Policy Implications}

Faced with these many-sided problems, have we not been inclined to adopt incomplete policies? Have we not been content to take only the most urgent steps to protect jobs, by spreading the shortage as evenly as possible, by lightening the difficulties of unemployed workers as much as possible, and in short, by applying short-term economic remedies to a crisis which has taken us by surprise and is beyond our powers to overcome?

Our countries are today facing problems for which the traditional instruments of economic policy and employment policy now prove ill-suited. Merely to swap expedients for remedying some aspect or other of the employment crisis would in my view be useless. What we are called upon to do is to challenge our own answers to reflect on the entire complex idea of employment.

The questions before us may be reduced to a single one: how can economic imperatives be made compatible with social reality?

For there can be no question of neglecting economic imperatives in order to remedy the employment situation. The first requisite for a return to a satisfactory economic and social equilibrium is undoubtedly to achieve strong and sustained growth. Growth of the economy is in fact still the chief way to create jobs and reduce inequalities through a general improvement in the standard of living.

Any economic initiative must in future take account, if it is to succeed, of the social reality of employment, on which our thinking will be especially concentrated. For millions of workers, employment is above all a means of subsistence, enabling them to be fed, clothed and housed. It also provides an ideal opportunity for

\section{(1) Based on a statement to the Ministers.}

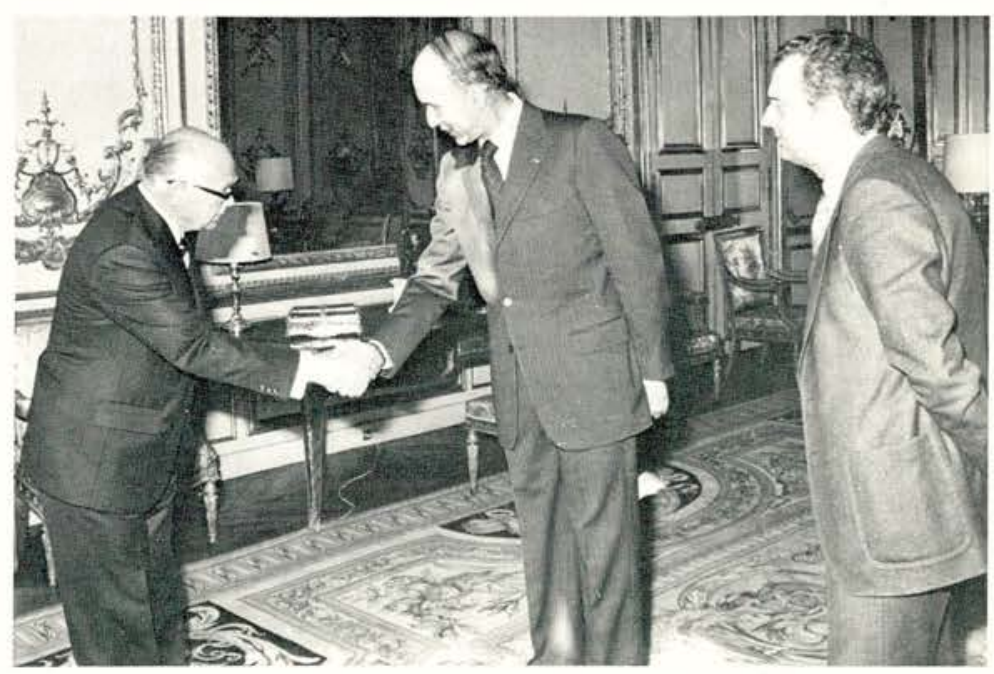

French President Valéry Giscard d'Estaing (centre) received the Ministers at the Elysée: here with Rudolf Häuser, Austrian Vice-Chancellor and Federal Minister for Social affairs; to right is Michel Durafour, French Minister of Labour and Chairman of the Conference. 
meeting people, for community life, and for self-fulfilment and self-expression.

And yet we know today that this natural function of employment has lost its true character in certain modern forms of work. The fragmentation of work destroys the satisfaction which time well spent provides by imposing on the worker a repetitive task, a life which goes by without anything happening, a life which ends before he has had time to live. In addition to robbing him in terms of time, industrial work also robs him in terms of space, since any natural capacity for communication becomes lost, not only as a result of migration to faceless urban areas, but also through a division of labour which, as Emile Durkheim has already pointed out, cuts the worker off from his place of origin, from the unknown consumer, and from his own product, of which he makes only a minute part.

Hence we can no doubt pool our thoughts in order to work out jointly a humanistic approach to employment. We should of course begin by reflecting on the re-organisation of fragmented tasks, and on improving the flow of information to workers, which seems to me essential. Perhaps we should also consider better ways of meeting the desire of workers for stability and security.

\section{Report by OECD's Manpower and Social Affairs Committee $(1)$}

\section{The Challenge}

A recommendation by OECD's Council in 1964 that Member countries adopt an Active Manpower Policy emphasized the importance of supplementing economic policies for growth with selective manpower adaptation and employment creation measures. It continues to be relevant in an economic and social context in which Member countries face a major challenge: how to return to full employment and a better utilisation of resources without introducing additional inflationary pressures.

However, the economic and social developments of the past decade have created new and difficult challenges such as the simultaneous appearance of high rates of inflation and unemployment and the unprecedented shocks applied to the world market by decreased petroleum supplies, shortages of food and raw materials.

The constraint which keeps governments from expanding aggregate activity more rapidly is the danger that an economic downturn more serious than that experienced in the past few years would be inevitable.

New links therefore need to be forged between macro-economic policy and selective employment policies in a manner which is expansionist with regard to production and employment and contributes as much as possible to the struggle against inflation.

The problems of unemployment and inflation must be dealt with in the context of longer-term developments which affect the difficulty of stabilising total employment at a level which fully utilises manpower resources.

These developments include new and more demanding job security rules and more liberal social insurance systems; the tendency for the risks of unemployment to be particularly concentrated among certain disadvantaged groups and areas, for which special measures must be developed to provide adequate employment opportunities; the increasing number of families in which both parents are employed as a result of the growing number of women who are seeking educational, working, social security, and family arrangements which reflect their aspirations to equality; increasing demands for a more equitable distribution of income; the need for adjustments to new relationships with developing countries, the increasing speed of the diffusion of technological innovations, reduction of trade barriers, expansion and versatility of international capital markets, and other factors increasing international interdependence; the rising level of education and increasing occupational specialisation leading to the need for greater coherence of the educational system and working life; rising expectations regarding careers and the quality of working life; and the increasing proportion of each country's income that goes to public authorities for government budgets and social insurance systems.

All of these new demands and pressing challenges emphasize the need to review and up-date the principles guiding the formulation of employment and manpower policy and to assess the measures for implementing that policy.

\section{Guiding Principles}

\section{- The Full-Employment Objective}

The report reaffirms the commitment of Member countries to full employment as a goal of policy but notes that it has qualitative as well as quantitative dimensions. New economic and social conditions are seen to call for an explicit and positive strategy not only for maintaining but for creating employment opportunities.

\section{- Employment Policy and Economic Policy}

The need for governments to improve the inter-relationship of overall economic policy with employment and manpower policy is emphasized. Although the ultimate authority for developing selective fiscal and monetary measures rests with economic authorities, the knowledge and analytical capability of those responsible for manpower programmes is a necessary ingredient.

Short-run objectives must be related to the long-range goals of economic growth, attractive employment opportunities, equality of opportunity in the labour market, and an adequate and reliable income.

Of particular importance, the report notes, is the need to recognise the role of capital investment in expanding and modernising industrial plant and equipment.

\section{- Measures to Stimulate Employment}

Selective employment measures are directed to particular factors of production, regions, industries or economic sectors and often operate through indirect effects.

(1) The full text is available from OECD's Social Affairs, Manpower and Education Directorate. 
Since the cost of income maintenance of the unemployed is a large proportion of the budget in certain countries, expenditures on employment creation may well be counterbalanced by the consequent savings of unemployment benefits and the public revenues generated. It may also be possible to direct selective employment-creating activities in such a way that employment growth will have a minimal inflationary impact.

Selective employment measures, directed at regions and sectors suffering undue economic hardship, can also be and are being employed by Member countries. Depending on the phase of the cycle, such measures may be stepped up or down, but are basically designed to remedy structural problems.

\section{- Manpower Adaptation}

Vigorous measures are required to facilitate and stimulate the adaptation of people to the changing pattern of manpower requirements. Workers may be assisted to change area or occupation the report notes. Slack periods can be productively used to enable workers to acquire new skills and educational activities (with appropriate income maintenance) can alleviate unemployment.

Advance planning, quick adaptation, and the development of current labour market information and economic forecasting capabilities are among the requisites for flexible responsive action.

\section{- Social Equity and Employment}

The modification of inequitable and discriminatory employment patterns depends not only on changes in the labour market but also on reforms of educational and community institutions. It is essential to introduce measures which help to eliminate artificial barriers to employment as well as to enrich job content, in particular through the upgrading of manual work. Measures to create employment and rehabilitation measures can assist disadvantaged groups. These are the qualitative aspects of full employment.

New initiatives, relating to both employment and education, the report notes, are required to deal with the employment problems of youth.

\section{Recommendation on a General Employment and Manpower Policy}

Adopted by OECD's Council on 5th March 1976

$\mathrm{O}$ ECD's Council has on the proposal of the Manpower and Social Affairs Committee at Ministerial level recommended that Member countries periodically examine their general employment and manpower policy so as to attain the objective of full employment, in particular by :

- continuing implementation of the principles of an active manpower policy contained in an OECD Council Recommendation of 21st May 1964 reinforced by a general and positive strategy for creating and maintaining employment and improved conditions of working life for all those who are able and want to work, with the support of relevant economic, employment, manpower and social policies;

- the close linking of employment and manpower policy and general economic policy, with the aim of achieving full employment objectives and improved quality of working life in the context of social and economic progress;

- systematic use and evaluation as appropriate of selective employment and manpower measures, with the objective of achieving and maintaining high levels of employment and balance between the supply and demand of labour in ways which contribute as much as possible to the struggle against inflation;

- special assistance to disadvantaged groups to enter, remain in or return to employment, thereby promoting more equity in the distribution of employment opportunities and income;

- balanced development of income maintenance, and of positive manpower utilisation measures which ensure the earliest possible return to employment, on the basis that it is preferable to spend money on activities which contribute to the expansion of employment;

- international cooperation in order that national employment and manpower policies and free international trade and investment are mutually consistent, so as to minimise the social costs of adjusting workers to structural changes which result from changing patterns of international trade;

- implementation between the OECD countries concerned of the guiding principles (1) for facilitating the orientation of migration policies and their concertation at international level;

- organisational arrangements within national administrations for the coordi- nation of all elements of policy affecting employment and manpower, in particular so that manpower authorities may help to ensure that the various elements of an employment strategy are taken into account in all fields of social and economic life;

- continuing cooperation and involvement of workers, employers and their representatives as an important aspect of total manpower and employment policy.

The Council invited Member countries to report to the Organisation on steps taken by them to implement this Recommendation, not later than the 31st March 1977, and subsequently at intervals to be determined by the Manpower and Social Affairs Committee.

It also endorsed the views expressed in a report of OECD's Manpower and Social Affairs Committee the main points of which are summarised above.

(1) As formulated in the Report of the Manpower and Social Affairs Committee on the Future Orientation of the Activity of the Organisation in the Field of International Migration referred to above, the OECD countries concerned being defined as those which have adhered to the Council's Decision governing the employment of nationals of Member countries. 


\section{Manpower Utilisation (Annual average compound rates of change)}

A significant feature of the present recession is that employment has not declined nearly as much as historic relationships with output would suggest. From 1973 to 1975 employment has generally grown more slowly than in the boom years 1960 to 1970 or has fallen, but so far the maximum declines in employment in this recession have not been much greater than those that occurred in the 1960s. However, it may well turn out that the declines in employment are not yet complete for many countries.
A good deal of the slack in manpower utilisation which has developed during the recession has been absorbed by various measures which have diverted the growth of overt unemployment. Working hours have fallen in a number of countries, jobs have been preserved by subsidies to employers, by restrictions on dismissals or deterrents such as redundancy payments. As a result output per employee has declined in many cases.

Table 1 also gives some indication of the mo- vement in working hours in the major countries during the recession. Many of the figures refer only to manufacturing and may be more sensitive to recession than those for the economy as a whole, but they do indicate that working hours have dropped more than the 1960-70 trend would have suggested in all countries. The biggest fall has been in Japan. The figures in the table explain some of the fall in output per employee but the fall in working hours does not explain the whole of this decline by any means.

\begin{tabular}{|c|c|c|c|c|c|c|c|c|}
\hline & \multicolumn{2}{|c|}{ Output (GDP) } & \multicolumn{2}{|c|}{ Employment } & \multicolumn{2}{|c|}{$\begin{array}{c}\text { Hours Worked } \\
\text { per Person }\end{array}$} & \multicolumn{2}{|c|}{$\begin{array}{l}\text { Output Per } \\
\text { Man Hour }\end{array}$} \\
\hline & $1960-73$ & $1973-75$ & $1960-73$ & $1973-75$ & $1960-73$ & $1973-75$ & $1960-73$ & $1973-75$ \\
\hline Australia & 5.0 & 1.3 & 2.6 & 0.3 & n.a. & -0.8 & n.a. & 1.8 \\
\hline Austria & 5.1 & 0.6 & -0.6 & -1.2 & -0.7 & -2.6 & 6.4 & 4.5 \\
\hline Belgium & 4.9 & 0.5 & 0.7 & n.a. & -1.2 & n.a. & 5.4 & n.a. \\
\hline Canada & 5.4 & 0.9 & 2.9 & 3.1 & -0.3 & -1.4 & 2.8 & -0.8 \\
\hline Denmark & 4.7 & -0.6 & 1.3 & n.a. & -1.5 & n.a. & 5.0 & n.a. \\
\hline Finland & 5.2 & -1.7 & 0.3 & 1.6 & -1.3 & n.a. & 6.3 & n.a. \\
\hline France & 5.8 & 0.9 & 0.7 & $(-0.5)$ & -0.5 & -2.1 & 5.5 & 3.6 \\
\hline Germany & 4.7 & -1.6 & 0.1 & -2.8 & -0.9 & -2.7 & 5.5 & 4.0 \\
\hline Italy & 5.1 & -0.7 & -0.7 & 1.2 & -1.9 & n.a. & 7.8 & n.a. \\
\hline Japan & 10.3 & -0.2 & 1.2 & -0.8 & -1.0 & -5.3 & 10.1 & 6.2 \\
\hline Netherlands & 5.2 & 0.6 & 0.9 & n.a. & n.a. & n.a. & n.a. & n.a. \\
\hline Norway & 4.9 & 3.7 & 1.1 & 1.2 & -1.2 & 0.0 & 4.9 & 2.5 \\
\hline Spain & 7.4 & 2.0 & 0.8 & n.a. & 0.0 & n.a. & 6.5 & n.a. \\
\hline Sweden & 3.9 & 2.0 & 0.6 & 2.3 & -1.3 & n.a. & 4.6 & n.a. \\
\hline Switzerland & 4.4 & -2.5 & 1.3 & n.a. & -0.5 & -1.0 & 3.5 & n.a. \\
\hline U.K. & 2.9 & -0.7 & 0.1 & 0.0 & -0.5 & -0.8 & 3.4 & 0.1 \\
\hline U.S. & 4.3 & -2.5 & 1.9 & 0.1 & 0.1 & -0.2 & 2.3 & -2.4 \\
\hline
\end{tabular}

Sources: OECD National Accounts of OECD Countries 1950-68 for 1960-62; OECD National Accounts of OECD Countries 1962-73 for 1962-70; and OECD Main Economic Indicators, February 1976 for 1970-75.

OECD Labour Force Statistics, Yearbook and Quarterly Issues, information and estimates supplied by OECD Statistics Division.
Main Economic Indicators, OECD, Bulletin of Labour Statistics, ILO, and national sources.

Notes: The figures for hours worked for Austria, Canada, France, Spain, Switzerland and United States are for manufacturing. For the other countries they have a somewhat wider coverage. 1975 estimates based on figures for months presently available.
Governments, unions and employers need increasingly to develop new ways to meet the needs of workers for increased satisfaction from work, and a working environment in which they are able more fully to develop and use their talents, and, in a manner consistent with the traditions of each country, influence decisions affecting their working life.

\section{- The Integration of Income Maintenance and Manpower Development Policy}

The provision of adequate incomes for those unemployed is an essential element of social justice. Yet unemployment benefit systems now approaching universality, require reappraisal if they are to be adapted to the needs of the long-term unemployed and to financial constraints. Higher and longer-duration unemployment, together with improved benefits in an inflationary context, have contributed to escalation of income support expenditures by governments.

These and other considerations lead to the conclusion that Member governments would better meet their economic and social objectives by actively exploring and promoting positive manpower development and employment creation measures on the principle that it is better to pay people to be gainfully occupied than for them to remain unemployed.

\section{- International Cooperation}

Employment and manpower policies have an important role to play in enabling OECD countries to continue the trend towards freer international trade and investment. Workers in industries affected by international trade must be assisted to adapt to structural changes resulting from changing patterns of trade. Such assistance will ensure that society shares the cost of readjustment with workers adversely affected and will reduce pressure on governments to introduce "beggar-thy-neighbour" policies which would prove disastrous to Member countries.

\section{- Migration}

International coordination is also called for in developing consultative arrangements for regulating the flows of migrant workers between Member countries. European Member countries have agreed to a set of principles to guide the orientation of their countries' policies on migration and, notes the report, reaffirm these principles.

The respective roles of governments of immigration countries and emigration countries and the need for coordinated action on policies to promote or restrict migratory flow are discussed with respect to European countries. 


\section{A. UNEMPLOYMENT RATES (unemployment as a percentage of total labour force)}

Chart A shows the cyclical pattern in the rate of unemployment during the recession in comparison to earlier trends. Here, as with the employment figures, the impact of the recession has been a good deal less than the decline in output would suggest. It should be noted that the differences in absolute levels of unemployment between countries are not strictly comparable because of differences in measurement techniques. The figures are presented as percentages of the total labour force in all cases.
The figures in the table may well differ from those normally presented in national estimates (e.g. the U.S. and Canada normally present unemployment as a per cent of the civilian labour force).

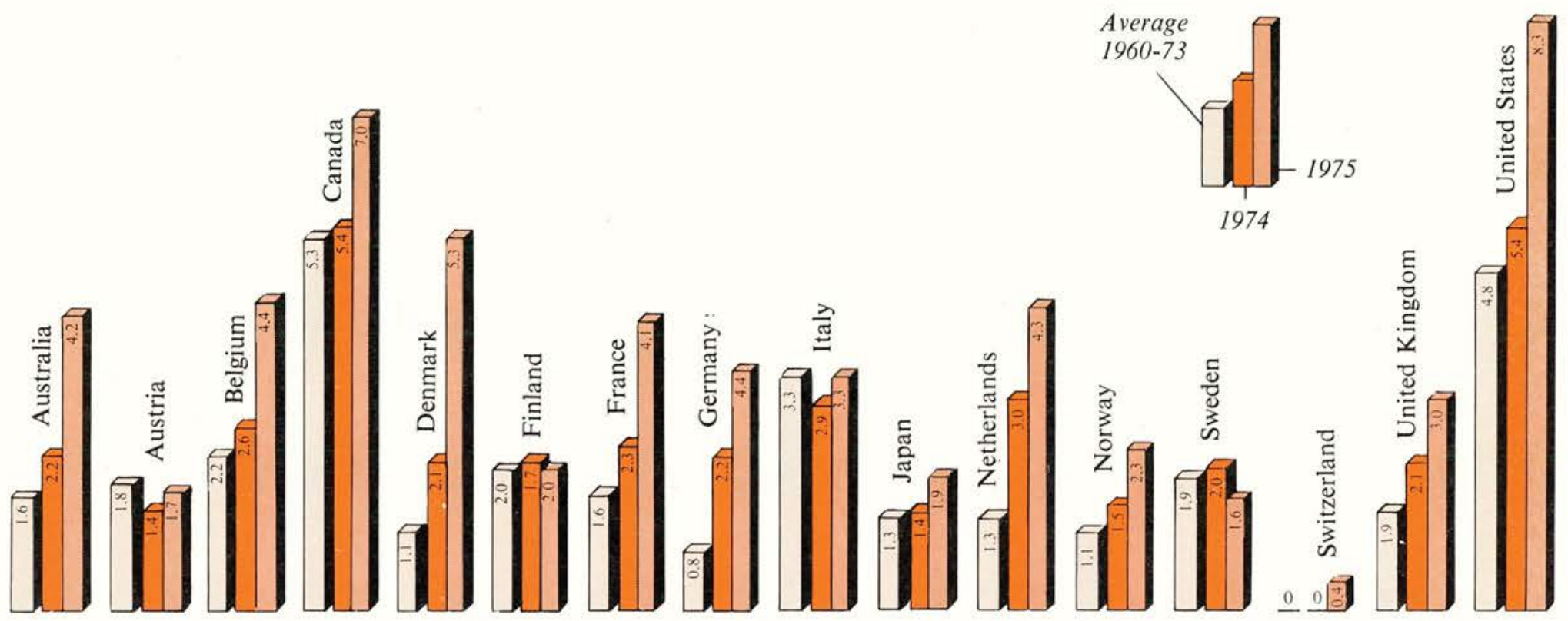

Source :

OECD Labour Force Statistics 1960-71 and 1962-73. OECD Labour Force Statistics quarterly supplement for Australia, Austria, Canada, Finland, Germany, Italy, Japan, Norway, Sweden, United Kingdom, United States for 1974 and 1975 . Where the 1975 annual figure was

not available in the supplement it was estimated from the available quarterly figures. Figures for 1974 and 1975 for Austria, Belgium, Denmark, France, Netherlands are estimates of the Secretariat. 1974 and 1975 figures for Switzerland supplied by the Swiss authorities. The table refers to annual data.

\section{B. JOB VACANCIES (Average $1973=100$ )}

The weakness of the employment situation is clearly indicated by the number of job vacancies. Vacancies were low in 1975 com- pared with 1974, save in the case of Sweden and Switzerland. It seems likely that vacancies will remain low and the labour market weak, well after recovery in output has developed because of the relatively low utilisation of employed manpower in many countries.

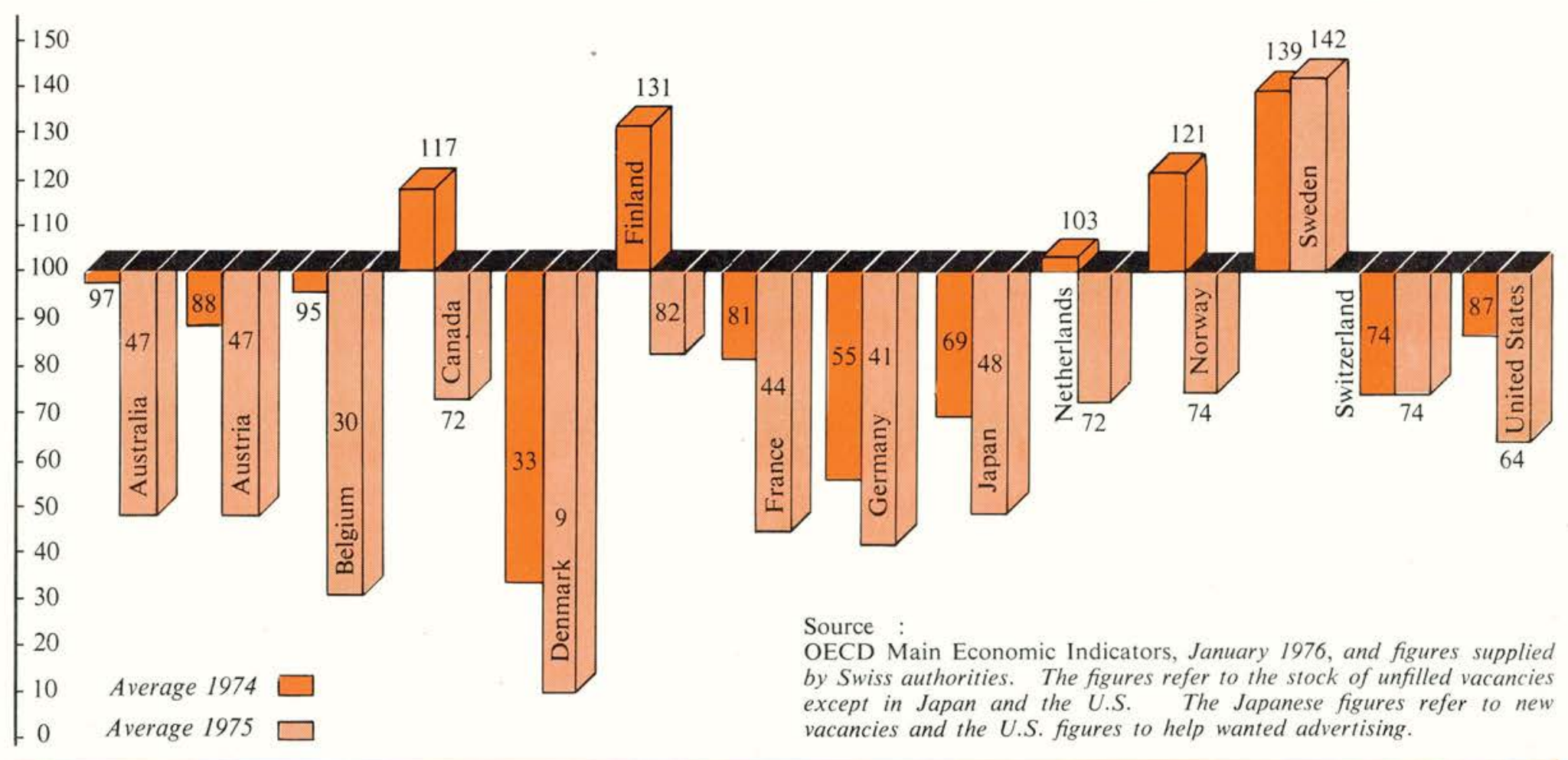


A new strategy of international economic and social adjustment is advocated; it gives increasing importance to cooperation of immigration countries in the industrial and technological development of emigration countries as an alternative or complement to migration.

\section{- Cooperation with Employers and Unions}

As employment and manpower policies directly affect the interests of employers and trade unions, the need for consultation is stressed as is the need for continuing cooperation and involvement of all parties in employment and manpower policy.

\section{Policy Instruments}

In their endeavour to provide employment for all those wishing and able to work, Member countries have developed a variety of employment and manpower policy instruments. (See below).

\section{The Coordination of Policy and Its Implementation}

The need for adequate organisational arrangements and resources is stressed. Three important elements remain to be achieved if Member countries are effectively to pursue manpower policy objectives. First, the institutions responsible for implementing manpower policy must be closely coordinated with other forms of social policy which have manpower consequences. This extends beyond the "traditional" monetary and fiscal policies to include social security and welfare, immigration, education and training, housing, transportation, agriculture, energy and international trade policy. Second, a substantial improvement in techniques is required to assess systematically the manpower consequences of decisions in the foregoing policy areas. Third, the base of knowledge about the ways the labour market operates and the quantity and quality of data reflecting these operations must be significantly increased.

The administrative burdens which fall on manpower agencies and public employment services when unemployment is high should not undermine their capacity to play a positive role in the formulation and implementation of a coordinated employment strategy, the report notes. The function of placement should for example be vigorously pursued and complemented by an increasing provision of vocational information and counselling.

Finally there is a need for improved links between public measures and decision-making in enterprises, where most of the actual decisions affecting employed workers are taken. Since the policies of governments have cost implications for enterprises, and the decisions of enterprises often have costs for society, the efficient achievement of national economic and social objectives is dependent on the optimum allocation of these costs.

\section{The Ranje of Employment and Manpower Policy Measures}

\section{Selective promotion of employment opportunities for specific areas, industries, groups or periods of time}

- direct employment incentives for private and public undertakings to increase, maintain or restructure manpower requirements

- indirect employment incentives for financial support of training, stock-piling, work environment improvements, etc.

- tax allowances and other subsidies for investments providing new employment and for reducing variations in investments

- regional development plans, regulation of the location of new or enlarged enterprises and reallocation of tax revenues to assist underdeveloped regions

- advance preparation of public investment projects (and central government support to local authorities) to be implemented at short notice to counteract reductions in employment

- temporary hiring of unemployed persons in current public service activities (public service employment), or in publicly financed community projects
- public works and government procurement orders specifically organised and timed to counteract unemployment

- timing of foreseen changes in the public service workforce and general workingtime regulations so as to counterbalance variations in manpower requirements

- special incentives for seasonal stabilisation of employment in relevant industries

- sheltered workshops, quota systems, and anti-discrimination laws and regulations for disadvantaged groups.

\section{Maintaining job attachments and employment}

- promotion of employment security for individuals by legislation and severance pay arrangements

- assistance to weak firms and sectors for temporary continuation or for conversion of production

- training arrangements within enterprises during slack periods

- promoting workers' acceptance of technological change by adjustment assistance or adequate compensation
- benefits for short-time work or temporary lay-offs

III. Facilitating manpower adaptation, better labour market functioning and work environment improvements

- development of the public employment service, including:

- improvement of information about vacancies and job seekers, comprehensive statistics, fuller notification of vacancies, establishment of "job banks" by computer techniques

- advance notice concerning employment variations

- manpower forecasting, vocational guidance and testing facilities

- cooperation with employers and trade unions to develop manpower planning in enterprises

- promotion of occupational mobility by recurrent education and training

- transitional arrangements for young people moving from school to work (sandwich courses, work-related instruction, etc.) 


\section{2 - Unemployment}

... by Sex (percentages)

\begin{tabular}{|c|c|c|c|}
\hline & $\begin{array}{c}\text { Reference } \\
\text { Quarter }\end{array}$ & $\begin{array}{c}\text { Male } \\
\text { Unemploy- } \\
\text { ment as } \\
\text { Percent of } \\
\text { Male } \\
\text { Labour Force }\end{array}$ & $\begin{array}{c}\text { Female } \\
\text { Unemploy- } \\
\text { ment as } \\
\text { Percent of } \\
\text { Female } \\
\text { Labour Force }\end{array}$ \\
\hline Germany & 1974 Q4 & 2.4 & 3.3 \\
\hline Australia & 1975 average & 3.4 & 5.7 \\
\hline Canada & 1975 average & 7.3 & 6.4 \\
\hline United States & 1975 average & 7.6 & 9.3 \\
\hline Finland & 1975 Q3 & 1.9 & 2.2 \\
\hline France & 1974 average & 1.9 & 2.9 \\
\hline Italy & 1975 average & 2.8 & 4.6 \\
\hline Japan & 1975 Q3 & 1.8 & 1.6 \\
\hline Norway & 1975 average & 1.9 & 3.1 \\
\hline $\begin{array}{l}\text { United } \\
\text { Kingdom }\end{array}$ & 1975 Q2 & (4.4) & $(1.7)$ \\
\hline Sweden & 1975 average & 1.3 & 2.0 \\
\hline
\end{tabular}

Source : $O E C D$ Labour Force Statistics, Quarterly Bulletin.
... by Age Group (*)

\begin{tabular}{l|l|l|l|c}
\hline & Reference Period & $15-24$ & $25-54$ & $55+$ \\
\hline Germany & 1974 Q3 & $28^{\mathrm{b}}$ & 60 & 12 \\
Australia & 1975 Q3 & 55 & 39 & 6 \\
Canada & 1975 average & $49^{\mathrm{a}}$ & 43 & 8 \\
United States & 1975 average & $46^{\mathrm{e}}$ & 46 & 8 \\
France & 1975 Q4 & $46^{\mathrm{b}}$ & $49^{\mathrm{d}}$ & $5^{\mathrm{e}}$ \\
Italy & 1975 average & 64 & 34 & 2 \\
Japan & 1975 Q3 & 23 & 59 & 18 \\
United & & & & \\
Kingdom & 1975 Q3 & $42^{\mathrm{b}}$ & 42 & 17 \\
Sweden & 1975 average & $37^{\mathrm{c}}$ & 42 & 21 \\
& & & & \\
\hline
\end{tabular}

Source : Quarterly supplement to OECD Labour Force Statistics.

Notes a: Age group 14-24.

$b$ : No lower age limit.

$c$ : Age group 16-24.

d: Age group 25-59.

e : Age group $60+$.

$f$ : Data refer to job applicants still registered at the end of each month.

(*) The figures represent the percentage of the total unemployed belonging to each age group.
- facilitating geographical mobility (financial assistance for distant job search, moving allowances, andhelp with resettlement and social adjustment in a new environment)

- cooperation between authorities responsible for manpower policy, public transportation and residential construction to provide travel facilities and housing in appropriate areas

- child-care facilities for mothers and other persons with family responsibilities desiring employment

- training and orientation facilities for persons wishing to return to employment

- special incentives to alleviate patterns of male-female occupational segregation

- reception services in cities receiving large numbers of migrants from rural areas

- rehabilitation, training, new work experience opportunities, and guidance and adjustment assistance for socially and medically handicapped

- better access to suitable training opportunities for older workers

- adjustment of work organisation and work places to overcome individual handicaps

- transferable pension rights

- elimination of age limits for hiring in private and public employment.

\section{Flexibility of working life}

- promotion of more extensive use of education and training facilities in situations of economic slack

- promotion of voluntary variations in the duration of work to improve balance in the labour market

- introduction of flexible hours and holidays, part-time and intermittent work, to assist the employment of persons with special constraints or preferences

- elimination of legal and contractual obstacles to part-time and flexible working hours, whenever this is compatible with social protection needs

- introduction of flexible retirement and pension facilities (access to early, temporary, partial, postponed pensions or reentry of retirees into employment) combined with incentives for individuals voluntarily to use such facilities so as to help counterbalance variations in manpower requirements.

\section{Organisation of migratory flows}

- guide placement and job search of migrants through public employment services of home and host countries and cooperation between these services

- preparation of would-be emigrants in home country and social adjustment of immigrants and their families in host country (information, teaching of both languages, occupational training, housing and reception services)

- counteracting discriminatory hiring and discharge of foreign workers by social protection laws

- cooperation between countries concerning the orientation of investments between countries to regions in greatest need of new employment and rational use of emigrants' home remittances

- efforts to utilise experience of returning migrants in economic development of home country.

\section{Income maintenance for persons out of work}

- general strengthening of unemployment benefit systems

- temporary wage guarantees for workers leaving declining areas or sectors

- preferential treatment of disadvantaged groups

- easing of access to early retirement for older workers meeting difficulties in the labour market

- promoting acceptance of technological and other structural change by severance pay arrangements for redundant workers. 


\section{Policy Measures in Current Use}

\section{Creating Employment}

One of the significant tendencies in the current recession has been the relatively slight emphasis on traditional public works projects for emergency employment or relief jobs. Appropriations for "public works" are nevertheless major budget items and have generally been increased (if not fully used for reasons of budgetary constraint), but they have been mainly looked upon as investments to achieve specific medium-term objectives in the public sector rather than as a means to reduce unemployment in the short run. (Recently, however, increased expenditures for housing and public works have been projected to reduce unemployment in the construction trade.)

Increasing attention has been given in recent years to creating jobs for the unemployed in public agencies, and governments have increasingly assisted non-profit/local groups which create jobs by serving useful social needs. The United States has made the most extensive use of public service employment; a Comprehensive Employment and Training Act of 1974 aims at raising the number of such jobs from 170,000 to 500,000 . Other countries have used this approach on a smaller scale. The Netherlands has a temporary programme to provide employment in government service for people under 45 who have been out of work for six months or more and for people over 45 , even if they have been unemployed for less than four months. New Zealand has extended its special Government Work Scheme to create employment for both sexes in a wide range of occupations in Government departments. Sweden is reinforcing its existing programme for sheltered employment in the public service for "white collar" workers.

Financial assistance to non-profit institutions and groups of unemployed persons is a relatively new development. The Local Initiatives Programme in Canada (see OECD Observer No 75 May-June 1975 page 14) is a direct job-creation programme that allocates federal funds to community projects initiated and implemented by unemployed groups during periods of high seasonal unemployment. A Community Employment Programme is also planned with the objective of improving employment opportunities for individuals having a history of employment difficulties. A Community Industry Scheme and Job Creation Programme exist in the United Kingdom. The former was initiated in 1974 and subsequently expanded to put hard-to-employ young people to work on projects of social or environmental value. The Manpower Services Commission has been allocated $£ 70$ million for a Job Creation Programme which supports projects submitted by local authorities, voluntary bodies, and other organisations.

Public expenditure is also being used to create jobs in the private sector, the aim increasingly being to enhance the international competitive position. Financial incentives include: private investment grants, low rates of interest, accelerated or straight depreciation allowances and rebates on taxes. The Netherlands, for instance, is contemplating a subsidy scheme to replace investment allowances or ensure that such allowances actually reduce labour costs. Sweden has put great emphasis on support for stock-piling of production in sectors of vital interest for employment (see page 31) and makes both grants and state guaranteed loans available. Spain has a wide range of measures to create new jobs in key sectors including investment subsidies, tax incentives and administrative facilities for setting up or expanding firms. Switzerland has laun- ched an extensive programme of public investments and has improved export guarantees.

Financial incentives for regional development involve job creation. The Regional Employment Premium in the United Kingdom designed to reduce the disparities in unemployment rates between development and other areas is directly linked to the number of jobs created while Regional Development Grants under the Industry Act are indirectly linked to job creation. In countries such as France and Ireland investment subsidies are conditional on the number of jobs created and maintained. In Japan grants are given to employers in designated less-developed areas to reduce urban congestion providing they also increase capacity and add more workers.

Tentative experimentation with the use of wage subsidies for job creation in the special circumstances of the present recession has been reported by a number of countries. In Germany during the first half of 1975, the Federal Labour Institute paid a wage subsidy equal to 60 per cent of gross wages over a period of six months to firms engaging additional permanent employees from the ranks of the unemployed in areas with above average unemployment. The Premium Employment Programme in Ireland provides a subsidy of $£ 12$ per week per eligible employee from mid-1975 until the end of March 1976, to be reduced thereafter to $£ 6$ until the termination of the scheme in mid-1976 and payable for the full-time employment of persons previously receiving unemployment benefits and registered for employment. Similarly in France an incentive bonus of F500 per job created is paid for six months between June and November 1975 to employers hiring, under an indefinite or one-year contract, certain categories of unemployed persons for additional jobs or to replace retirees.

In several countries experimental programmes have been developed in recent years to promote the employment of special groups. Spain gives disadvantaged workers, including older workers, preferential treatment by fully or partially remitting social security contributions. Financial incentives and assistance are given to promote the employment of new and inexperienced workers in Austria and Finland, and of both inexperienced and older workers in Germany. Sweden provides a 75 per cent wage subsidy to local authorities which train employees and at the same time employ a jobless person - preferably under 25-as a replacement for the trainee. For young people between 16 and 25 years of age, France in mid-1975 introduced subsidies for an employmenttraining scheme: by contractual agreements with employers, young workers are guaranteed a job and vocational training for a minimum of six months. The United Kingdom provides a recruitment subsidy to encourage employers to give preference to young people who have recently left school.

Finally, countries generally have tried to strengthen their employment services so that such extra duties as processing unemployment benefit claims will not interfere with the function of matching workers to jobs.

\section{Maintaining Job Attachments and Employment}

The newest emphasis in current national employment policy has been to maintain the individual worker's attachment to his job or 

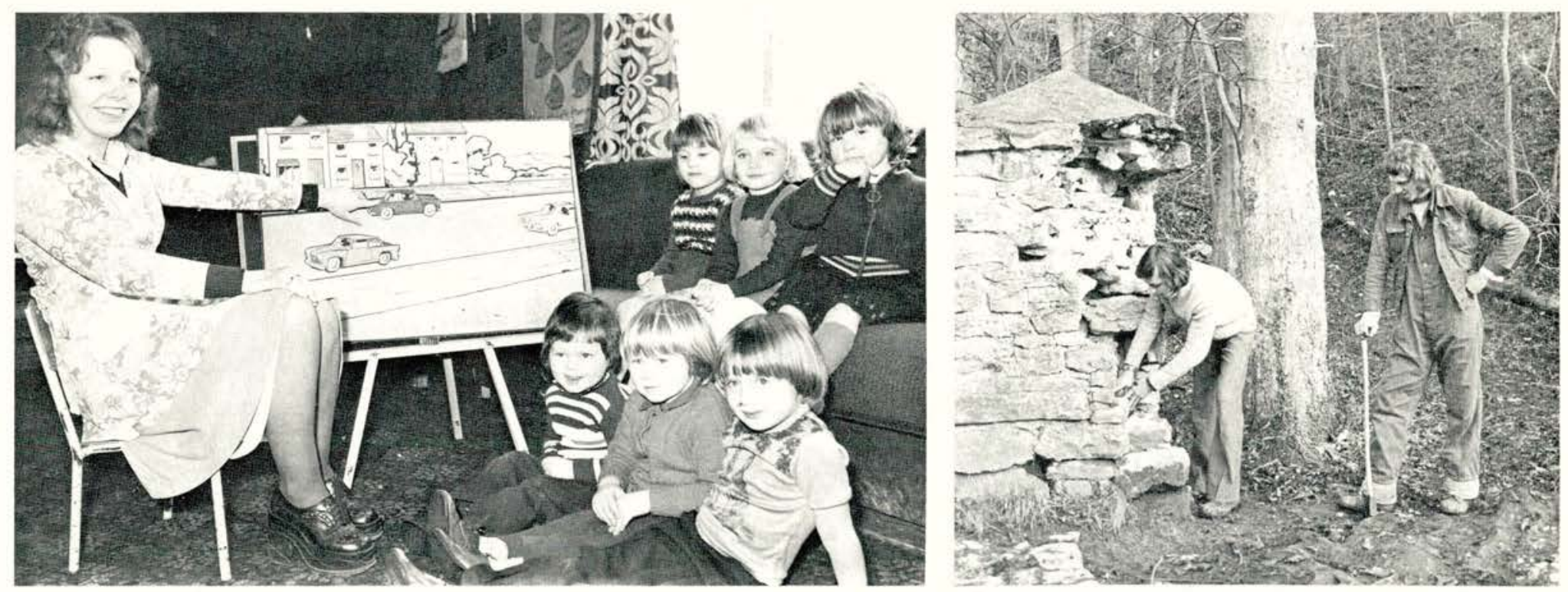

New kinds of job creation: Under a recently instituted $£ 70$ million job creation programme the U.K. Manpower Services Commission provides jobs of social value for the unemployed, particularly young people. To left: teaching pedestrian behaviour and safety to children in Cleveland County. To right: making repairs on a nature trail in Clwyd, Wales.

enterprise, an effort which also involves attempts to maintain the existence of firms.

The means used have ranged from legal requirements to exhortation with the aim of providing notice and time for consultations when redundancies are in the offing and thus to minimise dismissals. Greece for example has put legal restrictions on the percentage of a firm's labour force which can be made redundant, a percentage which varies according to the economic situation and size of the firm. In the tourist industries grants are made to firms to enable them to maintain their labour force. One of the preferred solutions in other countries has been to facilitate work-sharing through reduced hours. The major instrument used is the indirect subsidy to employers, generally through provision of benefits to workers who are working less than a normal number of hours.

These benefits, often referred to as benefits for "partial unemployment", have been quantitatively significant but their incomemaintenance aspects are secondary to their essential purpose in the present conjunctural situation: to minimise dismissals and loss of job attachment.

What is new is not the instrument itself but its widespread adoption in additional countries, its enlarged dimensions, and its results in terms of curbing the rise in the numbers of wholly unemployed. Germany, France, Belgium, Italy and Luxembourg are instances of this approach to work-sharing. The national schemes have mostly taken the form of benefits for those working less than a standard number of hours per week. In Japan, employers who implement systems of non-duty allowances during temporary layoffs can be granted a subsidy to cover a part of the allowance.

A second major and concurrent approach has been to keep enterprises in existence through various types of governmental intervention. Several countries have taken action to improve the liquidity position of enterprises through budgetary measures (Canada, France, New Zealand, and the United Kingdom). Loans have been provided in Japan, mainly for medium and small enterprises, and some countries have made loans on an ad hoc basis (France, Sweden, and the United Kingdom) or through participation in shares, often to large enterprises considered crucial for national prestige, defence or the survival of a community or to firms indirectly supporting employment through a network of subcontractors. In other cases structural adaptation may provide the rationale.
Other modes of governmental intervention at the individual firm level are efforts in Ireland and the Netherlands to find new enterprises or new management to take over industrial capacity which otherwise would close down. This may be combined with special financial incentives and assistance for retraining or with government contracts for initial orders. An innovation in the Netherlands has been for the government temporarily to take over the management of a bankrupt enterprise until personnel have been absorbed elsewhere. Another new approach has been in the United Kingdom where firms can be given assistance through the Temporary Employment Subsidy Scheme so that they can defer redundancies and keep their labour force together. A few governments have preferred to aid enterprises by supporting the demand for their output rather than providing help with costs (e.g. bulk purchase orders in Sweden, advanced orders in Finland for papermaking machinery).

Governments have given some policy emphasis to facilitating the transfer of individuals from passive and costly unemployment status to constructive alternatives. There is growing recognition of the advantages of transforming involuntary unemployment into voluntary retirement not only in recession but also at times of normal economic activity.

To facilitate a shift from unemployment to retirement status, some countries have introduced arrangements which permit unemployed people to withdraw from the labour force and obtain pre-retirement pensions when their unemployment benefit entitlement is exhausted, or after a fixed period of unemployment or after a given age. Belgium, Finland, France and Spain are instances where this type of approach has been adopted.

In line with the increasingly popular notion of flexibility of working life, employees have the right to extensive compensation for expenses and loss of pay if they pursue their studies under a German law of 1969 and a French law of 1971 (up to two per cent of a firm's labour force). Belgium, Italy, Japan and Sweden also give workers the right to paid absence for educational leave under laws passed between 1973 and 1975 .

Training the unemployed is a traditional measure, but the recognition in principle and in practice of its potentialities for counter-cyclical purposes is a more recent development, although in Sweden the Labour Market Training programme of the National Labour Market Board has been used for this purpose for some time. 
Appropriations for training were increased in a number of countries in 1974-75; contingency plans were developed in some (as in Norway) and various new training schemes introduced for the unemployed with a special emphasis on youth.

In the United States training for the unemployed has played a central role for more than a decade with special emphasis on disadvantaged groups. In its new "delivery system", block grants may be used at the discretion of State and local authorities to provide comprehensive manpower services including classroom instruction, institutional and on-the-job training.

\section{Restricting Labour Supply}

Changes resulting in a reduction of labour supply may have been occasioned not solely by economic circumstances but also by social attitudes. Australia for instance has noted an acceleration of long-term trends towards lengthier periods of initial education.

Similarly the restrictions on immigration in many of the more developed Member countries were motivated by both economic and social considerations and were introduced in a number of countries prior to the onset of the recession but were subsequently reinforced with the decline in the demand for labour.

Yet for reasons of social policy, the outflow to home countries has been relatively small compared to the exodus at the time of the recession of 1966-1967. Further there is a consensus that in the medium term there will be a continuing need for workers; the problem is one of balance and adaptation.

\section{Income Maintenance for the Unemployed}

To offset income losses occasioned by the severity of the current recession, Member countries have taken various initiatives to modify their income-support systems for the unemployed.

Existing benefit schemes, which came into play automatically with rising unemployment, have proved a major policy instrument for substantially offsetting wage losses and easing personal hard- ships as governments generally pursued deflationary demandmanagement policies. These systems essentially were designed for short-term or frictional unemployment and for periods of relatively minor lapses from full employment. The depth and duration of the current recession has led to widespread modifications particularly in benefit levels, duration, scope of coverage, and differential treatment of special groups.

Benefit levels have generally been substantially raised to compensate for inflationary rises in the cost of living, with provision in some countries for periodic review (e.g. the United Kingdom) and in others for indexation (e.g. Germany, Belgium, Italy). Changes in duration of benefits, eligibility provisions, and scope of coverage, usually by legislation or regulations, whether temporary or indefinite, are too numerous to detail.

Only a few countries have experimented with "trigger" devices for automatic extension or entitlement to benefits. In the United States, by legislation with a cut-off date, duration is automatically extended when the State or national rate exceeds four per cent for three consecutive months or averages four per cent for thirteen consecutive weeks in a State. Coverage is extended if, for three months, national unemployment exceeds six per cent or local unemployment exceeds six and a half per cent. In Japan, benefit duration is extended in certain circumstances or triggered automatically if unemployment exceeds four per cent for more than four consecutive months. In Canada, the Government contribution is based on an eight year monthly moving average of unemployment rates.

Recent changes in unemployment benefit programmes have been introduced expressly to provide income maintenance for special groups or have been of particular advantage to them. Measures in Austria, Finland and Norway are intended to have direct applicability to older unemployed workers. The 1974 Employment Insurance Law in Japan varies duration of benefits with age and employability rather than with length of employment. In France, the new Interim Supplementary allowances for workers whose posts are eliminated for economic reasons discriminate in favour of older workers with respect to benefits and duration and treat redundant workers as a special disadvantaged group.

\section{Some Indications for the Future}

\section{Reflections by Ministers as to Necessary Action ${ }^{(1)}$}

\section{Measures to Stimulate and Create Employment}

\section{Ingemund Bengtsson, Minister of Labour, Sweden, Vice Chairman of the Meeting.}

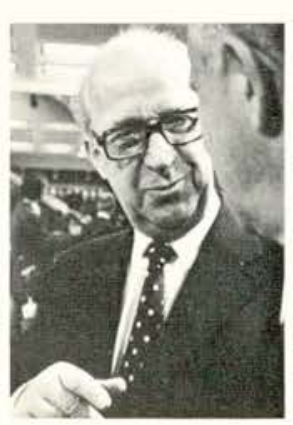

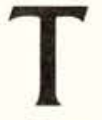

here are sinister signs in the world of an incipient resignation in the face of the unemploymentinflation dilemma. We actually hear sometimes that it does not matter too much if a certain proportion of the population is unemployed, provided their incomes are maintained at a level close to normal by insurance benefits and the like.

We should not accept such thinking. We should accept neither the big losses in potential production and of national income, nor the even greater losses of human and social values involved in unemployment. We must recognise work as a basis of self-esteem and human dignity.

One reason why unemployment is not the effective means against inflation that some theorists once believed is that nowadays it first and foremost hits those groups which have the least influence upon the wage-price spiral: groups with a weak position in the labour market; young people and old, housewives trying to resume gainful employment, people in remote or under-developed areas.

(1) Excerpts from presentations by the three vice-chairmen of the Meeting on Future Employment Prospects and Policies. 
There are not only such social but also economic reasons for the view that a policy which creates unemployment is not applicable as a weapon against inflation. True, a contraction of activities would to some extent make producers more cautious about prices, but, on the other hand, average cost per unit will automatically increase because overhead costs have to be divided among a lower number of units produced. Enterprises will try to compensate for these cost increases and losses by a policy of high prices, either immediately (those in more or less monopolistic positions) or as soon as the economy starts growing again.

We are also told that we must allow profits to be restored so that enterprises can acquire capital for expansion after those meagre periods of restraint. I do not know how one could prevent such additional profits from provoking a new wage-price-profits race. If we carry out a stabilizing policy that keeps enterprises utilising their capacity steadily all the time-and not the stop-go policy-then there will be a better chance of restoring full employment and avoiding the inflationary squirrel-wheel.

General influences upon the economic temperature cannot save us either from inflation or from unemployment; we must have a new strategy with many more "selective manpower adaptation and employment creation measures".

We find, for example, that the old idea of using adult training and retraining as a short-term instrument of employment policy is now making real progress. New systems of paid educational leave and recurrent education in important countries enhance the possibilities of acting rapidly in this way against employment disturbances. The expenditure for training courses-and thus their inflationary effects-are not very high. But anti-inflationary effects are to be expected from a better supply of trained personnel when and where the demand for labour starts growing - provided such "labour market training" concerns all types and levels of qualifications; there is not much use in only helping some low-skilled persons to out-complete some other ones.

In several country reports we find, however, that even more directly antiinflationary methods of employment creation are being tried on an increasing scale. Earlier regional development programmes, for example, used to be concentrated solely on investment incentives. More modern schemes also combine this with subsidies directly based upon the number of employment opportunities actually pro- vided by the recipients. Sometimes the grants are given only for net additions to a firm's work force.

The basic idea underlying this type of employment policy is that we draw a first line of defence against unemployment inside each enterprise. Furthermore, we use measures which make employers act in their own interest in a way which corresponds to the aims of the employment policy.

Every employer constantly has to make a choice between two alternatives. One alternative is to keep employment high (by production for stock or for immediate selling at relatively low prices). The other alternative is to reduce production and consequently also employment in order to keep prices high.

Decisions in favour of the first alternative are hampered by huge barriers of costs and risks, which appear particularly when employment is to be increased (e.g.

the training of new employees who will perhaps soon leave the firm). Here, therefore, is a strategic point, at which we should apply employment-promoting incentives, counterbalancing these costs and risks.

It is not only a social gain but also a gain for public finances when a person is moved from the unemployment queue into paid work, thus becoming a taxpayer. Growing rates of both unemployment benefits and general taxes enhance the impact of this anti-inflationary element in employment promotion.

There is thus a need for further actions in the OECD area to fight unemployment, and there is a need to coordinate these actions. There is also a need to understand that not only new methods but also new orders of magnitude in our actions are needed to avert what threatens to become a disaster to Western communities.

\title{
Equity in Employment
}

\author{
the Hon. Robert Andras, Minister of Manpower and \\ Immigration of Canada, Vice Chairman of the Meeting.
}

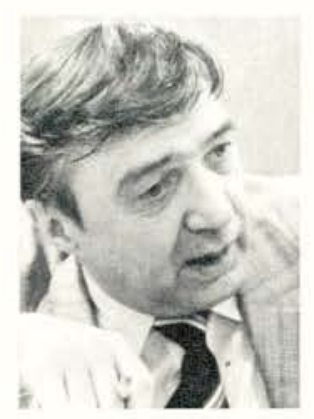

quity in employment and equity in the resulting distribution of income has and will continue to be one of the main preoccupations of our societies for many, many years. Only a few generations ago, people believed that universal public education would cure society's ills and achieve equity through providing all with more skills and income. Although that philosophy has served this purpose and served it well, Utopia has not come; the poor and the disadvantaged are still with us.

At issue are three goals which should be within the reach of all members of society:

- access to the labour market;

- the ability to find and keep jobs, and earn decent incomes; and

- the potential to pursue a self-fulfilling career path.

While the achievement of these goals is not difficult for large groups in modern societies, there are groups with special needs for whom achievement of equity in employment often poses insurmountable problems. This is especially true, for example, of those with physical or mental disabilities, and of those socially or geographically remote from the mainstream of economic activity. Still others, in varying degrees, are women, the young, and older workers, each of whom face particular and exasperating problems often reflecting an unfair evaluation of their worth, their contribution, and their potential in today's economic environment.

Looking at the inventories of manpower programmes of the member countries, I am impressed by the diversity of responses to these challenges.

There is not a country here today which has not moved dramatically forward in its manpower programmes since 1964. Most Member countries have programmes which urge employers to remove artificial barriers, and change traditional hiring patterns, for all of those who have special needs, by reason of inexperience, sex, age, or disabilities.

What is perhaps more striking than these developments is the fact that none of us seem to have overcome these problems. We must ask ourselves "why"?

Are we looking at problems so vast and so deeply rooted that, even with the best programmes and the most generous funding, we will need not a few years of effort but a major effort over the course of a generation or two? Are we trying to accomplish a task whose magnitude is vastly in excess of the funds that govern- 
ments have traditionally been able to allocate? Have we gone about the task in the right way, with enough determination, and with the most effective programmes? Are there better ways to do what we have all been trying to accomplish?

In the past, our societies mobilized their efforts behind education as the grand plan to achieve social equity. We must not foresake that commitment, but we all now know that it is not itself sufficient. The demands of today and tomorrow are that we mobilize, with a host of strategies, against those forces tending to keep many out of the mainstream of society.

We in Canada are very conscious of the problems of the disadvantaged, so much so that we are experimenting with a new thrust for which we have great hopes. In addition to rehabilitation programs, and training programs, and Local Employment Assistance programs, we have begun on an experimental basis a Commu-

nity Employment Strategy (C.E.S.). This is not a new program in the traditional sense. It is a whole new institutional approach to integrate the fragmented federal and provincial and local programs and focus the collective resources on the problems of disadvantaged in the most effective and efficient way. We feel that our C.E.S. can be a way of reaching into every corner of the country and involving the disadvantaged themselves in the planning and administration of the strategy. Although still small, and still experimental, it is one of our great hopes for the future.

In terms of the long span of human history, we are-even the most advanced of us-only the beginning miles down a long road. I would hope that, in the spirit of learning from each other, we will, each in his own way, consider how we can best mount an attack on these problems which might wipe them from the faces of our countries.

\section{Intra European Migration}

\section{Constantin Laskaris, Minister of Employment, Greece and Vice-Chairman of the Meeting}

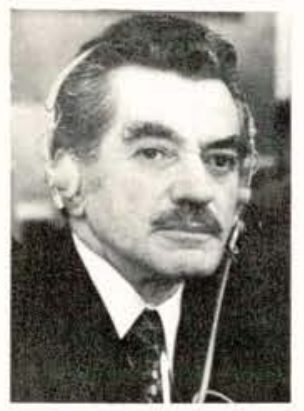

is very difficult for the emigration country to formulate a realistic and effective manpower policy without prior knowledge of the precise intentions of host countries towards foreign workers. These workers, who occupy an important position in the secondary sector of immigration countries, have with their labour contributed to the economic growth of these countries and to the maintenance of full employment.

The scale of the problem is clear; migration in Western Europe involves 13 million people (including members of workers' families). This means that, on average, foreigners account for 6 per cent of the total population of immigration countries. The proportion varies considerably from one country to another: 27 per cent in Luxembourg, 16.7 per cent in Switzerland, 8 per cent in Belgium, 7.7 per cent in France, 6.4 per cent in Germany and 1.1 per cent in Denmark.

The two groups of countries concerned now realize that the problem can only be solved by consultation and jointly determined action; this demonstrates that there is a desire for solidarity and cooperation at European level. If the immigration countries do not adopt appropriate policies regarding foreign workers, they may cause difficulties and even crises for the economies of the emigration countries. Most of the latter, however, represent markets for host country exports. It goes without saying that, quite apart from any humanitarian or moral issues, the logic of contemporary economic relationships dictates that no one can have any interest in undermining his own customers.

Up to now, despite the recession, there have been no massive returns of workers to the main emigration countries. In Greece, for example, homeward flows have so far been very moderate (some 34,000 in 1975) and, provided the rate does not suddenly accelerate, we hope that our economy will be able to cope with them. I said "provided the rate does not accelerate suddenly" because there are some grounds for fearing an increase in homeward flows, which will raise a number of problems for our respective economies.

To avoid any large-scale and disorderly homeward flow of workers, close cooperation should be established between host and home countries. Such cooperation might take two forms. First, special machinery might be introduced to help the returning migrant, from the moment. he is given notice until his actual arrival back home. Secondly, since the various stages in the process of repatriating migrants and reintegrating them in working life raise financial problems which can hardly be ignored, we ought to examine the possibility of establishing a special fund to help the countries concerned cope with the situation.

It may be that the heavy intra-European migratory flows we have experienced up to now will not recur on the same scale. If this hypothesis were to be confirmed by a detailed study, we would have to shift the whole direction of our thinking. Demographic and economic projections show that some of our countries will always have a considerable supply of manpower and that others will need to draw upon it to operate their productive and financial systems at full capacity. We shall therefore have to find new ways of handling this - a new clearing-house for available manpower and for those who wish to use it. One answer might be to transfer capital rather than labour. But is this the only answer? I am not sure. Is it the best answer? I am still less sure.

One other problem which is now affecting some emigration countries and immigration countries as well is the new tendency for part of the work force to shy away from manual labour. In Greece, we have seen this over the last two or three years, and it is also of concern to various other Western European countries. It is liable to represent a serious brake on expansion in the host countries, especially once a certain number of foreign workers have returned home. Once back in their own country, these same workers may have a similar attitude and set themselves up as "small businessmen" rather than work for a wage in industry. The problem here is similar both for host and home countries. Who, in the host country, will take on the various kinds of manual work done by migrants once the latter have gone, if its own nationals have no incentive to do such work? Furthermore, how can the home countries ignore the problem and not take every possible step to direct repatriated workers towards the kind of manual work for which they are already trained? This is a problem on which we must all reflect. In the first place, we must find a new economic and social status for manual work; secondly, there will be a need for greater coordination between education and employment. 
Because of frequent statistical revisions, figures for population and employment may be noticeably different from those published in the preceding "OECD Member Countries".

\begin{tabular}{|c|c|c|c|c|c|}
\hline $\begin{array}{l}\text { Because of frequent statistical } \\
\text { revisions, figures for population } \\
\text { and employment may be noti- } \\
\text { ceably different from those } \\
\text { published in the preceding } \\
\text { "OECD Member Countries". }\end{array}$ & $\begin{array}{c}\text { AREA } \\
1,000 \text { sq. } \mathrm{km}\end{array}$ & $\begin{array}{l}\text { AGRICUL- } \\
\text { TURAL } \\
\text { AREA } \\
1,000 \text { sq. km }\end{array}$ & $\begin{array}{l}\text { TILLAGE } \\
1,000 \mathrm{sq} . \mathrm{km}\end{array}$ & $\begin{array}{l}\text { POPULATION } \\
\text { thousands }\end{array}$ & $\begin{array}{l}\text { INHABI- } \\
\text { TANTS } \\
\text { per sq. km }\end{array}$ \\
\hline AUSTRALIA & $7,686.8$ & $\begin{array}{c}4,978.9 \\
1973\end{array}$ & $\underset{1973}{451.9}$ & 13,338 & 2 \\
\hline AUSTRIA & 83.8 & 37.9 & 16.1 & 7,545 & 90 \\
\hline BELGIUM & 30.5 & $\begin{array}{l}15.7 \\
1973\end{array}$ & $\begin{array}{l}8.3 \\
1973\end{array}$ & 9,772 & 320 \\
\hline CANADA & $9,976.1$ & $\begin{array}{c}686.7 \\
1971\end{array}$ & $\begin{array}{c}437.7 \\
\end{array}$ & 22,479 & 2 \\
\hline DENMARK & 43.1 & 29.5 & 26.6 & 5,045 & 117 \\
\hline FINLAND & 337.0 & 28.6 & 27.0 & 4,688 & 14 \\
\hline FRANCE & 549.1 & 324.8 & 189.0 & 52,492 & 96 \\
\hline GERMANY & 248.5 & 133.4 & 80.8 & 62,054 & 250 \\
\hline GRE & 132.0 & 87.6 & 35.2 & 8,962 & 68 \\
\hline |CE| & 103.0 & 23.8 & - & 215 & 2 \\
\hline |REL & 70.3 & $\begin{array}{l}48.4 \\
1973 \\
\end{array}$ & $\begin{array}{c}12.4 \\
1973\end{array}$ & 3,086 & 44 \\
\hline ITA & 301.2 & $\begin{array}{c}174.8 \\
1973\end{array}$ & $\frac{122.3}{1973}$ & 55,361 & 184 \\
\hline JAPAN & 372.3 & $\begin{array}{l}58.8 \\
1973\end{array}$ & $\begin{array}{l}56.5 \\
1973\end{array}$ & 109,710 & 295 \\
\hline LUXEMBOURG & 2.6 & 1.3 & 0.6 & 357 & 137 \\
\hline NETHERLANDS & 36.9 & 20.9 & 8.4 & 13,545 & 367 \\
\hline NEW ZEALAND & 268.7 & $\begin{array}{c}142.3 \\
1973\end{array}$ & $\begin{array}{l}9.9 \\
1973\end{array}$ & 3,045 & 11 \\
\hline NORWAY & 323.9 & 9.0 & 7.9 & 3,985 & 12 \\
\hline PORTUGAL & 91.6 & $\begin{array}{r}(49.0) \\
1972\end{array}$ & $\begin{array}{c}(43.7) \\
1972\end{array}$ & 8,782 & 96 \\
\hline SPAIN & 504.8 & 320.8 & 208.8 & 34,956 & 69 \\
\hline SWEDEN & 450.0 & 37.3 & 30.3 & 8,157 & 18 \\
\hline SWITZERLAND & 41.3 & 20.2 & $\begin{array}{r}3.8 \\
1973\end{array}$ & 6,443 & 156 \\
\hline TURKEY & 780.6 & 476.5 & 279.0 & 39,066 & 50 \\
\hline UNITED KINGDOM & 244.0 & 186.4 & 71.6 & 56,068 & 230 \\
\hline UNITED STATES & $9,363.4$ & $4,353.3$ & $1,910.5$ & 211,894 & 23 \\
\hline
\end{tabular}




\begin{tabular}{|c|c|c|c|c|c|}
\hline $\begin{array}{l}\text { TOTAL } \\
\text { INCREASE }\end{array}$ & CRUDE BIRTH & TOTAL CIVILIAN & & of which: & \\
\hline $\begin{array}{c}\text { annual average } \\
1964-1974 \\
\%\end{array}$ & & & $\begin{array}{c}\text { AGRICULTURE, } \\
\text { FORESTRY } \\
\text { AND FISHING } \\
\%\end{array}$ & $\begin{array}{c}\text { INDUSTRY } \\
\%\end{array}$ & $\begin{array}{c}\text { OTHER } \\
\%\end{array}$ \\
\hline 1.8 & 18.4 & 5,736 & 6.9 & 35.1 & 58.0 \\
\hline 0.4 & 12.9 & 3,010 & 13.0 & 41.0 & 46.0 \\
\hline 0.4 & 12.6 & 3,801 & 3.7 & 41.2 & 55.1 \\
\hline 1.5 & 15.4 & 9,137 & 6.3 & 31.1 & 62.6 \\
\hline 0.7 & 14.1 & 2,355 & 9.6 & 32.3 & 58.1 \\
\hline 0.3 & 13.2 & 2,220 & 16.3 & 36.1 & 47.6 \\
\hline 0.8 & 15.2 & 21,096 & 11.6 & 39.2 & 49.2 \\
\hline 0.7 & 10.1 & 25,689 & 7.3 & 47.6 & 45.1 \\
\hline 0.5 & 16.1 & $(3,170)$ & (36.2) & (27.8) & $(36.0)$ \\
\hline 1.3 & 19.5 & $\left(\begin{array}{c}9073 \\
9073\end{array}\right)$ & 15.5 & 37.8 & 46.7 \\
\hline 0.7 & 22.3 & 1,047 & 24.3 & 31.1 & 44.6 \\
\hline 0.7 & 15.9 & 18,715 & 16.6 & 44.1 & 39.3 \\
\hline 1.2 & 18.5 & 52,010 & 12.9 & 37.0 & 50.1 \\
\hline 0.8 & 11.0 & 151 & 6.4 & 49.2 & 44.4 \\
\hline 1.1 & 13.7 & 4,579 & 6.6 & 35.5 & 57.9 \\
\hline 1.6 & 19.3 & 1,180 & 12.0 & 34.7 & 53.3 \\
\hline 0.8 & 15.1 & 1,659 & 10.5 & 34.2 & 55.3 \\
\hline-0.2 & 19.2 & 3,081 & 28.2 & 33.6 & 38.2 \\
\hline 1.0 & 19.6 & 12,860 & 23.1 & 37.2 & 39.7 \\
\hline 0.6 & 13.5 & 3,962 & 6.7 & 37.0 & 56.3 \\
\hline 0.9 & 12.9 & 2,943 & 7.6 & 47.0 & 45.4 \\
\hline 2.6 & (39.6) & 14,868 & 64.1 & 14.8 & 21.1 \\
\hline 0.4 & 13.1 & 24,767 & 2.8 & 42.3 & 54.9 \\
\hline 1.0 & 14.9 & 85,936 & 4.1 & (31.1) & (64.8) \\
\hline
\end{tabular}




\begin{tabular}{|c|c|c|c|c|c|c|c|c|c|c|c|c|c|c|c|c|c|c|c|c|c|c|c|c|c|}
\hline \multicolumn{2}{|c|}{ 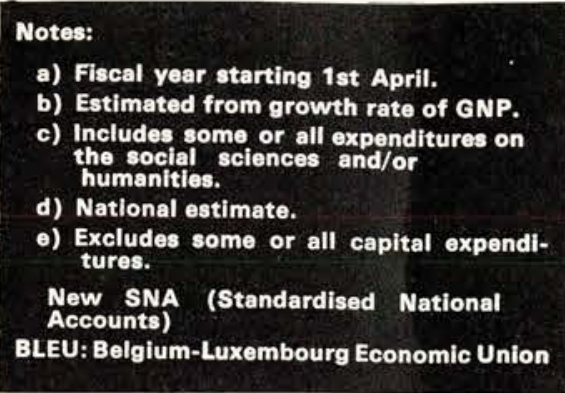 } & 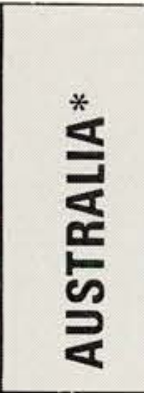 & & 竞 & 亮 & 惫 & 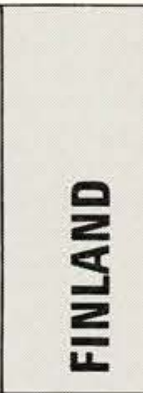 & 莺 & 离 & 恺 & 虽 & 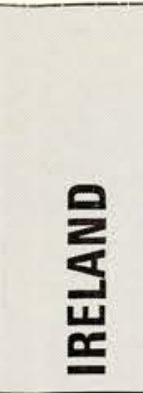 & 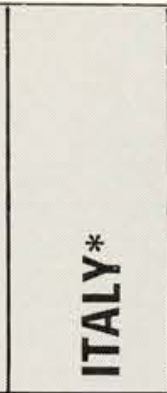 & 䒺 & 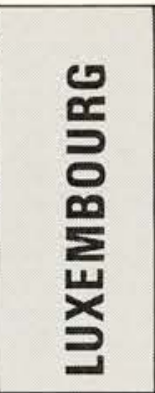 & 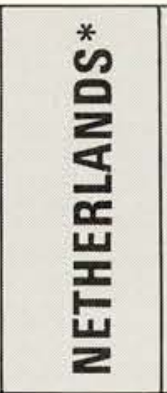 & 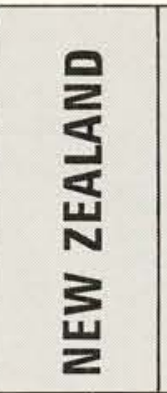 & 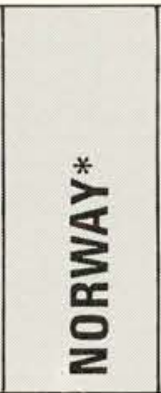 & $\begin{array}{l}\overrightarrow{\mathbb{E}} \\
\text { 总 } \\
\text { 옴 }\end{array}$ & $\frac{3}{\frac{a}{a}}$ & $\begin{array}{l}\sum_{u}^{*} \\
\text { 岂 }\end{array}$ & 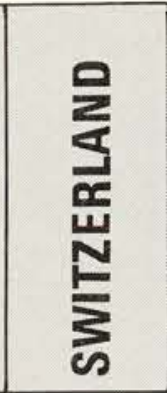 & 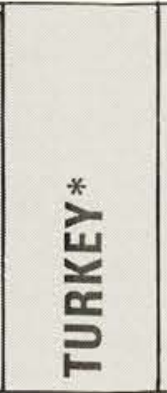 & 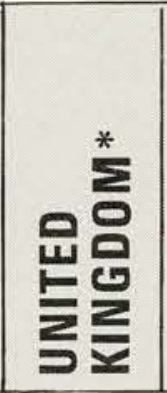 & 噼 \\
\hline \multirow{3}{*}{ 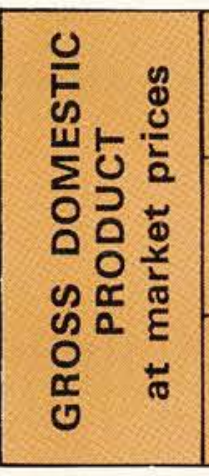 } & 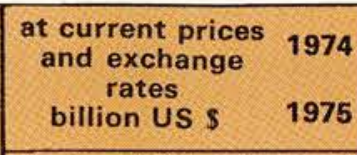 & $\begin{array}{r}78.40 \\
(83.3) \\
\end{array}$ & $\begin{array}{r}33.00 \\
(38.2) \\
\end{array}$ & $\begin{array}{r}53.42 \\
(6) \\
(64.4)\end{array}$ & $\begin{array}{r}145.30 \\
(161.3) \\
(151)\end{array}$ & $\begin{array}{r}30.40 \\
(35.6) \\
\end{array}$ & $\begin{array}{r}22.03 \\
(26.6)\end{array}$ & \begin{tabular}{|l}
266.10 \\
$(331.4)$
\end{tabular} & $\begin{array}{c}384.53 \\
(b) \\
(429.7)\end{array}$ & $\begin{array}{l}19.26 \\
(b) \\
(21.3)\end{array}$ & $\begin{array}{l}1.35 \\
(b) \\
(1.2)\end{array}$ & $\begin{array}{l}6.73 \\
(b) \\
(8.0)\end{array}$ & $\begin{array}{l}149.81 \\
(171.9)\end{array}$ & $\begin{array}{l}453.31 \\
\left(\begin{array}{l}(b) \\
(484.6)\end{array}\right.\end{array}$ & $\begin{array}{l}2.13 \\
(2.2)\end{array}$ & $\begin{array}{r}69.18 \\
(81.5)\end{array}$ & $\begin{array}{r}13.52 \\
(13.2)\end{array}$ & $\begin{array}{l}23.30 \\
(28.6)\end{array}$ & $\underset{1973}{11.13}$ & $\begin{array}{c}73.66 \\
\text { (b) } \\
(86.0)\end{array}$ & \begin{tabular}{|c|}
56.10 \\
$(67.3)$ \\
\end{tabular} & $\begin{array}{r}44.90 \\
(53.6) \\
\end{array}$ & \begin{tabular}{c|}
29.43 \\
$(36.5)$ \\
\end{tabular} & \begin{tabular}{|c|}
188.99 \\
$(227.0)$ \\
\end{tabular} & $\begin{array}{l}1,398.00 \\
(1,47.7) \\
(1,47.7)\end{array}$ \\
\hline & 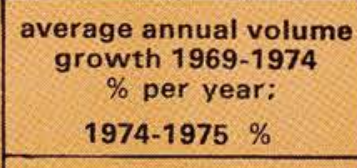 & $\begin{array}{l}4.21 \\
\text { (b) } \\
(1.75) \\
\end{array}$ & $\begin{array}{l}5.92 \\
(-3) \\
\end{array}$ & $\begin{aligned} & 5.25 \\
&(-6) \\
&(-2.50) \\
&\end{aligned}$ & $\begin{array}{l}4.81 \\
(b) \\
(-1) \\
\end{array}$ & $\begin{array}{c}2.91 \\
(-1.50 \\
\end{array}$ & $\begin{array}{l}5.64 \\
(-1) \\
\end{array}$ & $\begin{array}{l}5.28 \\
(-2) \\
\end{array}$ & $\begin{array}{c}3.56 \\
(b) \\
(-3.75)\end{array}$ & $\begin{array}{c}5.61 \\
(6) \\
(-0.75)\end{array}$ & $\begin{array}{c}6.18 \\
(b) \\
(-3.50) \\
\end{array}$ & $\begin{array}{c}3.31 \\
\text { (b) } \\
(-3.75) \\
\end{array}$ & $\begin{array}{c}3.86 \\
(-4.50) \\
\end{array}$ & $\begin{array}{l}6.95 \\
(1.25) \\
(1.25) \\
\end{array}$ & $\begin{array}{c}4.14 \\
(-3.50) \\
\end{array}$ & $\begin{array}{l}4.54 \\
(-2) \\
\end{array}$ & $\begin{array}{r}4.41 \\
\text { (1) }\end{array}$ & $\begin{array}{l}4.17 \\
\text { (4) }\end{array}$ & \begin{tabular}{c|c}
6.41 \\
$1968-73$
\end{tabular} & $\begin{array}{l}6.44 \\
(\text { b) } \\
(-1)\end{array}$ & $\begin{array}{c}3.18 \\
(0)\end{array}$ & $\begin{array}{r}3.53 \\
(-3.7) \\
\end{array}$ & $\begin{array}{l}6.80 \\
(8.1)\end{array}$ & $\begin{array}{r}2.69 \\
(-2.25) \\
\end{array}$ & $\begin{array}{l}2.64 \\
(b) \\
(-3)\end{array}$ \\
\hline & $\begin{array}{l}\text { per capita at current } \\
\text { prices and exchange } \\
\text { rates US } \$ \text { S }\end{array}$ & 5,880 & 4,370 & 5,470 & 6,460 & 6,030 & 4,710 & 5,060 & 6,200 & 2,150 & 6,280 & 2,180 & 2,710 & 4,130 & 5,950 & 5,110 & 4,440 & 5,850 & $\begin{array}{r}1,300 \\
1973\end{array}$ & 2,100 & 6,880 & 6,970 & 750 & $\mathbf{3 , 3 7 0}$ & 6,600 \\
\hline \multirow{2}{*}{ 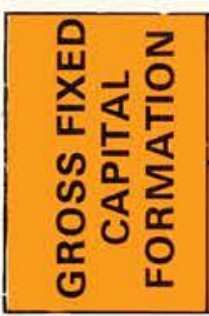 } & $\begin{array}{l}\text { total } \\
\% \text { of GDP } \\
\text { at current prices }\end{array}$ & 19.6 & 28.0 & 22.3 & 23.2 & 21.9 & 29.0 & 25.1 & 22.5 & 21.4 & 32.0 & -24.9 & 23.4 & 34.3 & 25.5 & 22.2 & $\begin{array}{l}\text { (a) } \\
21.4 \\
1973\end{array}$ & 32.1 & $\begin{array}{l}20.1 \\
1973\end{array}$ & $\begin{array}{l}21.7 \\
1973\end{array}$ & 22.0 & 26.7 & $\begin{array}{l}16.9 \\
1973\end{array}$ & 20.1 & 17.5 \\
\hline & 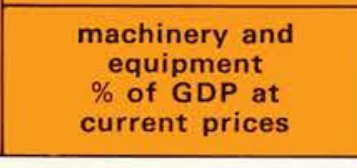 & 9.89 & $\begin{array}{l}10.63 \\
1973\end{array}$ & 8.16 & 8.21 & 9.09 & 10.66 & ${ }_{1972}^{11.42}$ & 9.78 & 8.74 & 9.86 & $\begin{array}{l}9.72 \\
9973\end{array}$ & 10.53 & $\mid 12.47$ & 8.59 & 9.37 & .. & 12.04 & $\begin{array}{l}8.60 \\
1973\end{array}$ & $\begin{array}{r}10.21 \\
{ }_{1972}\end{array}$ & 9.16 & 9.25 & $\begin{array}{l}7.77 \\
1973\end{array}$ & 8.82 & 6.78 \\
\hline \multirow{2}{*}{ 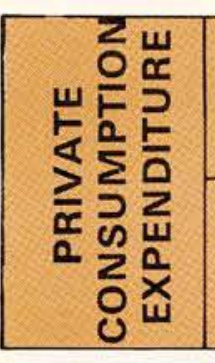 } & $\begin{array}{l}\% \text { of GDP } \\
\text { at current prices }\end{array}$ & 58.3 & 53.9 & 59.6 & 55.5 & 56.1 & 49.2 & 61.6 & 53.5 & 72.7 & 65.0 & 70.7 & 65.9 & 52.6 & 53.4 & 56.0 & $\begin{array}{l}\text { (a) } \\
59.2 \\
1973\end{array}$ & 52.3 & $\begin{array}{l}72.3 \\
1973\end{array}$ & $\begin{array}{l}66.8 \\
1973\end{array}$ & 53.0 & 61.7 & $\begin{array}{l}72.2 \\
1972\end{array}$ & 63.5 & 62.9 \\
\hline & $\begin{array}{l}\text { US S p per capita } \\
\text { at current prices } \\
\text { and exchange rates }\end{array}$ & $\mathbf{3 , 4 3 0}$ & 2,360 & 3,260 & 3,590 & 3,380 & 2,320 & 3,120 & 3,310 & 1,560 & 4,080 & 1,540 & 1,780 & 2,180 & 3,180 & 2,860 & $\begin{array}{c}2,350 \\
1973\end{array}$ & 3,060 & $\begin{array}{l}940 \\
{ }_{1973}\end{array}$ & $\begin{array}{c}1,170 \\
1973\end{array}$ & 3,650 & 4,300 & $\begin{array}{l}310 \\
1972\end{array}$ & 2,140 & 4,150 \\
\hline \multirow{2}{*}{ 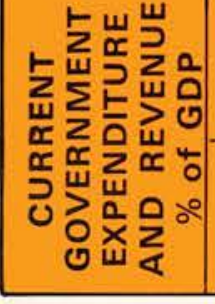 } & current expenditure & $\begin{array}{l}23.3 \\
1993-74\end{array}$ & 31.0 & 36.4 & 34.7 & 40.0 & 30.3 & $\begin{array}{l}33.8 \\
1973\end{array}$ & 37.5 & 22.8 & $\begin{array}{l}24.9 \\
1968\end{array}$ & $\begin{array}{l}34.8 \\
1973\end{array}$ & 34.4 & $\begin{array}{l}15.7 \\
1973\end{array}$ & 32.9 & 46.4 & $\cdots$ & 40.9 & $\begin{array}{l}20.1 \\
1973\end{array}$ & $\begin{array}{l}20.1 \\
1972\end{array}$ & 44.4 & $\begin{array}{l}22.2 \\
1969\end{array}$ & $\begin{array}{l}\mathbf{1 8 . 3} \\
1972\end{array}$ & $\begin{array}{l}35.3 \\
1973 .\end{array}$ & $\begin{array}{l}29.6 \\
1973\end{array}$ \\
\hline & current revenue & $\begin{array}{c}28.9 \\
1973-74\end{array}$ & 38.4 & 37.9 & 38.6 & 47.4 & 38.7 & $\begin{array}{l}38.1 \\
1973\end{array}$ & 41.4 & 24.2 & $\begin{array}{l}33.2 \\
1968\end{array}$ & $\begin{array}{l}35.1 \\
1973 \\
\end{array}$ & 32.6 & $\begin{array}{l}23.3 \\
1973\end{array}$ & 44.3 & 51.4 & $\cdots$ & 48.5 & $\begin{array}{l}23.0 \\
1973\end{array}$ & $\begin{array}{l}23.4 \\
1972\end{array}$ & 49.4 & $\begin{array}{l}27.1 \\
{ }_{1969}\end{array}$ & $\begin{array}{l}27.5 \\
1972\end{array}$ & $\begin{array}{l}37.0 \\
1973\end{array}$ & $\begin{array}{l}30.2 \\
{ }_{1973}\end{array}$ \\
\hline \multicolumn{2}{|c|}{$\begin{array}{l}\text { NET OFFICIAL DEVELOPMENT } \\
\text { ASSISTANCE } \\
\text { to developing countries } \\
\text { and multilateral agencies } \\
\% \text { of GNP }\end{array}$} & 0.55 & 0.18 & 0.51 & 0.50 & 0.55 & 0.18 & 0.59 & 0.37 & $\cdots$ & $\cdots$ & $\cdots$ & 0.15 & 0.25 & $\cdots$ & 0.63 & 0.31 & 0.57 & -. & .. & 0.72 & 0.14 & . & 0.38 & 0.25 \\
\hline \multicolumn{2}{|c|}{ 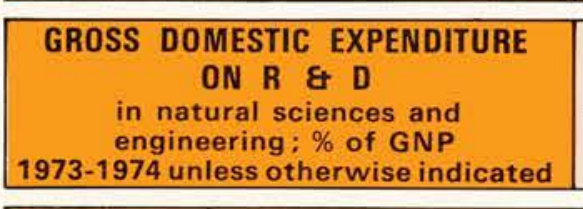 } & $\begin{array}{l}\text { (c) } \\
1.2\end{array}$ & $\begin{array}{l}\text { (c, d) } \\
1.0 \\
1972\end{array}$ & $\begin{array}{l}1.2 \\
1973 \\
1973\end{array}$ & 1.1 & 1.0 & $\begin{array}{l}\mathbf{0 . 8} \\
1973\end{array}$ & $\begin{array}{l}1.7 \\
1973\end{array}$ & $\begin{array}{l}2.0 \\
1973\end{array}$ & -. & $\begin{array}{l}0.5 \\
1973\end{array}$ & $\begin{array}{l}\mathbf{0 . 7} \\
1974\end{array}$ & . & 1.7 & $\cdots$ & 1.8 & $\begin{array}{c}0.9 \\
0.972-73\end{array}$ & $\begin{array}{l}1.1 \\
1972\end{array}$ & $\begin{array}{l}0.3 \\
1972\end{array}$ & $\begin{array}{l}\text { 0. } \\
1972\end{array}$ & $\begin{array}{l}\mathbf{1 . 6} \\
1973\end{array}$ & $\cdots$ & $\cdots$ & $\begin{array}{c}2.1 \\
1972-73\end{array}$ & 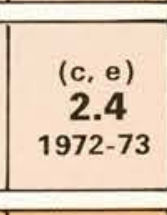 \\
\hline \multirow{2}{*}{ 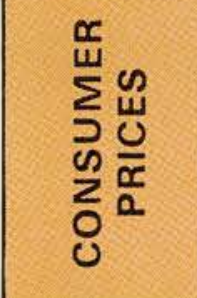 } & $\begin{array}{c}\text { increase } 1975 \\
\%\end{array}$ & 15.1 & 8.5 & 12.7 & 10.8 & 9.6 & 17.8 & 11.7 & 6.0 & 13.7 & 49.1 & 20.9 & 17.0 & 11.8 & 10.7 & 10.2 & 14.7 & 11.7 & 15.2 & 16.9 & 10.1 & 6.7 & .. & 23.4 & 7.0 \\
\hline & $\begin{array}{l}\text { average annual } \\
\text { increase e } 1970 .-1975 \\
\% \text { per vear }\end{array}$ & 10.2 & 7.3 & 8.4 & 7.3 & 9.3 & 11.7 & 8.8 & 6.1 & 12.4 & 24.7 & 13.3 & 11.3 & 11.5 & 7.2 & 8.6 & 10.2 & 8.2 & 15.1 & 12.1 & 8.0 & 7.7 & $\cdots$ & 13.0 & 6.3 \\
\hline \multicolumn{2}{|c|}{ 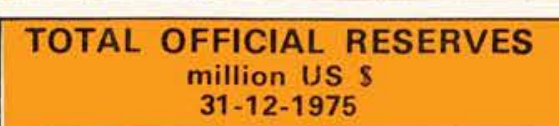 } & 3,256 & 4,439 & $\begin{array}{c}\mathbf{5 , 7 9 7} \\
\text { BLEU }\end{array}$ & 5,326 & 877 & 470 & 12,593 & $\mid 31,018$ & $\left|\begin{array}{|c|}943 \\
28.11 .75\end{array}\right|$ & 47 & 1,532 & 4,774 & 12,815 & $\begin{array}{c}5,797 \\
B L E U\end{array}$ & 7,109 & $\begin{array}{c}581 \\
28-11-75\end{array}$ & 2,237 & \begin{tabular}{|c|}
$\mathbf{1}, 485$ \\
28.11 .75
\end{tabular} & $\begin{array}{r}\mathbf{5 , 9 6 4} \\
28.11 .75\end{array}$ & 3,077 & 10,428 & $\left|\begin{array}{c}1,151 \\
28-11-75\end{array}\right|$ & 5,459 & $\mid$\begin{tabular}{|l}
15,883 \\
\end{tabular} \\
\hline
\end{tabular}


a) International transport excluded except for Canada and Turkey.

BLEU: Belgium -

Luxembourg

Economic Union

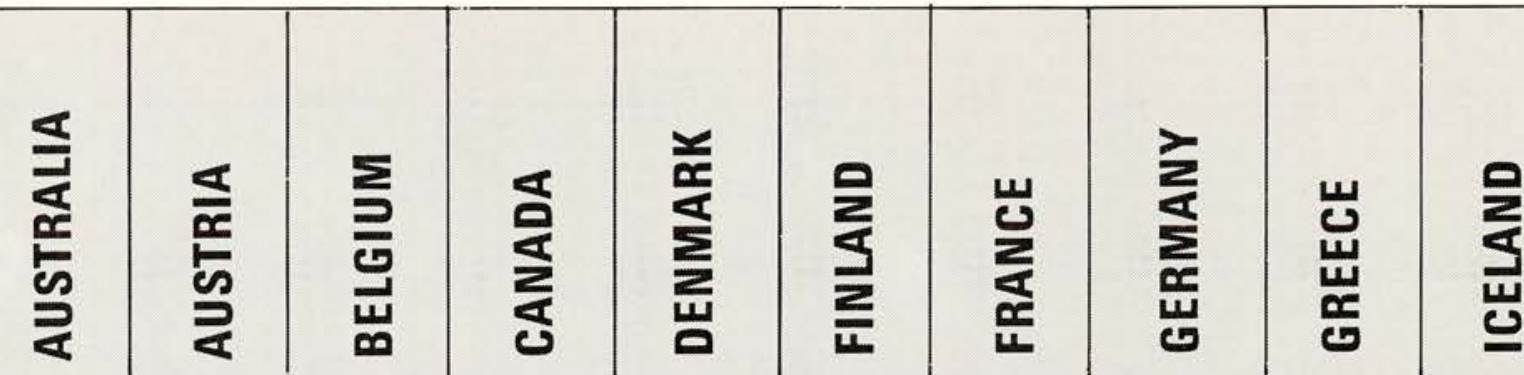

\begin{tabular}{|c|c|c|c|c|c|c|c|c|c|c|c|c|}
\hline \multirow{2}{*}{ 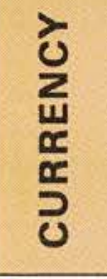 } & monetary unit & $\begin{array}{c}\text { Australian } \\
\text { Dollar }\end{array}$ & Schilling & $\begin{array}{c}\text { Belgian } \\
\text { Franc }\end{array}$ & $\begin{array}{c}\text { Canadian } \\
\text { Dollar }\end{array}$ & Krone & $\begin{array}{l}\text { Finnish } \\
\text { Mark }\end{array}$ & $\begin{array}{l}\text { French } \\
\text { Franc }\end{array}$ & $\begin{array}{l}\text { Deutsche } \\
\text { Mark }\end{array}$ & Drachma & Krona & $P$ \\
\hline & 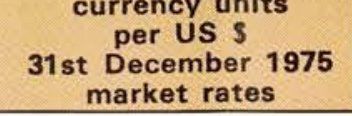 & 1.257 & 18.510 & $\begin{array}{c}39.528 \\
\text { BLEU }\end{array}$ & 1.016 & 6.178 & 3.850 & 4.486 & 2.622 & 35.650 & 170.800 & 0. \\
\hline \multirow{5}{*}{ 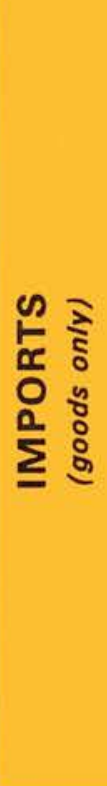 } & $\begin{array}{l}\text { total (CIF) } \\
\text { million US } \$\end{array}$ & 11,148 & 9,024 & $\begin{array}{c}\mathbf{2 9 , 6 9 7} \\
\text { BLEU }\end{array}$ & 32,293 & 9,856 & 6,818 & 52,819 & 68,975 & 4,385 & 518 & 3 \\
\hline & $\begin{array}{l}\text { from other OECD } \\
\text { countries } \\
\text { million US } \$\end{array}$ & 8,658 & 7,084 & $\begin{array}{c}24,094 \\
\text { BLEU }\end{array}$ & 27,460 & 8,038 & 4,131 & 35,662 & 49,126 & 3,056 & 435 & 3 \\
\hline & $\begin{array}{l}\text { from rest of world } \\
\text { million US } \$ \\
\text { (excl. unspecified) }\end{array}$ & 2,441 & 1,940 & $\begin{array}{c}5,588 \\
\text { BLEU }\end{array}$ & 4,833 & 1,818 & 2,156 & 17,139 & 19,783 & 1,328 & 83 & \\
\hline & $\begin{array}{l}\text { total imports } \\
\text { as percentage of GDP } \\
\text { at current prices }\end{array}$ & 14.2 & 27.3 & $\begin{array}{l}54.0 \\
\text { BLEU }\end{array}$ & 22.4 & 31.4 & 31.4 & 17.9 & 17.9 & 22.8 & 37.0 & 5 \\
\hline & $\begin{array}{l}\text { increase in volume of } \\
\text { total imports from } \\
1969 \text { to } 1974 \\
\text { percentage per year }\end{array}$ & 9.4 & 10.6 & $\begin{array}{l}9.2 \\
\text { BLEU }\end{array}$ & 7.4 & 4.5 & 8.6 & 8.9 & 7.8 & 8.4 & - $\bullet$ & \\
\hline \multirow{5}{*}{ 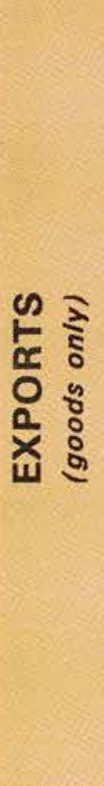 } & $\begin{array}{l}\text { total (FOB) } \\
\text { million US S }\end{array}$ & 11,071 & 7,163 & $\begin{array}{c}28,263 \\
\text { BLEU }\end{array}$ & 32,780 & 7,715 & 5,493 & 45,896 & 89,166 & 2,030 & 332 & 2 \\
\hline & $\begin{array}{l}\text { to other OECD } \\
\text { countries } \\
\text { million US } \$\end{array}$ & 7,178 & 5,023 & $\begin{array}{c}24,287 \\
\text { BLEU }\end{array}$ & 29,320 & 6,558 & 4,048 & 34,235 & 67,206 & 1,364 & 283 & 2, \\
\hline & $\begin{array}{l}\text { to rest of world } \\
\text { million US } \$ \\
\text { (excl. unspecified) }\end{array}$ & 3,825 & 2,140 & $\begin{array}{l}3,796 \\
\text { BLEU }\end{array}$ & 3,459 & 1,134 & 1,445 & 11,659 & 21,677 & 664 & 49 & 7 \\
\hline & $\begin{array}{l}\text { total exports } \\
\text { as percentage of GDP } \\
\text { at current prices }\end{array}$ & 14.1 & 21.7 & $\begin{array}{l}51.4 \\
\text { BLEU }\end{array}$ & 22.7 & 24.7 & 25.0 & 16.7 & 23.1 & 10.5 & 23.7 & 3 \\
\hline & $\begin{array}{l}\text { increase in volume } \\
\text { of total exports } \\
\text { from } 1969 \text { to } 1974 \\
\text { percentage per year }\end{array}$ & 5.1 & 10.9 & $\begin{array}{c}9.4 \\
\text { BLEU }\end{array}$ & 5.7 & 6.5 & 4.8 & 11.6 & 10.2 & 15.2 & - $\bullet$ & 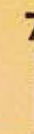 \\
\hline
\end{tabular}

\begin{tabular}{|c|c|c|c|c|c|c|c|c|c|c|c|c|}
\hline \multirow{4}{*}{ 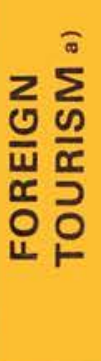 } & $\begin{array}{l}\text { receipts } \\
\text { millions of US } \mathrm{s}\end{array}$ & 260 & 2,289 & $\begin{array}{l}695 \\
\text { BLEU }\end{array}$ & 1,499 & 642 & 293 & 2,640 & 2,325 & 436 & 16 & 2 \\
\hline & $\begin{array}{c}\text { percentage change } \\
\text { over } 1973\end{array}$ & +26.8 & +4.5 & +10.8 & +15.0 & +11.1 & $+\mathbf{3 . 5}$ & +10.1 & +5.1 & -15.3 & +26.6 & + \\
\hline & $\begin{array}{l}\text { expenditures } \\
\text { millions of US } \mathrm{S}\end{array}$ & 491 & 890 & $\begin{array}{c}1,143 \\
\text { BLEU }\end{array}$ & 1,608 & 524 & 207 & 2,380 & 7,041 & 79 & 18 & \\
\hline & $\begin{array}{c}\text { percentage change } \\
\text { over } 1973\end{array}$ & +14.5 & +31.2 & +9.6 & +12.1 & $+\mathbf{5 . 0}$ & +6.2 & +10.1 & +7.9 & +9.0 & +37.9 & $+?$ \\
\hline
\end{tabular}




\begin{tabular}{|c|c|c|c|c|c|c|c|c|c|c|c|c|c|}
\hline$\frac{a}{2}$ & 至 & $\frac{2}{5}$ & 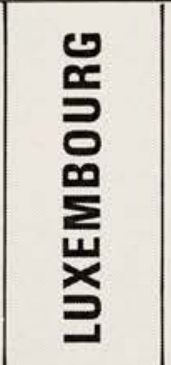 & 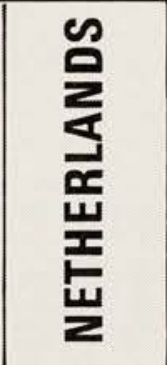 & 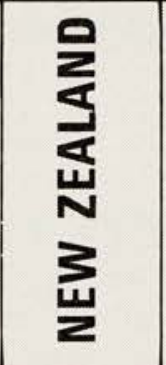 & 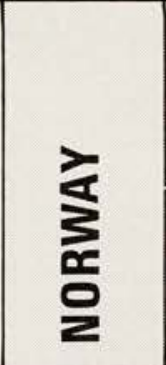 & $\begin{array}{l}\text { 둥 } \\
\text { 를 } \\
\text { 웅 }\end{array}$ & $\frac{\sum}{\frac{1}{\alpha}}$ & 름 & 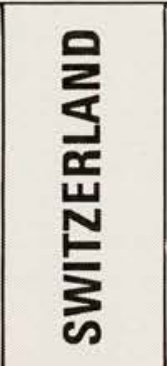 & 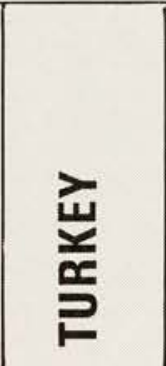 & 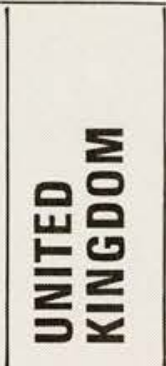 & 吕出 \\
\hline ound & Lira & Yen & $\begin{array}{c}\text { Luxem- } \\
\text { bourger } \\
\text { Franc }\end{array}$ & Guilder & $\begin{array}{c}\text { New } \\
\text { Zealand } \\
\text { Dollar }\end{array}$ & Krone & Escudo & Peseta & Krona & $\begin{array}{l}\text { Swiss } \\
\text { Franc }\end{array}$ & Lira & Pound & Dollar \\
\hline 494 & 683.550 & 305.150 & $\begin{array}{c}39.528 \\
\text { BLEU }\end{array}$ & 2.689 & 0.952 & 5.585 & 27.472 & 59.774 & 4.386 & 2.620 & 15.150 & 0.494 & 1.000 \\
\hline 814 & 40,972 & 62,110 & $\begin{array}{c}29,697 \\
\text { BLEU }\end{array}$ & 33,203 & - • & 8,438 & 4,444 & 15,436 & 15,748 & 14,445 & 3,729 & 54,231 & 100,972 \\
\hline 246 & 24,862 & 25,283 & $\begin{array}{c}24,094 \\
\text { BLEU }\end{array}$ & 25,008 & - & 7,179 & 3,192 & 9,596 & 12,991 & 12,643 & 2,633 & 36,385 & 59,657 \\
\hline & 16,099 & 36,815 & $\begin{array}{c}\mathbf{5 , 5 8 8} \\
\text { BLEU }\end{array}$ & 8,194 & ・ & 1,258 & 1,213 & 5,838 & 2,758 & 1,801 & 1,096 & 17,790 & 41,300 \\
\hline 6.6 & 27.3 & 13.8 & $\begin{array}{l}54.0 \\
\text { BLEU }\end{array}$ & 48.0 & • • & 36.2 & - • & 21.0 & 28.2 & 32.2 & 12.8 & 28.4 & 7.3 \\
\hline 3 & 6.1 & 11.0 & $\begin{array}{r}9.2 \\
\text { BLEU }\end{array}$ & 7.1 & 12.6 & 6.9 & - & 5.3 & 5.1 & 6.3 & - & 6.9 & 5.6 \\
\hline 632 & 30,293 & 55,536 & $\begin{array}{c}28,263 \\
\text { BLEU }\end{array}$ & 32,432 & - $\cdot$ & 6,292 & 2,254 & 7,087 & 15,823 & 11,934 & 1,536 & 38,703 & 98,506 \\
\hline 410 & 21,365 & 25,636 & $\begin{array}{c}24,287 \\
\text { BLEU }\end{array}$ & 27,639 & - & 5,162 & 1,780 & 5,139 & 13,020 & 8,905 & 1,084 & 27,435 & 61,573 \\
\hline 98 & 8,444 & 29,899 & $\begin{array}{l}3,796 \\
\text { BLEU }\end{array}$ & 4,138 & - & 1,130 & 438 & 1,926 & 2,803 & 3,028 & 452 & 11,127 & 36,382 \\
\hline 9.1 & 20.3 & 12.3 & $\begin{array}{l}51.4 \\
\text { BLEU }\end{array}$ & 46.9 & - & 27.0 & - $\cdot$ & 9.6 & 28.3 & 26.6 & 5.2 & 20.3 & 7.1 \\
\hline .1 & 7.2 & 12.6 & $\begin{array}{c}9.4 \\
\text { BLEU }\end{array}$ & 10.6 & -1.4 & 5.7 & - & 10.2 & 7.6 & 6.1 & - & 6.4 & 9.4 \\
\hline 54 & 1,915 & 234 & $\begin{array}{l}695 \\
\text { BLEU }\end{array}$ & 1,033 & 133 & 298 & 443 & 3,188 & 275 & 1,415 & 194 & 1,957 & 4,032 \\
\hline 14.1 & -19.3 & +12.0 & +10.8 & +7.6 & +34.7 & +18.0 & -13.8 & +3.1 & +25.6 & +2.7 & +12.9 & +10.7 & +18.6 \\
\hline 70 & 1,228 & 1,358 & $\begin{array}{c}1,143 \\
\text { BLEu }\end{array}$ & 1,346 & 253 & 387 & 255 & 326 & 769 & 665 & 152 & 1,601 & 5,973 \\
\hline & -12.4 & +8.5 & +9.6 & +14.7 & +39.1 & +31.5 & +9.9 & +20.4 & +7.1 & +13.9 & +63.4 & -4.9 & +8.1 \\
\hline
\end{tabular}




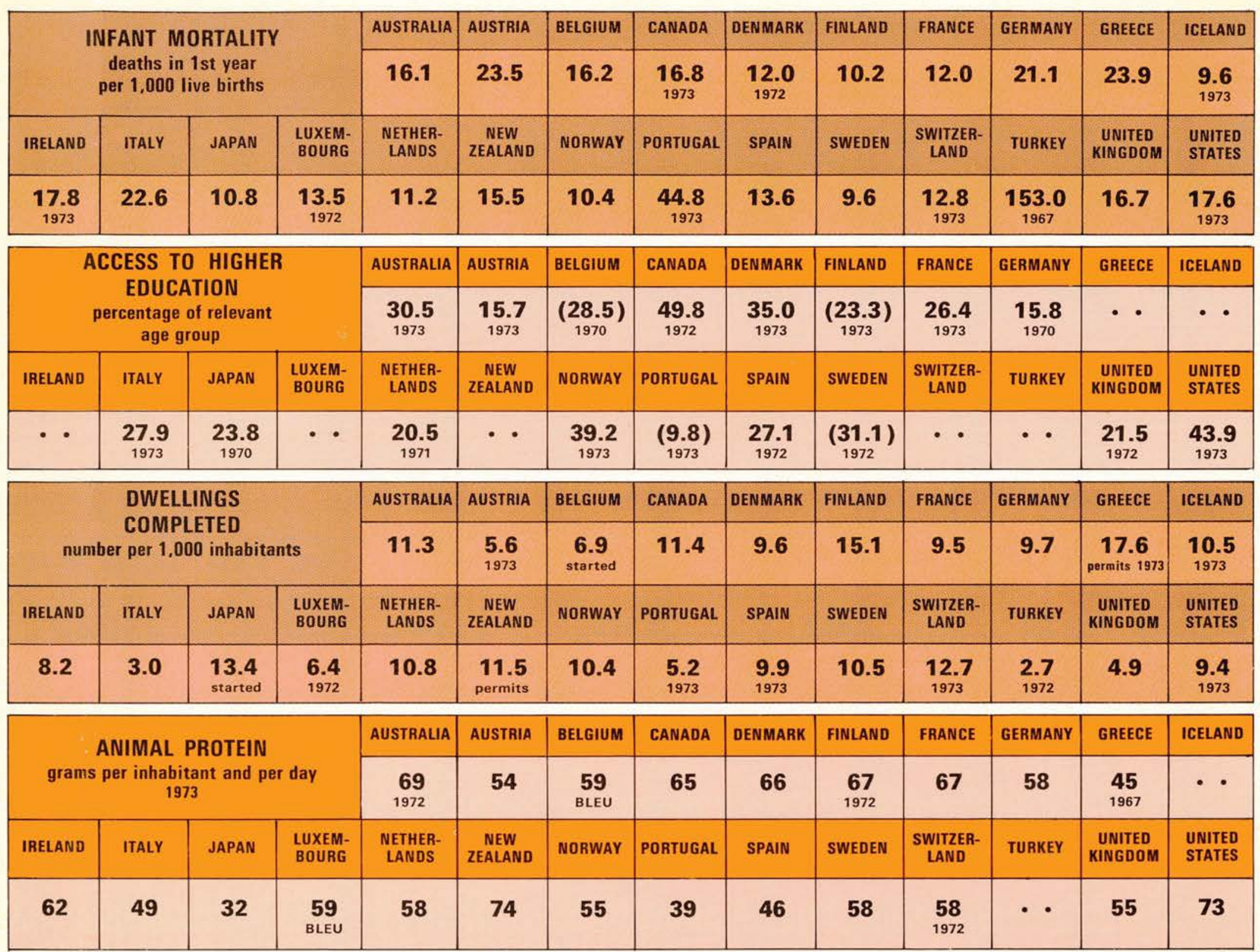

\begin{tabular}{|c|c|c|c|c|c|c|c|c|c|c|c|c|c|}
\hline \multirow{2}{*}{\multicolumn{4}{|c|}{$\begin{array}{l}\text { Per Capita } \\
\text { ENERGY CONSUMPTION } \\
\text { total primary energy requirements } \\
\text { in tons of oil equivalent (1) }\end{array}$}} & \multirow{2}{*}{$\begin{array}{c}\text { AUSTRALIA } \\
4.39 \\
\end{array}$} & \multirow{2}{*}{$\frac{\text { AUSTRIA }}{3.05}$} & \multirow{2}{*}{$\begin{array}{r}\text { BELGiUM } \\
4.65\end{array}$} & \multirow{2}{*}{$\begin{array}{r}\text { CANADA } \\
8.56\end{array}$} & \multirow{2}{*}{$\begin{array}{r}\text { DENMARK } \\
3.53\end{array}$} & \multirow{2}{*}{\begin{tabular}{|r|} 
FINLAND \\
4.70
\end{tabular}} & \multirow{2}{*}{$\begin{array}{l}\text { FRANCE } \\
\mathbf{3 . 3 9}\end{array}$} & \multirow{2}{*}{\begin{tabular}{|c|} 
GERMANY \\
4.25
\end{tabular}} & \multirow{2}{*}{\begin{tabular}{|c|} 
GREECE \\
1.42 \\
\end{tabular}} & \multirow{2}{*}{\begin{tabular}{|l|} 
ICELAND \\
$\mathbf{5 . 3 5}$
\end{tabular}} \\
\hline & & & & & & & & & & & & & \\
\hline IRELAND & ITALY & JAPAN & $\begin{array}{l}\text { LUXEM- } \\
\text { BOURG }\end{array}$ & $\begin{array}{l}\text { NETHER- } \\
\text { LANDS }\end{array}$ & $\begin{array}{c}\text { NEW } \\
\text { ZEALAND }\end{array}$ & NORWAY & PORTUGAL & SPAIN & SWEDEN & $\begin{array}{l}\text { SWITZER- } \\
\text { LAND }\end{array}$ & TURKEY & $\begin{array}{c}\text { UNITED } \\
\text { KINGDOM }\end{array}$ & $\begin{array}{l}\text { UNITED } \\
\text { STATES }\end{array}$ \\
\hline 2.40 & 2.47 & 3.05 & 13.92 & 4.55 & 3.20 & 4.91 & 0.90 & 1.72 & 5.45 & 3.43 & 0.45 & 3.82 & 8.09 \\
\hline
\end{tabular}

(1) These figures are not comparable with those of 1973 because hydro-and nuclear electricity have been treated in a different way.

\begin{tabular}{|c|c|c|c|c|c|c|c|c|c|c|c|c|c|}
\hline \multirow{2}{*}{\multicolumn{4}{|c|}{$\begin{array}{c}\text { TELEPHONES } \\
\text { number per } \\
1,000 \text { inhabitants } \\
1973\end{array}$}} & AUSTRALIA & AUSTRIA & BELGIUM & CANADA & DENMARK & FINLAND & FRANCE & GERMANY & GREECE & ICELAND \\
\hline & & & & 355 & 246 & 257 & 528 & 400 & 329 & 217 & 287 & 187 & 381 \\
\hline IRELAND & ITALY & JAPAN & $\begin{array}{l}\text { LUXEM- } \\
\text { BOURG }\end{array}$ & $\begin{array}{l}\text { NETHER- } \\
\text { LANDS }\end{array}$ & $\begin{array}{c}\text { NEW } \\
\text { ZEALAND }\end{array}$ & NORWAY & PORTUGAL & SPAIN & SWEDEN & $\begin{array}{l}\text { SWITZER- } \\
\text { LAND }\end{array}$ & TURKEY & $\begin{array}{c}\text { UNITED } \\
\text { KINGDOM }\end{array}$ & $\begin{array}{l}\text { UNITED } \\
\text { STATES }\end{array}$ \\
\hline 120 & 229 & 357 & 382 & 320 & 475 & 329 & 109 & 181 & 594 & 560 & 21 & 340 & 657 \\
\hline \multirow{2}{*}{\multicolumn{4}{|c|}{$\begin{array}{c}\text { TELEVISION SETS } \\
\text { number per } \\
1,000 \text { inhabitants } \\
1973\end{array}$}} & AUSTRALIA & AUSTRIA & BELGIUM & CANADA & DENMARK & FINLAND & FRANCE & GERMANY & GREECE & ICELAND \\
\hline & & & & $\begin{array}{l}227 \\
1972\end{array}$ & 237 & 244 & 348 & $\begin{array}{l}282 \\
1972\end{array}$ & 263 & $\begin{array}{l}237 \\
1972\end{array}$ & 298 & $\begin{array}{l}58 \\
1972\end{array}$ & $\begin{array}{l}220 \\
1972\end{array}$ \\
\hline IRELAND & ITALY & JAPAN & $\begin{array}{l}\text { LUXEM- } \\
\text { BOURG }\end{array}$ & $\begin{array}{l}\text { NETHER- } \\
\text { LANDS }\end{array}$ & $\begin{array}{c}\text { NEW } \\
\text { ZEALAND }\end{array}$ & NORWAY & PORTUGAL. & SPAIN & SWEDEN & $\begin{array}{l}\text { SWITZER- } \\
\text { LAND }\end{array}$ & TURKEY & $\begin{array}{c}\text { UNITED } \\
\text { KINGDOM }\end{array}$ & $\begin{array}{l}\text { UNITED } \\
\text { STATES }\end{array}$ \\
\hline 176 & 208 & 229 & $\begin{array}{r}220 \\
1971 \\
\end{array}$ & 258 & 304 & 249 & 66 & 164 & 339 & 253 & 7 & 309 & 523 \\
\hline
\end{tabular}




\title{
Reducing OECD Countries' Dependence on Imported Oil
}

\author{
by Dr. Ulf Lantzke (1), Executive Director of International Energy Agency \\ and Special Counsellor to Secretary General of the OECD on Energy Questions.
}

(2)

$\mathbf{S}$ ince the end of 1973, governments have begun to introduce measures to limit the growth of energy consumption and to diversify sources of supply. Even without government encouragement, the OPEC price increases would have led-and are in fact leading - to some alterations in the pattern of energy supply and demand predicted prior to 1974 . Indeed some studies made soon after the largest of those increases predicted very large changes. Now, after two years' time to reflect more carefully, we believe these studies to have been too optimistic.

One large change that is still expected is a reduction in economic growth over the next 10 years. This change is only partly related to the increase in international oil prices, but it is expected to contribute to reducing growth in energy consumption substantially more than was previously anticipated (although there may be some offsetting effect due to increased energy requirements resulting from the adoption of certain forms of environmental controls). Any reduction in oil import dependence achieved by this route, however, is a somewhat mixed blessing.

Another consequence of the oil price rise is the realisation of significant economies in the use of energy. In 1974, OECD energy consumption fell 2.1 per cent below the 1973 level despite a drop in GDP of only 0.4 per cent. While a portion of this fall is attributable to the temporary disruption in oil imports during the first part of 1974, and to psychological reactions which may have diminished since then, another part is undoubtedly due to the price increases. And the price-induced effect is expected to become larger over time as consumers gradually undertake the investments needed to reduce their consumption on a longer-term basis. In 1975, with a real GDP drop of 2 per cent, energy consumption fell by 3.3 per cent. It now appears that the contribution of energy consumption to reducing dependence on oil imports will be greater than the contribution made by increasing energy production in the industrialised countries. And energy savings have some important advantages when compared with increased energy production. They help to conserve the world's energy resources; they have beneficial environmental effects, and they may be realised more quickly than production increases.

\section{Energy Supply}

Over the very long-term there is a large potential for increasing energy supplies in the industrialised countries, but these increases cannot be realised overnight: lead times are long, and for each form of energy there are certain obstacles to overcome. These considerations can be illustrated by looking at the various energy sources individually.

\section{- Oil and Natural Gas}

For the past seven years, oil and gas production in the traditional producing areas of the United States and Canada has exceeded new discoveries, and the pressure decline which occurs as existing reserves are depleted has resulted in diminishing production. Large discoveries have been made in frontier areas such as Alaska and the Canadian Arctic, but very large and costly investments in transportation are needed to bring the products to market, and the necessary facilities take a long time to build.

Nor is the construction phase the only time-consuming one; there is also a necessarily prolonged period before approval to begin construction is granted during which time it has to be shown that the environmental effects are tolerable, that adequate compensation is paid to the local groups affected, that the projects will not have intolerably adverse macro-economic effects, and that the benefits to the societies affected generally exceed the costs. Furthermore, since transportation costs are so large, the oil or gas reserves needed to justify building such projects must be correspondingly large. Because of these considerations, the natural gas discovered in the Canadian Arctic Islands at the start of the 1970's is not expected to reach markets until the mid to late 1980's.

Further reserves are expected to be found onshore and offshore in North America, close to markets, but until they are found we do not know how much is there. Projections of production for even as short a period as the next 10 years include supplies from reserves which have not yet been proved up. Naturally there is considerable uncertainty surrounding these.

The large amounts of oil and gas found in the North Sea will help a great deal to reduce European oil imports, and to keep them from exceeding current levels for 10 years or more. From 1976 on, production increases from the North Sea will more than offset decreases in the United States which will continue to occur until Alaskan oil reaches the market. However, expansion of oil production has fallen behind schedule due to understandable difficulties encountered in trying to construct facilities in the North Sea.

Government policies towards oil and gas have evolved rapidly in the past two years making it difficult to sort out all their consequences. Tax systems have been modified in order to bring about an appropriate distribution of the windfall profits on production in OECD countries which have resulted from the general increase in oil prices. While these changes were underway, investors were left uncertain as to the profitability of future production, but this uncertainty is decreasing.

In some countries controls on prices of oil and gas have been adopted for anti-inflationary and other reasons. Some of these

(1) From a speech presented at the annual conference of the Japan Industrial Forum, Inc. Tokyo. (2) OECD's activities in the field of energy are carried out through its Committee on Energy Policy and by the International Energy Agency. 
have existed for a long time, but others were introduced after 1973. The rate at and the extent to which they are removed will affect production.

In some cases, rights to explore in certain regions have been granted more slowly than hoped, partly for environmental reasons, partly out of concern for the economic and social dislocation which would accompany rapid development.

Governments which export oil or gas are subject to pressures with respect to the extent to which exports should be allowed; there is concern in some quarters that unrestricted exports would lead to later difficulties in covering future domestic requirements.

Costs of production from Canadian tar-sands have escalated more rapidly than the general price level in the past year, thereby diminishing prospects for rapid development. In early 1975, it was necessary for the Canadian government, together with two provincial governments, to provide financial support for the second tar-sands plant in order to ensure that its construction will continue on schedule. Tar-sands production is expected to be about 15 million tons annually by 1985 .

Taking account of these considerations, and assuming no significant new policy departures, it is estimated that the increase in OECD oil production between 1974 and 1985 could be about 330 million tons compared with total additional energy requirements of 1,700 million tons oil equivalent. Additional gas production could be about 60 Mtoe, with increases in European, Canadian and Australian gas production being partly offset by decreases in the United States.

An important means of diversifying sources of supply is to increase imports of natural gas. The increase in gas imports to 1985 could be about 125 Mtoe, part coming from the USSR and part from OPEC countries. An unresolved question concerns the extent to which imports of gas from OPEC countries are a more reliable source of supply than oil. Gas, however, has an advantage over oil in that it causes less pollution.

\section{- Coal}

OECD coal production could increase by 310 Mtoe between 1974 and 1985 , with nearly all of the expansion likely to take place in the United States, Canada and Australia. Prior to 1974 European coal production was expected to decline because of high costs. It is now anticipated that present levels will be maintained or increase a little. Costs outside of Europe are lower than oil prices in terms of equivalent energy content, but there are other obstacles to a greater expansion including limited demand. Since there is no longer much demand for coal for the residential, commercial or transportation sectors, nor for steam coal in industry, the available coal will be consumed mainly in electricity generation and for coking purposes in the steel industry. Slower economic growth in the future, however, could reduce the growth of steel and electricity output and thereby limit the demand for coal. To some extent coal can be used in electric generation to displace oil and perhaps also as a substitute for new nuclear plants, but difficulties of controlling pollution from coal burning plants limit this possibility in some regions, and in most areas coal-produced electricity is more costly than nuclear.

One way to get around the demand constraint associated with coal is to transform it into liquid or gaseous form, but at present the costs of doing so are still too high to expect any substantial progress in this direction before 1985 .

Environmental difficulties relating to the production of coal may also impose some constraint. Further uncertainties arise out of possible construction delays and transportation bottlenecks.

\section{- Hydro and Geothermal}

Hydro and geothermal energy could contribute an additional 95 Mtoe to OECD production by 1985 . Further increases in hydro power are limited by lack of available sites while lead times needed to increase geothermal production are long because there are still some technical and environmental problems to be solved.

\section{- Nuclear Power}

As to the much-publicised option of nuclear power, one of the most important reasons for the widespread interest in it is that nuclear power is almost the only promising means available to many of the relatively energy-poor countries for diversifying energy supplies. The lack of a domestic market large enough to justify a nuclear plant may preclude use of this option by some countries, but even a country as small as Luxembourg is planning to build a nuclear power station.

By 1980 the OECD could have 180 gigawatts of nuclear capacity, and by 1985, 375 gigawatts, and nuclear energy's contribution to the increase in OECD energy production between 1974 and 1985 could be 415 Mtoe, which is substantially greater than the contribution of any other single form of energy. Given the technical complexity and the very large capital investment associated with nuclear power, increases of these magnitudes would constitute a major accomplishment. Nevertheless these estimates are considerably less than the targets adopted by governments after the OPEC oil price increase; indeed they are lower than predictions made before 1974 . Furthermore, in order to achieve the 1985 targets the current lead times of 10 years imply that it will be necessary to establish the required sites by the end of 1976, and it is not certain that this can be done.

One of the most important reasons for reducing nuclear forecasts has nothing whatever to do with difficulties of building nuclear plants. It is that the need for nuclear power will be less because of the expectation that the growth in energy consumption of the industrialised countries will be reduced, and therefore also the growth in their electricity consumption.

Other factors include financing difficulties, licensing, construction and commissioning problems. For example, the accumulation of the larger volume of capital required to finance new nuclear power growth-already estimated a year ago at over $\$ 250$ billion for the OECD area-poses problems at a time when ambitious investment policies in the energy sector are being hampered by government restrictions on aggregate demand intended to control inflation and redress balances of payments. Moreover, costs of nuclear power stations are more sensitive to inflation and interest rates than the less capital-intensive fossil-fuel-burning plants. Although the earlier bottlenecks which were experienced in some countries on licensing, construction and commissioning of nuclear installations have now largely disappeared, due to more streamlined regulatory procedures within national administrations and improved engineering experience, a new form of regulatory obstacle is rapidly becoming consolidated-public opposition to the widespread growth of civilian nuclear installations on the grounds of health and safety.

So far nuclear fuel has been plentiful in supply and low in cost. However, there may soon be problems. Due to tripling of the price of natural uranium over the last three years and the 
prospect of steep rises in the cost of enrichment facilitieshitherto subsidised by national governments - nuclear fuel costs may in future not be a negligible component of cost as they have in the past. Furthermore, present resources of low-cost uranium correspond to only about 13 years of forward requirements, and there are not yet enough enrichment facilities under contract to provide adequate full supplies over the lifetime of nuclear plants now being planned.

Because of the steep increase in both capital costs and fuel costs, it is not certain that nuclear power will continue to be cheaper than electricity generated by fossil fuels.

While these problems are serious and will require close attention, it seems certain that nuclear power will make a major contribution towards increasing energy supplies in the next ten years, and that by the end of that period it will represent a significant proportion of total energy production in the industrialised countries.

\section{- Other Sources of Energy}

Other sources of energy, such as solar, wind power, wave power, biomass conversion, methanol and thermonuclear fusion have promising prospects and much research is being carried out to overcome technological problems. However with the possible exception of solar energy, they will not make a significant contribution over the next decade.

\section{Government Policies}

Putting together these various projections but mindful of the uncertainty surrounding them, we find that, by 1985, OECD's oil import dependence could be reduced from the ratio of 45 per cent expected prior to 1974 to a level well below the present ratio of 36 per cent. This is a significant improvement, but it nevertheless entails a large absolute increase in oil imports above 1974 levels and hence could promote a pronounced sellers' market. Furthermore, since most of the production increases are expected to occur in a few, relatively energy-rich, countries, the majority of the industrialised nations will continue to be dependent on imports for all, or nearly all, of their oil requirements.

A key assumption underlying these projections is that government policies will continue unchanged. There are now some indications that the application of new, more vigorous, policies could have greatly beneficial consequences. The policy approach that could be taken may be divided into two categories. The first includes measures to reduce import dependence by increasing indigenous supplies of energy and reducing growth in consumption of energy.

In the second category are policies related to the consideration that the availability of energy is not evenly distributed among consuming countries. One of the most important options, perhaps the most important, is to allow domestic energy prices to rise to international levels. This will allow market forces to have a fuller role, and will serve to encourage both energy savings and increases in energy production, both of which lead to less dependence on a limited number of outside sources of energy supply.

Higher prices alone are not sufficient to achieve the desired amounts of energy savings. Other measures to encourage conservation include minimum requirements for insulation in residential and commercial buildings, taxes and other measures to discourage the use of large or powerful automobiles which consume large amounts of gasoline, lower speed limits on highways, rationalisation of airplane flight schedules, encouragement of public transportation relative to automobiles, laws requiring appliance sellers to indicate to potential buyers the amounts of energy required to operate their products, publicity campaigns, special economy efforts within government organisations, and so on.

As to production, if the environmental and social problems which have made some governments reluctant to permit fullscale exploration in certain oil and gas bearing areas could be resolved in such a way as to permit more rapid granting of rights to explore, it is possible that a great deal more production could be achieved.

\section{PROJECTED INCREASES IN OECD ENERGY REQUIREMENTS 1974-1985... AND HOW THEY WILL BE MET (Assuming no change in policies)}

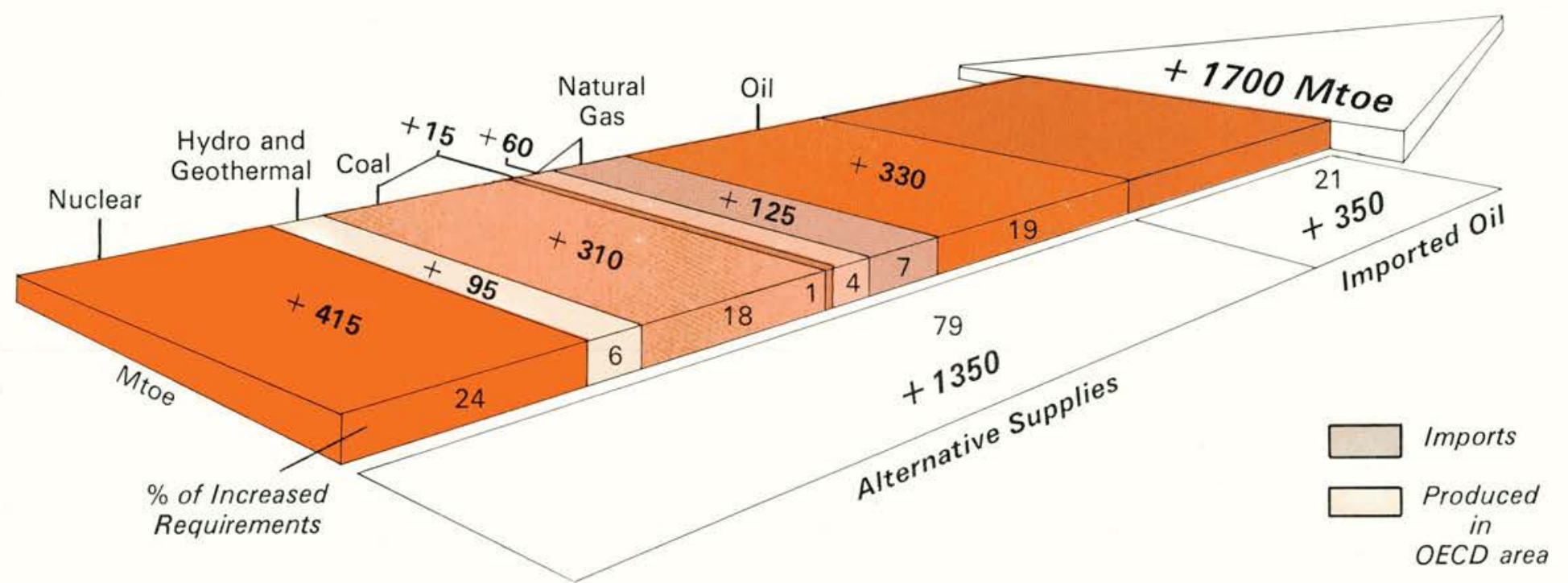



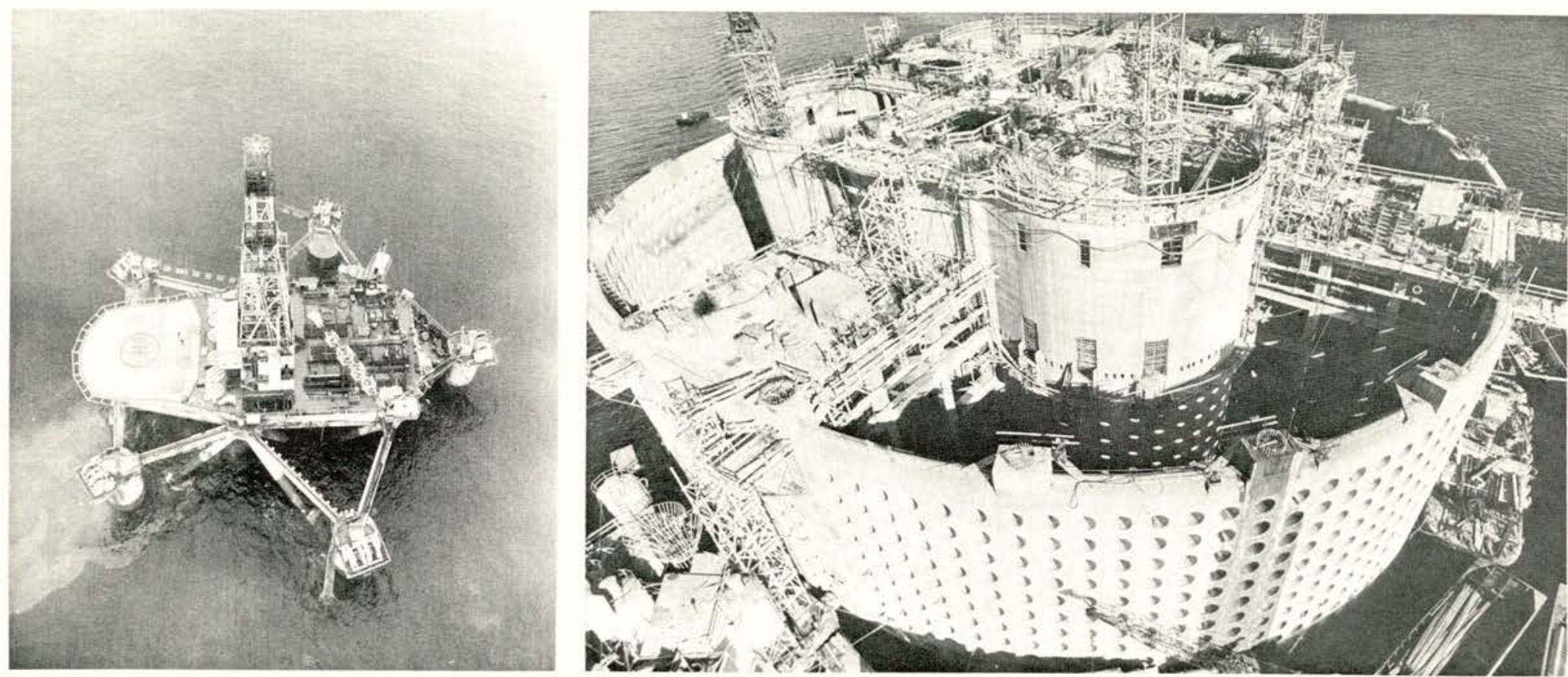

Drilling for oil (left) and an oil reservoir with a 215,000 ton capacity (right) in the North Sea.

Since a slowdown in the rate of growth of electricity consumption is expected to act as a constraint on the production of both coal and nuclear power, it is useful to investigate whether ways can be found to increase electricity's share in total energy consumption. This option needs to be appraised very carefully because some seemingly promising uses for electricity result in excessively large wastage of potential useful energy. One possibility, however, may be to increase the use of electricity in the transportation sector, for example in railways and urban travel, particularly in North America, where electricity is not generally used for these functions. Efforts to ensure that projects are not delayed because of financial difficulties may in the case of nuclear power mean ensuring that increases in electricity tariffs do not lag behind cost increases as often happens in periods of inflation.

In addition, prior studies may anticipate bottlenecks arising out of shortages of construction and other materials so that measures can be taken to alleviate difficulties.

As to environmental difficulties surrounding new energy projects, careful studies of possible environmental consequences would be in order so as to establish as accurately as possible the extent of conceivable damages now too often not well enough understood.

It is important that the environmental effects of the production and use of an individual form of energy not be considered in isolation; it is evident that restrictions on one form of energy will necessitate making more use of other forms, thereby intensifying the environmental difficulties associated with those. Indeed, environmental policies as a whole need to be carefully coordinated with overall energy policies.

Regarding nuclear power special attention needs to be directed towards solving certain key technical problems, for example those relating to radioactive waste disposal and commercial fastbreeders.

These are only a few of the approaches which governments might adopt to reduce their energy import dependence. If, however, measures along these lines are vigorously pursued, oil imports by the industrialised countries might be reduced by as much as 8 million barrels a day below levels projected on the assumption that present policies will continue; and overall oil import dependence could be reduced to 24 per cent. Cooperation among consuming countries can help to achieve these gains.

According to the economists' theory of exhaustible resources, the optimal solution to the problem of choice of alternative energy is to use the lowest-cost resources first, then the next lowest-cost forms, and so on, with the highest-cost sources being left until last. If costly resources are resorted to before the cheap supplies are used up, society must direct into energy production resources which could be invested elsewhere sooner than otherwise would be the case, thereby sacrificing the real returns that could be achieved in the interim. To ensure that consumers actually use resources in the appropriate sequence, the theory requires that prices correspond to real costs of production. It also requires that there be free trade in energy to permit all nations to have access to the lowest-cost energy before having to shift to more costly sources.

Unfortunately, the real world is not like this. Prices have been set above costs. Nations place restrictions on energy exports and imports, thereby forcing the resort to higher cost energy sooner than otherwise and requiring diversion of productive resources from elsewhere. Furthermore, the danger that trade interference can be used for political purposes obliges countries to limit their dependence on imports.

And so we must try to do the best we can within the existing situation, taking account of all the constraints. The approach so far is to search for ways of protecting ourselves from dangers relating to potential interference with trade, for example, to economise on the use of energy, to increase indigenous supplies and to emphasise trade with countries that give the greatest assurance of a continuing flow of supplies.

However, it is equally important to continue, and indeed to increase, efforts taken at the same time along a different route, namely of trying to find ways to achieve a better relationship between prices and costs, and ways to bring about greater trust between trading partners, thereby encouraging freer and more secure international movements in energy. 


\section{Anti-Recession Policies in Sweden}

In its most recent examination of Sweden (1) OECD concludes that the "Swedish experience of 1974 and 1975 provides an example of what can be achieved by a combination of flexible demand management and selective policies - sometimes referred to as 'fine-tuning'-during serious international recessions even in a country heavily dependent on foreign trade". While priorities, institutions and attitudes differ, the report notes that aspects of Swedish policy-making should be of interest to other countries.

This article presents the conclusions of the 1975-76 Annual Review of Sweden by OECD's Economic and Development Review Committee.

$\mathrm{D}$ uring the last two years, faced with strong deflationary influences from the international recession, the emphasis of Swedish economic policy has been on maintaining full employment, and in this it has succeeded remarkably well. Not only has unemployment remained very low to date, but domestic demand and activity have been maintained in ways which have added considerable strength to the economy: industrial fixed investment increased in 1974 and 1975 at an average annual rate of $7-8$ per cent in real terms, a marked contrast to the declines experienced generally elsewhere; and during the same period, inventory investment contributed more than 3 per cent to the growth of GDP, part of it in stocks of exportable goods ready to be shipped when foreign demand recovers. (See inset)

The good performance in terms of the size, timing and nature of the measures taken has been facilitated by flexible procedures and by the high degree of preparedness of counter-cyclical policy

(1) OECD Economic Surveys - Sweden, April 1976.

\section{The Stockbuilding Scheme}

The Swedish authorities took measures to stimulate stockbuilding so as to avoid a weakening of aggregate demand due to inventory adjustments. Thus, a scheme was introduced for one year with effect from lst July, 1975 (1), entitling firms to a compensation equivalent to 20 per cent of the rise in stocks, the proviso being that employment was not to be reduced during the period concerned. The main characteristics of the scheme are the following :

- the starting period for the calculation of compensation is flexible to allow for differences in the relative cyclical position between sectors and industries

- the stock increase is calculated in volume terms rather than in current prices and only increases over and above a "normal" (determined as the average stock level for the previous three years) stock level entitle firms to compensation

- the employment requirements are strict as no reduction in the labour force is allowed and even a shortening of the work week is considered a disqualifying circumstance

- to ensure that liquidity problems will not be a constraint on stockbuilding, firms can receive 75 per cent of the estimated compensation in advance, and borrowing for the purpose of inventory formation is covered by a government guarantee.

A roughly similar stockbuilding scheme was used in 1972.

\section{Investment Funds}

\section{...Ordinary}

According to Swedish tax legislation, firms are allowed to set aside a certain share of profits for future investment. These reserves, which are deductible from taxable income, are deposited in the Central Bank and their release-normally during unfavourable cyclical conditionsis subject to approval by the authorities.

\section{...and Special}

Two special compulsory deposit schemes, one of which was intended to improve job environment, were introduced in 1974 to supplement the ordinary investment funds; they effectively "froze" 35 per cent of net taxable profits on closed bank accounts.

By the end of June 1975 ordinary and compulsory funds totalled Kr. 6 billion.

Early in 1975 the authorities decided that enterprises undertaking building investments should be allowed to draw on the ordinary investment funds throughout the year and on the special investment funds for the second half of the year. The release of funds was subsequently extended to all types of investment-including inventory formation - and by the end of the year applications, corresponding to 70 per cent of total funds available, had been approved.

(1) Sawmills have been entitled to the stock scheme since the beginning of 1975 . It has been extended to the end of 1976 . 
arrangements. The investment funds (see inset) seem again to have demonstrated their efficacy as an instrument of influencing the timing - and, possibly, the level-of business fixed investment. The inventory scheme and the employment condition attached to it, have had important demand and employment effects. A well-known feature of Swedish policy-making is the various labour market schemes which offer training, re-training or alternative temporary work to those who, despite active general demand management, lose their jobs. (Table 1)

It is also interesting that, despite the size of the measures taken, the public sector deficit in Sweden has been smaller than in many other countries, reflecting notably the fact that the budgetary costs of some important counter-cyclical measures have been small, and that the budget has not been adversely affected by heavy payments of unemployment benefits and a falling tax base. Moreover, the financing of the budget deficit has been undertaken in ways which have enabled an increased supply of short and long-term funds to the enterprise sector to go handin-hand with only a moderate increase in the money supply.

\section{The Strategy for 1976}

For 1976 the strategy of the Swedish authorities is largely to rely on the measures already taken, and to wait for a recovery of exports to take over as the primary expansionary factor. In present circumstances, a "wait and see" attitude would indeed seem appropriate, for several reasons. During the first half of the year the measures already adopted-notably the release of investment funds and the inventory scheme - will help to maintain demand and employment. World trade is already recovering and should progressively affect Swedish exports. While the strength of the upturn in world trade is uncertain, the adoption of additional stimulative measures would entail the risk of an excessive increase in aggregate demand in 6-12 months time. Moreover, even if demand should rise less than expected at present, the labour market schemes provide an important buffer.

The balance of payments and price situation also point to the need for cautious demand management. The current external deficit that has arisen is rather smaller than would be expected from the point of view of Sweden's cyclical position-mainly because of the favourable development of the terms of tradeand its financing has not created problems. Nevertheless, the cumulative size of the deficit is growing, and it is an important aim of government policy to restore equilibrium of the current external balance by 1980 .

Despite the importance attached to reducing the rate of inflation, Sweden has been less successful in this respect than in maintaining full employment. The price rise has not been higher than the OECD average, but there has been no deceleration over the last 18 months in line with the slowdown or fall in world trade prices. The rise in domestic labour costs accelerated strongly in 1975 (see chart) and 1976 may also see a faster increase in wage costs in Sweden than in most other Member countries. The uneven profit developments in Swedish industry over the last couple of years, with marked increases in profits in certain raw materials and semi-manufacturing industries, may have led to wage increases which create difficulties in other branches. There is little the authorities can do in the immediate future as 1976 is not a bargaining year, but it will be important to achieve a relative improvement of the labour cost position of Swedish industry during the national wage round in 1977. Economic policy could play an important role in this respect. In the first place, it would seem important to develop a consensus amongst

\section{A. Total Hourly Wage Costs (Manufacturing) in Selected OECD Countries}

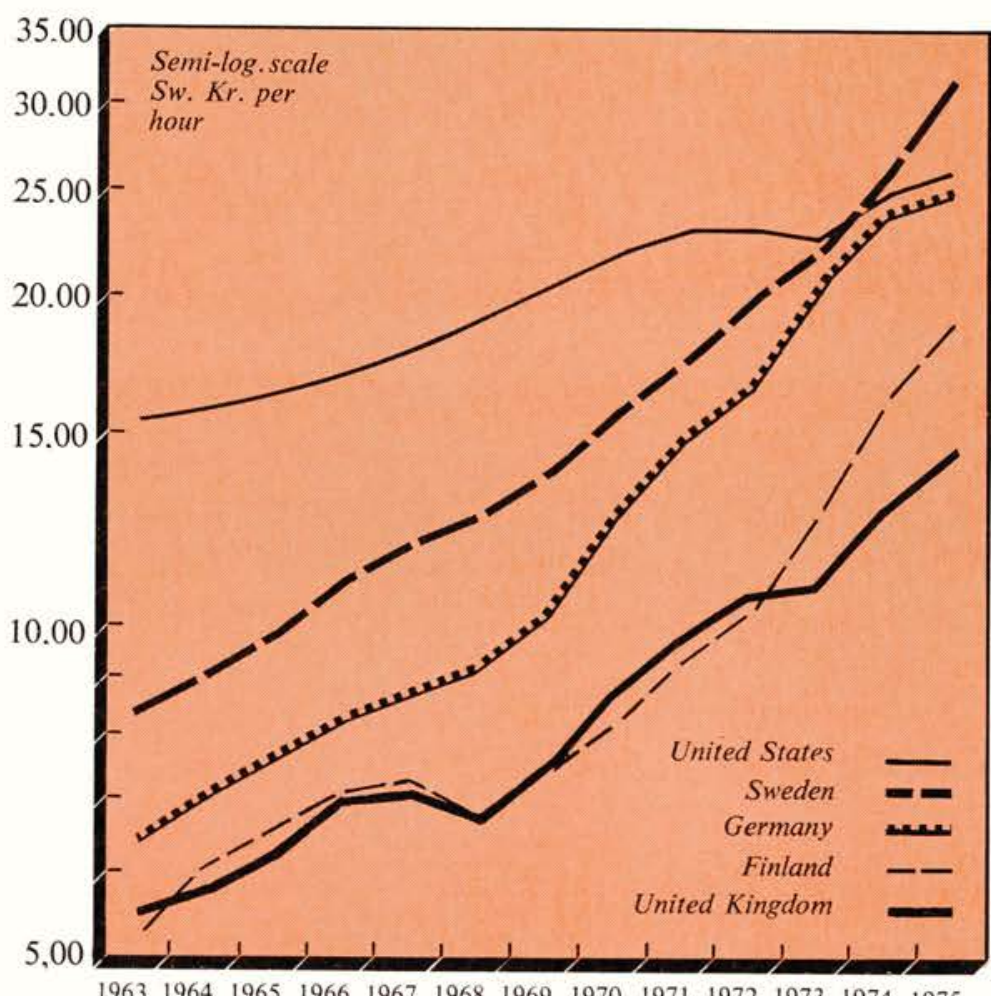

$\begin{array}{lllllllllllll}1963 & 1964 & 1965 & 1966 & 1967 & 1968 & 1969 & 1970 & 1971 & 1972 & 1973 & 1974 & 1975\end{array}$

Sources : Swedish Employers' Confederation and OECD Secretariat.

\section{Labour Market Indicators (Thousands of persons)}

During the period 1972-1975 Sweden managed to increase employment despite a growth in the labour force brought about by increased immigration, higher participation rates for women and the changing age of the population.

\begin{tabular}{l|r|r|r|r}
\hline & 1972 & 1973 & 1974 & 1975 \\
\hline Unemployed & 107 & 98 & 80 & 67 \\
Potential job seekers (1) & 97 & 90 & 83 & 78 \\
Labour market measures & 100 & 110 & 99 & 92 \\
$\quad$ Job training & 43 & 46 & 41 & 36 \\
Public relief work & 32 & 33 & 23 & 17 \\
Archive work & 10 & 13 & 14 & 15 \\
Sheltered and semi- & 15 & 18 & 21 & 24 \\
sheltered work & 3,970 & 3,977 & 4,043 & 4,129 \\
\hline Labour force & & & &
\end{tabular}

(1) According to labour force sample surveys potential job seekers are those persons who are not counted as unemployed but who indicate that they would have been looking for gainful employment if there had been a real chance of finding $a$ job.

Source : Swedish Labour Market Statistics.

those concerned on the real scope for higher wages in 1977, given the current balance of payments deficit, the cost position of Swedish industry, and the desirability of maintaining a high rate of business fixed investment. Secondly, assuming that a concensus can be developed, fiscal policy can help to achieve a given increase in real disposable wage incomes with as small a nominal pay increase as possible. A degree of success in these respects similar to that recently attained in demand management would considerably improve the outlook both for prices and the economy in general. 


\section{Low-Cost Improvement of the Urban Environment}

The economic climate of the Seventies coupled with increasing public opposition to large-scale building schemes have made it necessary to improve environmental conditions in towns and cities in ways that are more economical of resources, less disruptive to communities and more open to participation by residents.

A Group on the Urban Environment of OECD's Environment Committee has drawn up a list of these techniques in a recent report which includes specific examples drawn from Member countries (1).

国 $\mathrm{t}$ is difficult to define precisely what a low-cost improvement to the environment is, since the term is a relative one, but it is generally applied to a cost which is closer to that of maintaining existing structures than to that of replacing them.

Low-cost improvements to the environment have the advantage of flexibility. They can be tailored to a particular locality and phased in or out to suit local needs; they can even be temporary or experimental in nature and can be abandoned if they do not work. They are thus directed not so much at final solutions as at a continuous attempt to enhance the quality of urban life.

The nature of low-cost improvements is such that those who are to enjoy and use them can most adequately express their needs for improvement while city planners and administrations have the expertise as to cost and benefits of different types of measures.

Tenants' and residents' associations, as well as other civic groups, generally prefer to be consulted on the selection of lowcost improvements in their particular area. Where neighbourhood or district councils exist (39 such groups were set up in Oslo in 1973 , and local government reform provides for elected community councils in Scotland and Wales), they too may be given powers to implement environmental improvements.

It is essential that such measures be taken within the existing decision-making and administrative structures, but this is not always easy since different administrative bodies are likely to be responsible for the various measures included in a low-cost improvement project. Experience in OECD Member countries shows, however, that minor administrative adjustments and coordination suffice to permit application of the appropriate procedures.

Because of the need to establish close contacts with local residents, shopkeepers, industrialists and others, and because of the small scale of individual measures and the need to integrate the activities of public construction firms with those of the police, traffic managers, educational, social and cultural insti- tutions, some cities have decentralised responsibility, taking power from city hall and giving it to ad hoc groups working in the areas where improvements are to be made.

An ad hoc working group of this kind has been set up in Oslo, with direct links to a steering committee of elected officials. Liverpool has appointed an "area executive" who works with residents in a specific district and with a local team of officials drawn from several departments. Methods of linking this area team to councillors representing wards within the area are being investigated.

Technical assistance teams, national community award programmes and competitions are used successfully by many OECD countries such as France, Germany, Denmark, Italy and the United States to get local government involved in environmental improvement programmes and to stimulate local capabilities. In France, three-man mobile teams of architects are used experimentally to evaluate the opportunities for low-cost improvements in small and medium-sized towns. They visit the spot, interview local officials and carry out surveys. Their object is not to draw up programmes of work, since they are not funded, but to heighten the public's awareness of the need for improvement.

During the past ten years, two national competitions a year have been sponsored by the Federal Republic of Germany with the aim of inducing small and medium-sized municipalities to enhance the visual appearance of their towns, improve infrastructure and administrative facilities. A third annual competition is concerned with improving the integration of industrial plants into the urban and rural landscape.

Existing legislation may, because of its fragmented nature, be a barrier to carrying out combined projects for low-cost improvements. The powers needed to introduce even quite simple changes may be split up among housing, planning and traffic authorities and vested in different laws resulting in time-wasting procedures. Where this is so, new legislation designed to facilitate the speedy execution of low-cost improvements is necessary.

Such institutional changes associated with area improvement may in the longer run imply more far-reaching effects on the operations of local government. Though starting as an effort to improve the physical conditions of houses and streets, the move-

(1) The report deals with existing urban areas (buildings, streets), outdoor activities and their improvement, measures for reducing the danger and disamenity caused by vehicular traffic and parking and for improving the appearance of towns and cities.

This report, along with one on urban environmental indicators (The OECD Observer, No. 78, November-December 1975), the conclusions of an OECD Conference on "Better Towns with Less Traffic" (see OECD Observer, No. 75. May-June 1975), and an audio-visual display on urban transport and low-cost methods for improving the urban environment, make up the OECD contribution to the United Nations Conference on Human Settlements - HABITAT - to be held in Vancouver, Canada, 31st May-11th June 1976. 

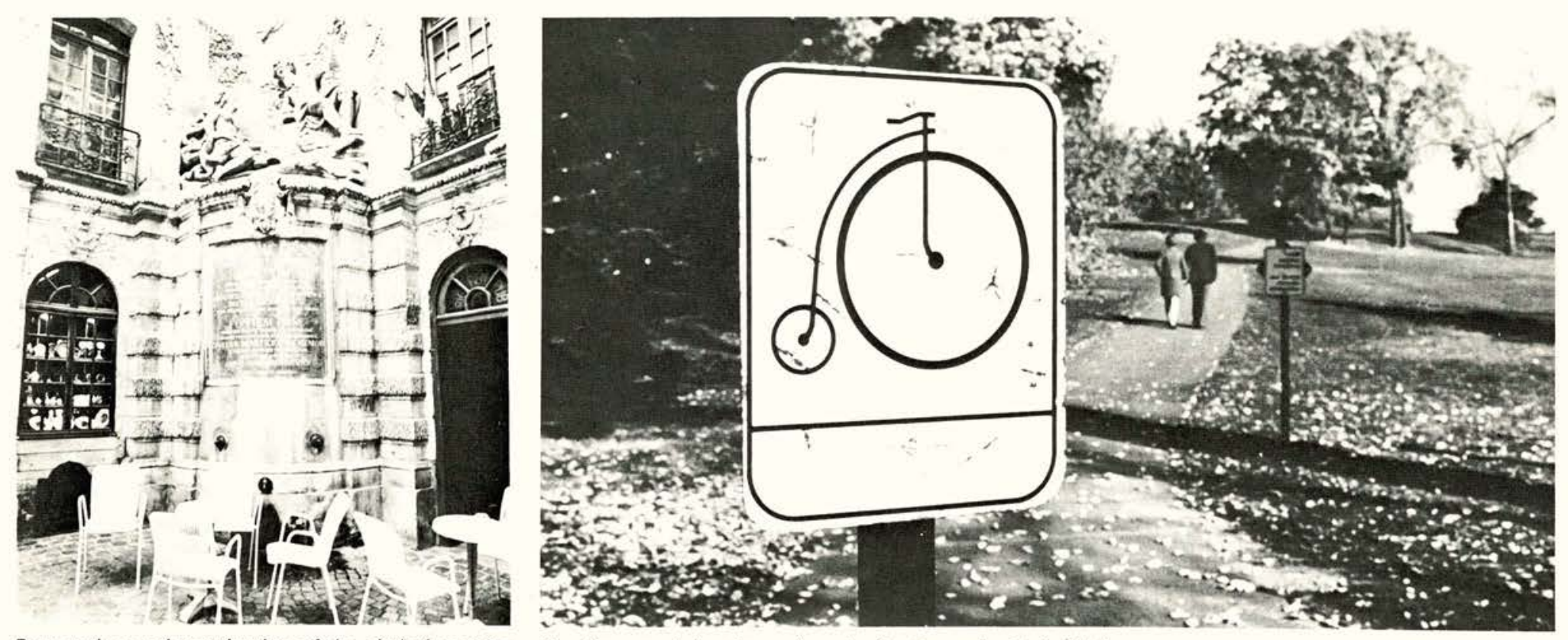

Restoration and reactivation of the city's fountains.

Creating special paths and routes for two-wheeled vehicles.

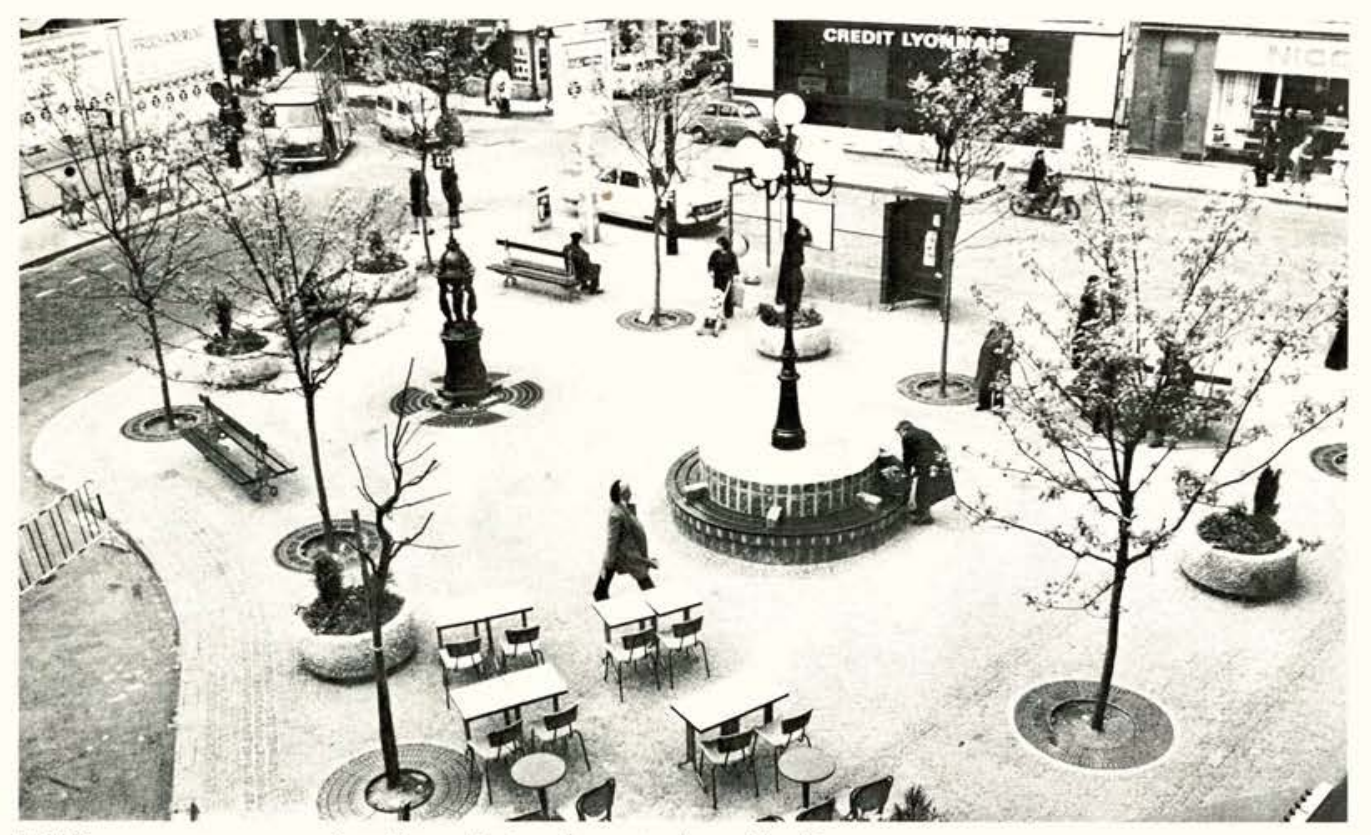

Making a square more attractive : plants, places to sit, café tables.

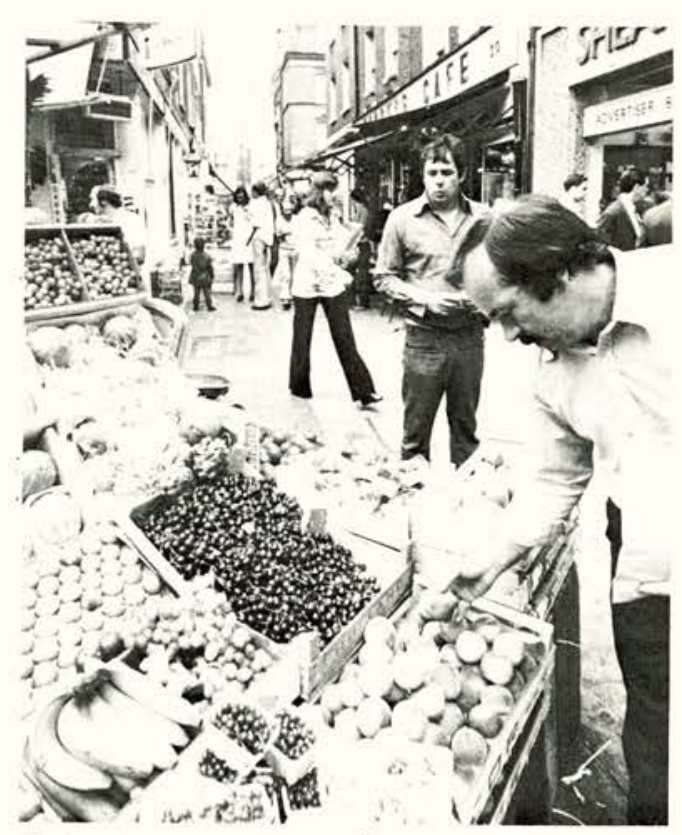

Protection and upkeep of markets.
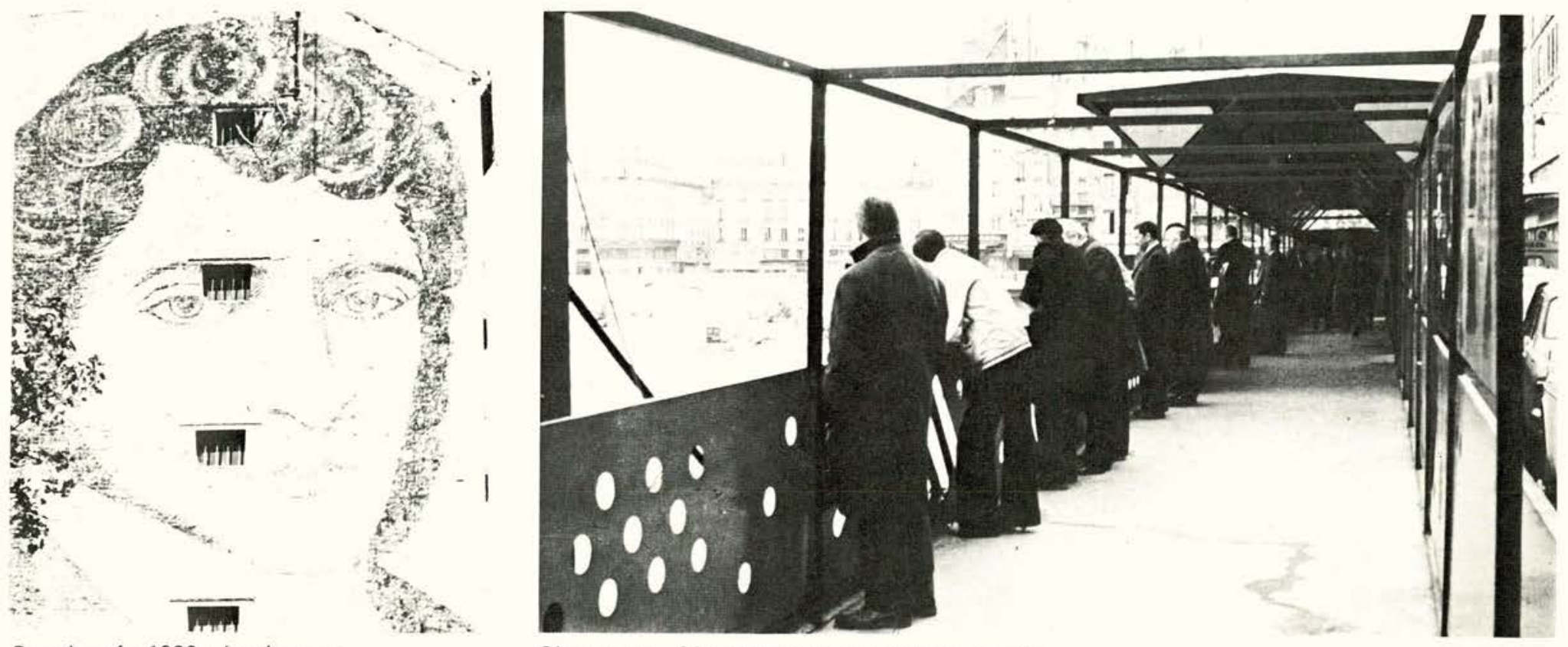

Remains of a 1930 advertisement.

Observatory of les Halles construction site (Paris). 
ment for environmental renewal has tended to evolve towards community development and become increasingly committed to social concerns. This in turn has led to experiments with administrative and political structures that are more responsive to local needs.

The implementation of low-cost urban improvement programmes may help townspeople to acquire a new sense of control over and responsibility for their local surroundings in addition to its role in removing dangers, eyesores, noise and pollution. As a result, the citizens involved may acquire not only a better physical environment but at the same time a greater sense of well being and the feeling that they have a voice in deciding what the future of their neighbourhood is to be.

Low-cost improvement projects must not however be considered in their local context alone. They are also practical steps towards the fulfilment of general planning goals of an urban policy which covers the entire city or region. The physical, social and economic implications of local projects must therefore be regarded as part of a comprehensive planning scheme for the community as a whole involving the coordination of priorities for improvement under the auspices of a general master plan.

The urban crisis is a grave problem for many countries. Since the majority of the population lives in urban areas, low-cost environmental improvement in the cities is also a matter of concern for national policy.

Governments should consider legislative, administrative and financial measures designed to stimulate the development of strategies for low-cost improvement as part of their comprehensive urban planning, OECD's report notes. Better information on such measures is essential and research efforts should therefore be stimulated in order to test the results obtained and improve the techniques used.

\section{What Low-Cost Improvements Are Possible?}

Improving the urban environment may have differing objectives: the aim may be to renovate an existing asset which has been neglected or encroached upon or is endangered; or it may be to alter the function of some area-completely or in part- or to make better use of the overall environmental potential.

\section{IMPROVEMENTS TO EXISTING ASSETS IN BUILT-UP AREAS AND OPEN SPACES \\ Measures to Protect Urban Sites}

\section{Built-Up Areas}

- Face lifting of buildings

- improvement of housing conditions

- clearing of inner courtyards

- Monitoring of shop fronts (integration with architecture of building and street) and of shop and advertising signs

- Cleaning and repairing of building fronts

- Decoration of blind walls

\section{Open Spaces}

\section{- Streets}

- protection of existing street furniture

- installation of new street furniture

- planting greenery and flowers

- pollution control

- improvement of traffic signs and signals

- elimination of overhead power lines

- better integration of public lighting

— fixing up building sites

- Areas around monuments, buildings, shopping centres, construction sites, etc.

- Landscaping

- Public squares

- paving, benches, lighting

- Public gardens

- removal of iron fences

— setting up playground equipment

- Street life

- protection, maintenance and creation of open markets

- protection of street commerce

\section{CHANGING USE OF OPEN SPACES}

- Limiting traffic in the inner core of the city to make way for public transport

- reserved bus lanes

- establishment of car parks on the periphery

- Encouraging two-wheeled vehicles

- creating special paths and routes

- creating special parking facilities

- Bringing back the pedestrian

- widening pavements

- setting aside temporary or permanent pedestrian streets

— fitting out town squares

- creating new footpaths through courtyards of buildings, gardens, etc.

- giving the public temporary access to areas cleared by demolition (adventure playgrounds) - planning for use of abandoned areas (old railbeds)

- landscaping of river banks and laying of walks

- Using streets and town squares for cultural or recreational activities

- Providing mobile cultural and recreational facilities

- Use of temporarily open spaces e.g. setting up of car parks or adventure playgrounds on construction sites

- Provision of facilities which allow the public to follow the progress of work being done by the town

- CREATION OF NEW OPEN SPACES OR OPENING EXISTING SPACES TO THE PUBLIC

\section{ADMINISTRATIVE MEASURES BY LOCAL AUTHORITIES}

- Improvement of public services

- special transport facilities for old people. handicapped persons, children and other groups to specific activities or recreational areas

- organisation of cultural and recreational activities such as fairs or sporting events

- socio-cultural, educational and socio-economic services

- other public services such as protection, surveillance and cleaning

- Creation of new bodies

- town planning agencies

- official or unofficial committees to monitor the quality of public or private urban-improvement projects

- creation of an agency responsible for maintaining and protecting historical monuments and natural or man-made sites

- formation of committees to draw up general action programmes for improvement of the quality of the urban environment

- Regulations and other measures by local or regional authorities

- monitoring of architectural and townplanning quality

- information on architectural and townplanning quality

- land-use specifications

- organisation of competitions

- setting up criteria for the selection of

architects for public projects

- promoting the quality of projects

- Allocation of funds for works of art and other amenities

- Allocation of funds for planting, paving, lighting and provision of street furniture

- encouraging developers to devote greater attention to the social and physical environment of specific projects

- encouraging the public to participate in decision-making

- Other methods to

- create a favourable climate of public opinion

- encourage the participation of commercial and industrial enterprises in urban improvement 


\section{Building for Educational Change}

Spending on education is now a massive item in national budgets. In the United Kingdom, to take only one example, it accounted for 12 per cent of public spending in 1973-1974, costing one-fifth more than health and personal social services and a third more than either defence or housing. Most of this money meets recurrent costs.

It is the financial input into, so to speak, the education industry. But like any other industry,

the effectiveness of education depends on having the right kind of capital equipment, using it to good purpose,

and keeping it up-to-date. School buildings, with their furniture and associated equipment represent,

in effect, the major capital asset of education. To help promote innovation and change in current school building

practices, OECD has set up a Programme for Educational Building in which eighteen Member countries

participate formally and several others informally.

The following article, written by Guy Oddie, Senior Advisor to the OECD Programme and Professor of Architecture

at Edinburgh University, illustrates the scope of the programme and describes several of its results.

\section{The Right Kind of Building}

\section{- Effect of New Modes of Learning}

Getting value for money means first of all getting buildings of the kind that suits the activities which are to go on in them. This may seem simple enough if education is seen in terms of class-based expository teaching or in terms of work at benches in laboratories or workshops. In some schools education is still seen this way. But it is now widely recognised that effective education, which uses valuable teaching skills to best advantage, demands a much richer mix of activity. And if school buildings permit no more than the comparatively restricted activities of tradition, then the newer more effective modes are inhibited. To that extent, if new buildings are built in this way, not only is the capital expenditure ineffectively used, but so is the recurrent expenditure on teachers' pay. Policies are needed which prevent this from happening. Similar policies are also needed to allow for existing buildings to be re-modelled.

The newer modes of learning still require areas for formal instruction, lectures or demonstrations. But there is a desire, also, for less rigidly predetermined spaces reflecting the need for teachers to be able to seize a learning opportunity when it presents itself and to structure their teaching around it. So space is needed for small groups, for discussions and seminars; for indepen- dent study and investigation; for teams of teachers to discuss common projects and prepare teaching material, and for accommodating new teaching/learning resources, such as tapes, film-strips, computer terminals and so on, to which pupils as well as teachers need easy access. These are the needs expressed by leading educationists and the more adventurous of practising teachers. But, in too many instances, when architects have asked them to be specific about how many and what size of space are needed in any particular building, they have been unable to give a clear answer, for they are not used to seeing educa-

1. Maiden Erlegh Secondary School

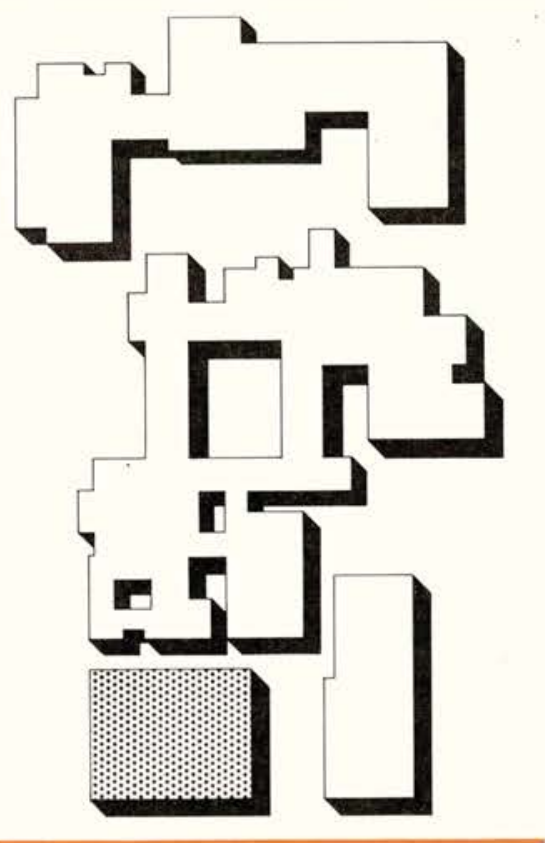

tional ideas in terms of physical requirements. Architects have therefore tried to get round the difficulty by providing large areas of undivided space, hoping that teachers would then create, by means of movable partitions or varying furniture arrangements, the kind of space division they wished to have. But this has not worked either-because what is important to teaching is not just the size or number of spaces, but the kind and quality of environment which each of them provides. Thus the Programme has shown that, even when traditional building patterns have been left behind, much of the money spent has gone on the wrong kind of building.

Fortunately, however, the Programme has also been able to draw attention to examples where this has not been the case.

\section{- An Example}

One such example will illustrate how building can facilitate the newer modes of teaching and, more importantly, how abstract concepts can, if the right communications between educationists and architects are established, be translated into practical reality.

Figure 1 shows the block plan of an English secondary school which has been recently extended in order to increase the number of pupils accommodated and to cater for the wide range of educational activities associated with comprehensive education for the 11 to 18 year age group. The extended build- 
2. Headquarters of the 11 to 13 age group in the school shown in Figure 1 ; (below) rearranged to accommodate an adult education centre

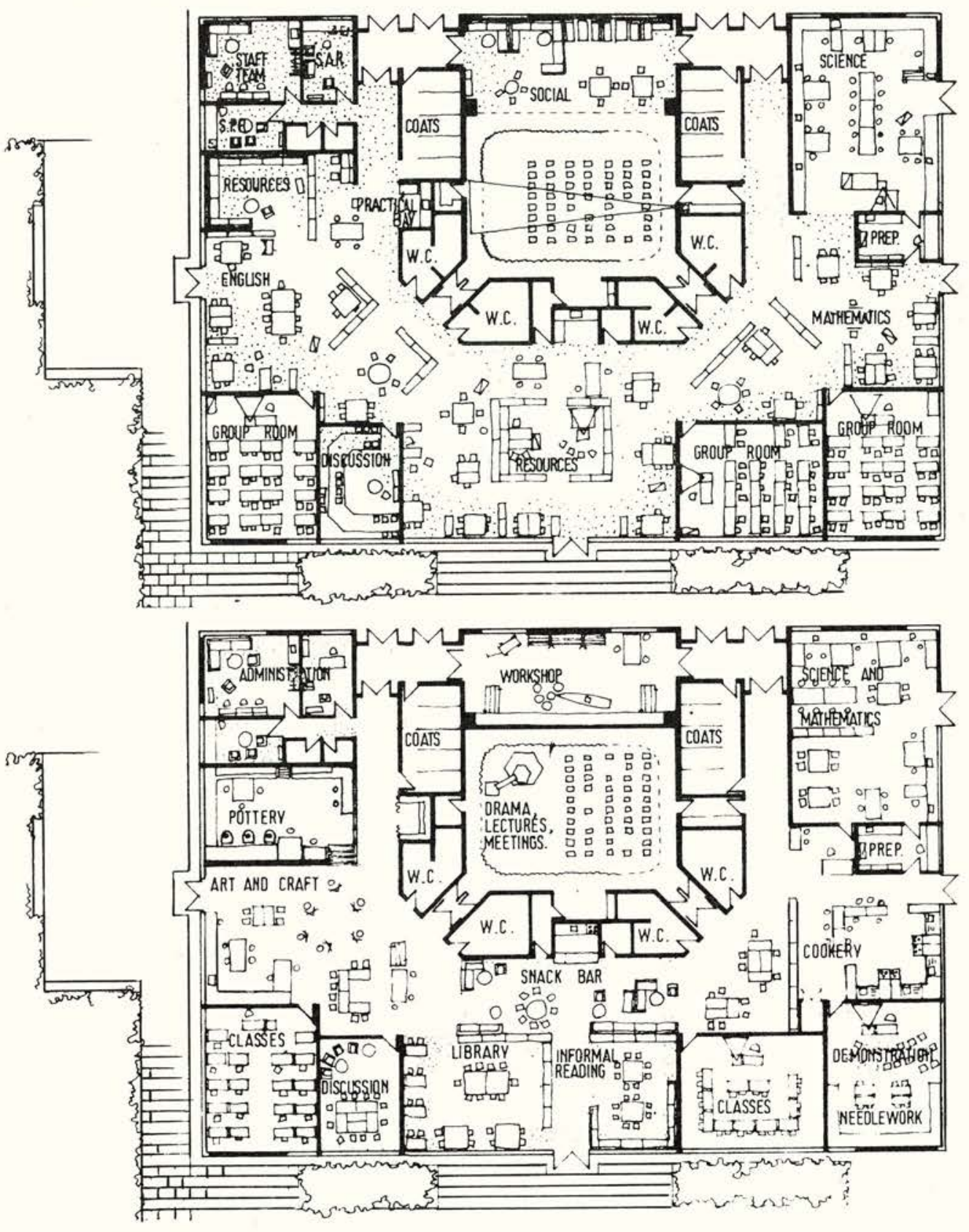

ing consists of the original building and a number of additional separate blocks, each tailor-made to a different set of requirements. Figure 2 shows the detailed plan of one of these blocks which is intended to serve as the headquarters of the 11 to 13 year olds.

Only three of the spaces in this block (accounting for only about 12.5 per cent of the floor area) in any way resemble or can be used as traditional classrooms. Yet the number of pupils which the block may accommodate at any one time can be the equivalent of about eight or nine classes. This means that at any given moment some two-thirds of the pupils are engaged on activities outside the traditional classroom, with perhaps two may gather a small group of pupils together and go with them into the discussion room to talk over the results of their work.

Not all the activities pursued by the 11 to 13 year olds in this particular school will take place in this particular block which is their headquarters or base. They will move to another part of the building for music and drama, for example, or for arts and crafts, or for physical education. But it will be noted that in this one block alone quite a variety of accommodation is provided. Some of the accommodation has special environmental requirements, like the auditorium, or needs special servicing like the science laboratory. Other parts like the group rooms or the discussion room need aural and visual privacy so that class and teacher can be undisturbed and will not disturb the individual work going on in the general space; and each of these reserved spaces needs particular dimensions to suit the size of group which occupies it.

\section{- Educationists as Architects}

The importance of the successful example just described is not as a model to be copied. On the contrary, its success lies in meeting one particular approach to school organisation and curriculum. Its importance lies in the means that were employed to translate the organisational and curricular concepts into terms of built facilities. The architects did not draw the plan from thin air. The plan evolved as the result of an extended dialogue between architects and educationists. And both the architects and educationists were of a rather special kind. The architects had accumulated a long experience, based on first-hand observation of teachers attempting to overcome the obstacles presented by buildings unsuited to their aims, while the educationists, as the result of equally long experience, had developed acute insights into the physical implications of new educational approaches. In other words, the architects had unusual expertise in educational problems and the educationists were halfway to being architects themselves.

The Programme suggests that all countries need to increase the number of senior and experienced teachers who, mainly as the result of in-service training, can engage in effective dialogue with architects in formulating and developing design briefs. A similar need exists to take more positive steps to familiarise all 


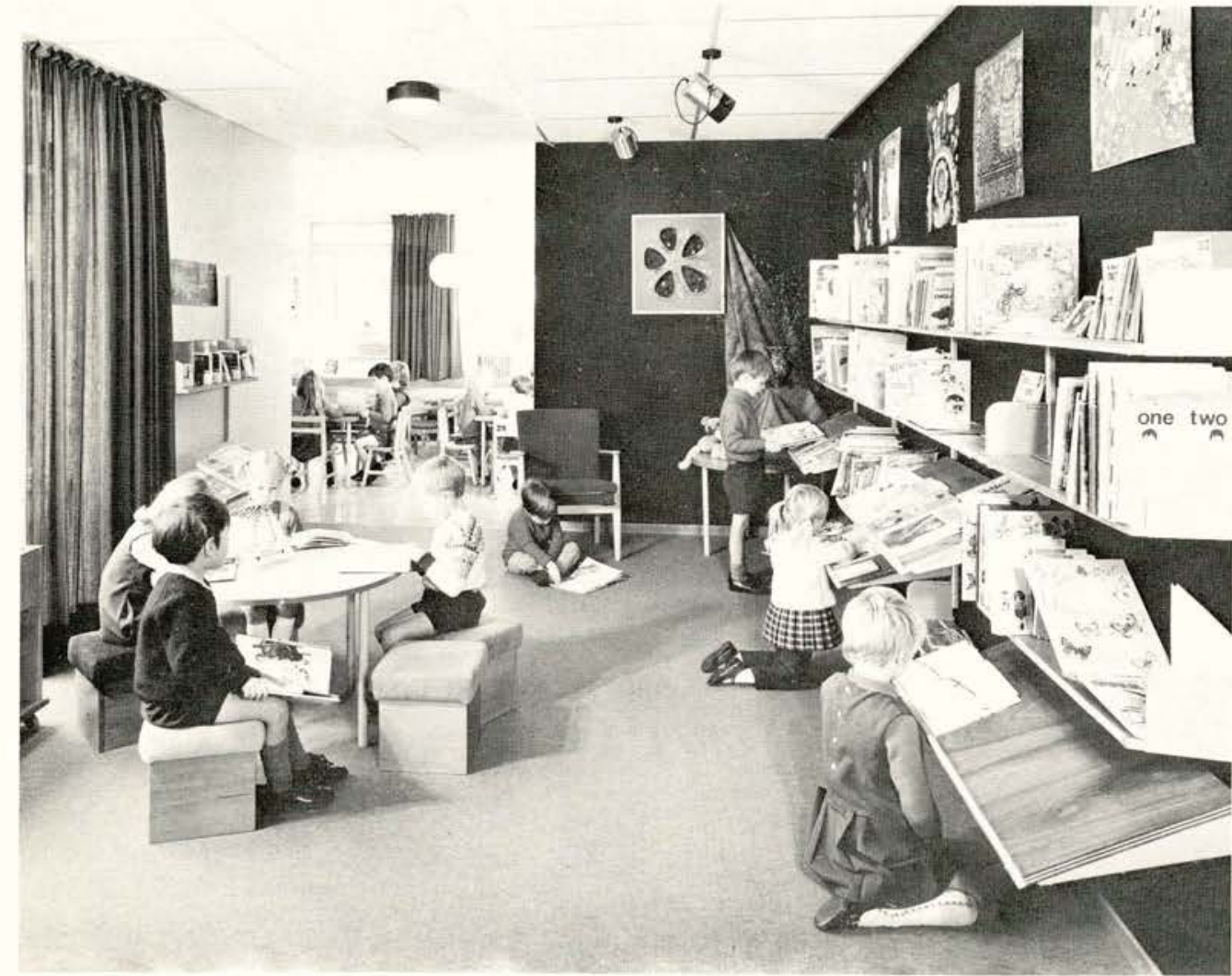

New modes of learning require new kinds of accommodation allowing diversity of activity and environment. A corridor in an old school transformed into a reading space.

teachers with the opportunities which new buildings, when well-designed as the result of such dialogue, can provide for enriching educational activity.

\section{- Architects as Explorers}

The dialogue is of even more importance and needs to be even more exploratory and extensive when new educational concepts are under consideration. The reason is that the building itself, or at least the need to design one, serves as a means of sharpening abstract ideas into proposals for concrete action. The building itself is an important vehicle for change; so that building implications need to be considered not as the last stage in the implementation of educational policies, but at the point when alternatives are considered for the policies themselves. Thus to the architect's role as designer is added a new role of exploration: exploration, jointly with educationists themselves, of the physical implications of alternatives for educational development. And this exploration is directed not only towards the kind of buildings and equipment needed, but equally towards the concrete definition of the kind of educational activity which alternative policies imply.

\section{- The Notion of "Development Projects".}

In the end, of course, the exploration must culminate in real buildings, not in isolated or exotic experiments, but in buildings which, subject to the prevalent constraints of cost and time, indicate the direction which school buildings in general can feasibly take in reponse to changing educational-or economic or social-developments. Such buildings constitute, in effect, development projects.

All the activities of the Programme have led to a key conclusion: close educationist/architect collaboration on development projects is central for succes in getting the right kind of school buildings.

\section{Balancing the Budget for School Building}

\section{- Importance of Norms and Standards}

Do the new modes of learning demand more expensive buildings? Not necessarily so. One of the most important findings from the Programme is the great variation that exists between countries in the building resources put at the disposal of schools of similar type and size. For example, floor areas (a major cost determinant) in secondary schools vary between countries from less than $7 \mathrm{~m}^{2}$ per pupil to as much as $20 \mathrm{~m}^{2}$. Yet examples have been found where the new modes of learning are satisfactorily pro- vided for within the lower figure. Thus over Member countries as a whole there is considerable scope for economy without jeopardising educational needs.

The Programme has indicated that to secure these economies a number of important steps are necessary, particularly with respect to the norms and standards which apply to school building. In many countries those currently in force attempt to specify the nature and quality of buildings (and by implication the consequent costs) by means of standard schedules of accommodation or by prescribing the dimensions and shape of rooms. But to do so overlooks the dynamics of education in which as new needs arise, old ones disappear. Such norms create the risk that redundant provision will be retained and desirable innovation inhibited. They need to be revised if resources are not to be dissipated on meeting needs which no longer exist or on making provision for new need that is so inadequate as to be less than fully effective.

\section{- Standard Cost Limits}

Some countries have been successful in getting rid of obsolete provision to make economic room for new requirements. Here an important aid has been what may be described as a "standard cost strategy". This strategy recognises that "the right kind of building" can not be specified in precise terms. Between what is educationally acceptable or unacceptable there is no hard dividing line, but rather a wedge: a wedge of opportunities which increase or decrease according to how sharply costs constrain them. Thus standards of quality may vary from the thin to the thick end of the wedge, but costs can be made to conform to a single standard-which of course can be raised if too many buildings have to make do with the thin end.

Both educationists and architects have been found to respond well if given the chance to collaborate in getting the best building they can within a standard limit of cost. Knowing that they will get no building at all if they exceed the limit, they have every incentive to keep within it. Knowing that they can not, so to speak, "keep the change" if they spend less, they have every incentive to get maximum value for the money allowed. The discipline that a standard limit imposes has been a major contributor to the success of development projects and has ensured that the proposals they incorporate are realistic in terms of wider practice. 


\section{- Reducing Costs by More Intensive Use}

One way of keeping expensive floor area towards the lower end of the range is to ensure that the minimum of accommodation is reserved for activities which occupy only a few hours of the teaching day. Old school buildings, which include such items as assembly halls or lavish circulation areas offer considerable scope for more intensive use if these parts of the accommodation can be converted to other uses. In this respect properly designed furniture and equipment have an important contribution to make, and so form another topic of investigation under the Programme. Well-designed furniture can also mean that less area is needed for a given activity and that a wider range of activities can be accommodated in the same space.

Even more effective in making economies by more intensive use is to extend the hours during which the building can be used, not only by the school-age population but by the community at large. Thus the coordination of school and community facilities represents yet a further interest of the Programme, an interest which is also bound up with problems of location.

\section{The "Right Place"}

Many present examples of coordinated school and community facilities stem from no more than the desire to intensify their use. But even greater importance is lent to such coordination by the new role envisaged for education as a stimulus in community development. A growing body of opinion holds that education can no longer be confined within the sole realm of the school; it must form an integral part of more global policies aimed at meeting a variety of cultural and social needs. Whereas school building has been seen, until recently, as independent of building for other purposes, such independence now seems likely to give way to interdependence. And the buildings provided will need to promote the inter-action of education with other sectors of social activity such as health, welfare and recreation

For both economic and social reasons many countries are now seeking to renew and revitalise the inner areas of towns which earlier expansion has left derelict or almost abandoned. Steps towards this end, such as the increase in the ratio of housing to offices or other work milieu, and the introduction of new transport modes and networks, may increase the number of people seeking educational services, despite a stabilisation or even decline in the numbers subject to compulsory schooling - a fact which may make it necessary to find new uses for existing school facilities. Certainly the pattern of population distribution is likely to be changed. And the new population patterns will probably coincide only rarely with the distribution of existing facilities. Thus besides the considerable problems of what kind of facilities are necessary (and can feasibly be provided) there is the equally considerable problem of where they should be located to meet social and economic objectives in re-shaped networks (1).

\section{Getting Buildings Quickly Enough}

At some time or other, most Member countries have encountered emergencies in meeting educational demand which could only be met by stop-gap industrialised buildings. On the other hand, industrialised building has been the means, in some cases, of not only meeting emergencies but of sustaining large scale investment programmes over extensive periods of time, with a resulting quality as high as that usually obtained from conventional alternatives. This, and the merits of industrialisation in general, have tempted many policy-makers to believe that industrialised methods might hold the key to providing school building both at acceptable cost and at the required tempo. Another activity in the Programme has been concerned, therefore, to test this view and to identify the policies needed if such methods are to be used to best advantage.

The first conclusion from this activity is that industrialised building comes into its own when the building industry of a country is unable to meet demand solely by conventional methods. The tendency then, however, is for industrialised building systems to be developed in response to general market needs. If the particular (and different) needs of education are not to be neglected as a consequence, educational interests need to be effectively represented in the development of these systems. Such representation demands once again, the closest partnership between architects and educationists in determining the kind of building which systems must be able to produce. It also demands measures to promote a positive flow of communication between the architect/educationist partners and the system producers, as well as between these and the administrative mechanisms responsible for commissioning buildings, furniture and equipment.

(1) A second symposium on School and Community Building in relation to Urban Dynamics, is planned as a Programme activity for the autumn of this year.

\section{OECD's Educational Building Programme}

The purpose of the Programme is to provide for the exchange of information and experience among Member countries which will help them to use their school building resources as effectively as possible.

It does this in three ways. First, by publishing short leaflets summarising emerging issues or innovatory activity in different countries. These are not definitive studies, they simply provide early notification of topics which individual countries will find useful to follow up on their own account.

Secondly, the Programme undertakes in depth studies of major issues concerned with getting value for money, in terms both of new buildings and optimum use of the existing stock. The studies are carried out by expert consultants in collaboration with the Secretariat and result in published reports available through the Organisation's usual distribution channels. They represent the major effort in the Programme.

But, however widely publications may be disseminated and read, they are no substitute for personal contact. Finally, therefore, the Programme arranges for occasional international follow-up symposia at which senior administrators, educationists and architects can exchange views and provide information about experience in their respective countries. The first of these, held at Buxton, England, was concerned with school building and educational change; another on school and community building is planned for the autumn of 1976 . 


\section{Provision for Future Change}

Buildings, by their nature, tend to outlive the purpose for which they were originally' intended. What steps can be taken, therefore, to make them easily adaptable to meet the requirements of an unforeseeable future?

In setting out to answer this question the Programme has, to begin with, made a useful distinction between adaptability and flexibility. Adaptability is the characteristic which enables subsequent alteration to be made to the physical fabric of the building. Flexibility has been defined as a quality in the building as originally planned-a quality which allows new purposes to replace old ones without any need for physical adaptation. The greater the flexibility, the less likely is adaptation to be needed.

\section{- Aids to Flexibility}

The educational practices now gaining currency support such flexibility. They are best satisfied by a balance of, on the one hand, specialised accommodation committed to a variety of specific purposes, and on the other, general spaces suited to the wide range of less specific activities which occupy the greater part of the timetable. OECD's Educational Building Programme has shown that accommodation balanced in this way, and carefully planned to allow the free flow of activities from one kind of space to the other, can provide for many alternative educational requirements. The lower part of figure 2 shows the same building but accommodating an adult education centre instead of the 11 to 13 year olds for whom it was first intended. For such a change, no adaptation is required, the plan itself having sufficient flexibility.

\section{- A Strategy for Adaptability}

But if flexibility is the first line of defence against early obsolescence, what resources may still be merited to provide for adaptability? OECD's studies have suggested a strategy for maximising adaptability without higher first costs or sacrifice of present needs. Physical adaptation means, in effect, removal, replacement, addition or relocation of building components. To spend money on maximising the relocatability of components which may never need to be relocated is to pay in advance for a very uncertain benefit. The preferable strategy is to "pay as you go" by deferring expenditure until adaptation proves to be needed. The studies suggest technical means whereby expenditure on eventual adaptation will not be increased by the nature of the initial provision.

The investigation has thus shown that there is no need to sacrifice the known needs of today to the unknowable needs of tomorrow. At the same time it has provided the warning that adaptability is no substitute for determined decisions about the form buildings should take if present needs are to be properly met.

\section{Value of the Programme}

Education in many countries is now moving in directions which imply complex consequences for educational building. While the number of children of compulsory school age is stabilising or declining, emphasis is shifting to demands for pre-primary and post-compulsory and recurrent education in various forms. More attention is being paid to the special needs of the under-privileged, to provision for "drop-outs" and to the role of education in community development. The resulting new activities will demand new kinds of buildings, either new or converted. The interaction of education with other community services will require new arrangements for inter-sectoral cooperation. Clearly educational building problems will continue to loom large in the years ahead.

The Programme has laid the groundwork for tackling these emerging problems systematically. Practical application of the conclusions as a whole should result both in substantial savings and increased efficiency through more rational use of available resources.

Economical management of educational building resources is not primarily a technological matter, however important technology may be. Rather it demands that education itself, educational planning, building technology, design and procurement processes, and institutional arrangements too, constitute a network of related issues which have to be regarded as a totality. In this respect educational building need not be seen as more difficult to manage or more peculiar than building for other purposes. On the contrary, it represents a convenient and comparatively easily-handled model which deserves attention from anyone concerned with the effective use of resources in providing a built environment responsive to social, economic and cultural needs.
$\mathrm{O}$ April 13, Gamani Corea, Secretary General of the United Nations Conference on Trade and Development (UNCTAD) was received at the Château de la Muette.

As his predecessors in office, Raoul Prebisch and Manuel Perez Guerrero, had done in the past, Mr. Corea addressed the OECD Council. His speech, dealing with the prospects for UNCTAD IV which takes place in Nairobi in May, was followed by a lively discussion. Mr. Corea's visit was timed to coincide with the third meeting of an ad hoc group set up within OECD, under the chairmanship of Ambassador Luc Putman (Belgium) in order to prepare the UNCTAD conference.

OECD Secretary General, Emile van Lennep, will lead a delegation of the OECD to the Nairobi meeting and will be one of the speakers at the conference.

\section{Inauzural $M$}

A $\mathrm{t}$ its first meeting in Dakar 29th31st March, the Club des Amis du Sahel (see OECD Observer No 79 January-February 1976) decided to create a working group to help elaborate a strategy for the medium - and long term economic and social development of

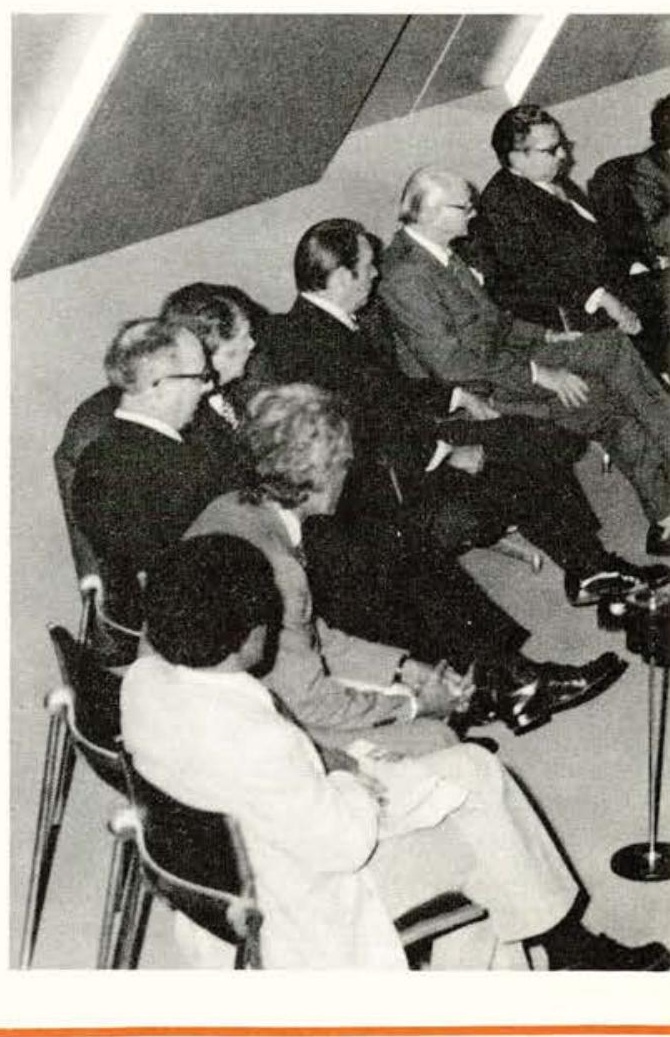




\section{UNCTAD IV}
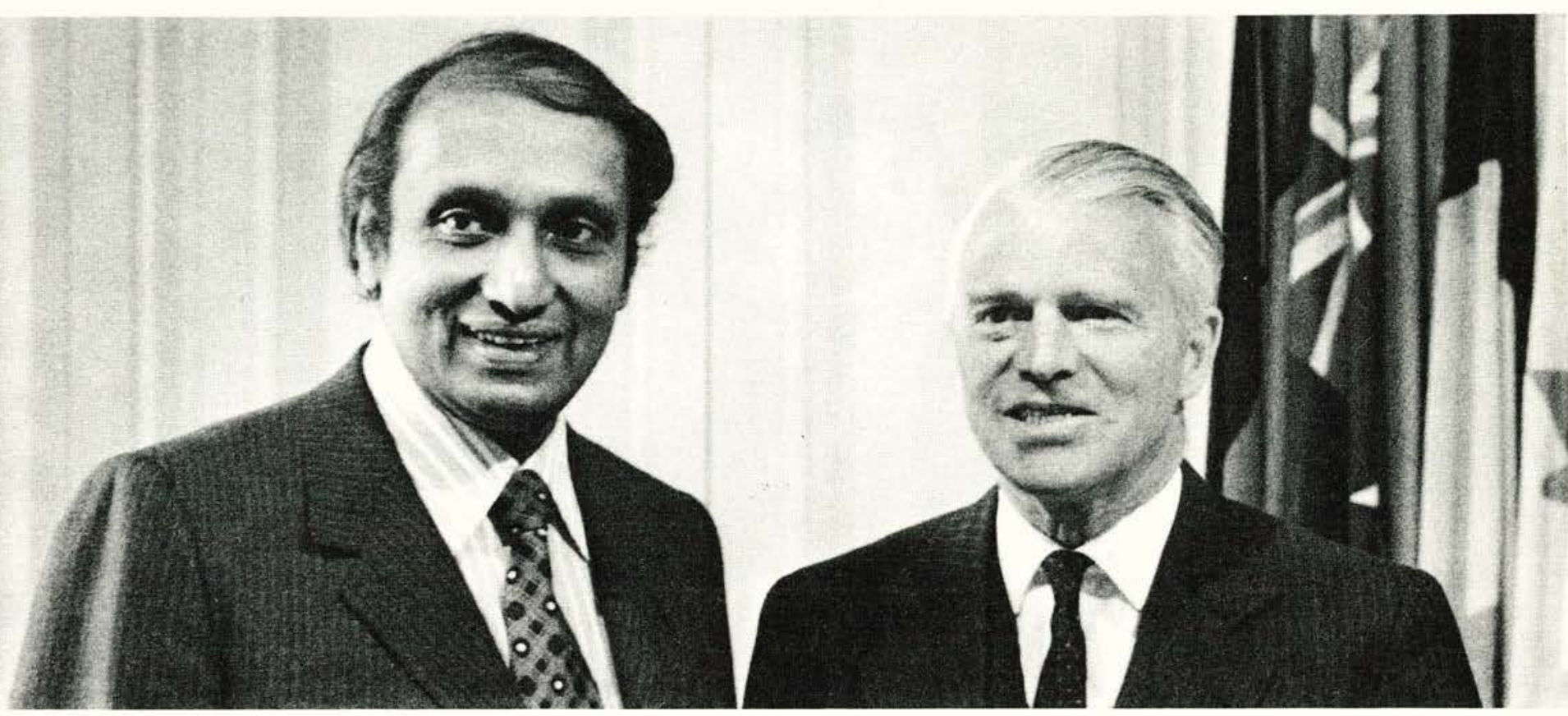

Gamani Corea, Secretary General of the United Nations Conference on Trade and Development (UNCTAD) with OECD's Secretary General, Emile van Lennep

\section{eeting of the "Club des amis duSahel"}

the Member countries of the CILSS (1). The group will be made up of representatives of all member states of the CILSS and of member governments of the Club des Amis du Sahel and of regional and international organisations wishing to participate. The President of the working group will be the CILSS Coordinator Boulama Manga, Rural Development Minister of Niger.

OECD, in close cooperation with the CILSS, has played an important role in the creation of the Club des Amis du
Sahel and will continue to be active in its further work.

(1) The French initials for Permanent InterState Committee on Drought Control in the Sahel. It includes Chad, Gambia, Mali, Mauritania, Niger, Senegal, Upper Volta and Cape Verde Islands.

President Léopold Sédar Senghor of Senegal and President Moktar Ould Daddah of Mauritania, who presided over the inaugural session of the Club des Amis du Sahel, meeting with senior representatives of the OECD countries and international organisations.

From left to right: an aide; Abdalla Ould Daddah, Rural Development Minister of Mauritania: Maurice J. Williams, Chairman of OECD's Development Assistance Committee who played an active role in bringing the Club into existence; Paul Gerin-Lajoie, President of the Canadian Agency for International Development; Daniel Parker, Administrator of the U.S. Agency for International Development; Hans-Broder Krohn, EEC Director-General of Aid and Development; Gabriel Van Laethem, Deputy Secretary General for Economic and Social Affairs, United Nations; Jan D. Pronk, Netherlands Minister of Cooperation and Development; Jean de Lipkowski, French Minister of Cooperation and Development: President Senghor; Anne de Lattre of OECD's Development Cooperation Directorate; President Ould Daddah: Abdou Diouf, Prime Minister of Senegal ; Adrien Senghor, Senegalese Minister of Rural Development; Emile van Lennep, OECD Secretary General; Ernst Veselsky, Austrian Secretary of State to the Federal Chancellor. 
"OECD Economic Surveys". 1976

\section{Series:}

Detailed annual surveys of trends and prospects for each OECD country.

FRANCE (January 1976)

(1076141) ISBN 92-64-11458-0

\section{UNITED KINGDOM}

(February 1976) (1076281) ISBN 92-64-11459-9
64 pages

SWITZERLAND (March 1976) (1076261) ISBN 92-64-11470-X 66 pages Each booklet ..... \& $1.10 \$ 2.50$ F 10.00
Subscription to the 1976 series:

\& $20.00 \$ 45.00$ F 180.00

OIL STATISTICS, 1974. Supply and Disposal / STATISTIQUES PÉTROLIÉRES 1974. Approvisionnement et Consommation (March 1976)

Statistics covering all Member countries including supply and disposal of crude oil, feedstocks, components and petroleum products: sources of imports: processing of crude oil. feedstocks and natural gas: refinery output and consumption of main petroleum products. (6176 20 3) ISBN 92-64-01463-2 220 pages, bilingual. \&6.00 \$13.75 F 55.00 THE PULP AND PAPER INDUSTRY, 1974-1975 / L'INDUSTRIE DES PATES ET PAPIERS (February 1976)

1974 will undoubtedly remain in the annals of the pulp and paper industry as the year in which the most abrupt and far-reaching reversal occurred in the economic trend This analysis of the prevailing situa tion in 1974 and the trends of the first semester of 1975 precedes some 60 statistical tables on production capacity, production, trade. apparent consumption of pulp. paper. cardboard and fibre building board (by categories of products and by country).

(71 7660 3) ISBN 92-64-01461-6

210 pages, bilingual. \&4.40\$10.00 F 40.00

PROVISIONAL OIL STATISTICS BY QUARTERS. 3rd Quarter 1975 / STATISTIQUES PÉTROLIĖRES

PROVISOIRES PAR TRIMESTRE (March 1976)

(6075 03 3) ISBN 0474-6015

22 pages, bilingual. £ $0.60 \$ 1.50$ F 6.00

STATISTICS OF ENERGY, 1960 1974 / STATISTIQUES DE L'ÉNERGIE, 1960-1974 (January 1976)

Presents, for each OECD Member country, annual data for a detailed analysis of production and consumption for more than 20 sources of primary and secondary energy. (30 7504 3) ISBN 92-64-01425-X 282 pages, bilingual. £ $5.80 \$ 13.00$ F 52,00

MEAT BALANCES IN OECD MEMBER COUNTRIES, 1961-1974 / BILANS DE LA VIANDE DANS
LES PAYS MEMBRES DE L'OCDE 1961-1974 (March 1976) "Document" Series

Gives, for each OECD Member country. complete and detailed balances (production, foreign trade of live animals, slaughterings, foreign trade of meat, total and per head consumption) for each category of meat (beef, veal, pork. mutton, horse, poultry, other meat. edible offal. total meat). Data cover each year of the 1959-1972 period.

(517601 3) ISBN 92-64-01462-4

128 pages, bilingual. \& $3.30 \$ 7.50$ F 30.00

THE FOOTWEAR INDUSTRY STRUCTURE AND GOVERNMENT POLICIES (March 1976)

Examines the changes that have occurred over the last decade, evaluates their causes and outlines the possible future evolution of the industry: discusses the measures taken by governments and the industry itself. Statistical supporting material is included in the annex. (71 76801 1) ISBN 92-64-11480-7

142 pages... \& $4.40 \$ 10.00$ F 40.00 QUARTERLY NATIONAL ACCOUNTS BULLETIN - December 1975 / BULLETIN DES COMP. TES NATIONAUX TRIMESTRIELS (December 1975)

76 pages, bilingual.
$(3676013)$

Subscription... \& $4.40 \$ 10.00$ F 40.00

"OECD Agricultural Policy Reports" Series:

AGRICULTURAL POLICY IN ICELAND (March 1976)

These reports analyse the problems of agriculture in each Member country and describe policies followed in the fields of markets, prices, structure, etc.

(517602 1) ISBN 92-64-11474-2

$\begin{aligned} 28 \text { pages..... } & \text { \& } 1.00 \$ 2.25 \text { F } 9.00\end{aligned}$

URANIUM. Resources, production and demand including other nuclear fuel cycle data (March 1976)

Forecasts of nuclear electricity generation, and the consequent demand for uranium production, from now to the end of the century. World uranium resources. Demand for enrichment and reprocessing of nuclear fuels, and for radioactive waste management.

(66 76021 ) ISBN 92-64-11471-8

80 pages....... \& $3.10 \$ 7.00$ F 28,00

"International Seminars" Series: 1975-1. WORKERS' PARTICIPATION. Final Report on an International Management Seminar convened by the OECD, Versailles, 5th-8th March 1975 (February 1976) "Document" Series

Workers' participation in management is presently giving rise to controversy. To throw light on this debate, the seminar reviewed recent legal and collectively agreed innovations and initiatives by management. Economic democracy. job enrichment, disclosure of information and training were also discussed.

(83 7601 1) ISBN 92-64-11454-8

96 pages....... £ $£ 2.70 \$ 6.00 ₹ 24.00$

TEACHER POLICIES. General Report of the Conference (March 1976)

Examines implications of the educational innovations at primary and secondary level on the role, the tasks, the pre-service and in-service training of the teachers, and the planning of resources to be mobilised in this field.

(917603 1) ISBN 92-64-11482-3

160 pages.r. $\quad 2.70 \$ 6.00 ₹ 24.00$

ENVIRONMENTAL PROBLEMS AND HIGHER EDUCATION (February 1976)

Examines problems related to the

training or retraining of professionals concerned with the environment, and with environmental research.

(96 7602 1) ISBN 92-64-11472-6

182 pages..... \& $4.40 \$ 10.00$ F 40,00

"Reviews of National Policies for Education" Series:

NORWAY (March 1976)

The basic documents of this review include the Background Report. prepared by the Research and Planning Department of the Norwegian Ministry of Education: the OECD Examiners' Report and Questions: and the Report of the Confrontation Meeting in the OECD Education Committee conducted on the basis of the above two documents.

(917602 1) ISBN 92-64-11481-5

254 pages...... \& $4.70 \$ 10.50 \mathrm{~F} 42.00$

No 10 - POLICY ISSUES IN DATA PROTECTION AND PRIVACY. Concepts and Perspectives (March 1976)

Focuses on: regulatory instruments for data protection: the personal identifier issue and privacy : citizens rights of access to their files: rules for transborder data flows: costs of data security.

(937601 1) ISBN 92-64-11475-0

326 pages...... \& $5.60 \$ 12.50$ F 50.00

\section{Recent Publications on Employment}

SOCIALLY RESPONSIBLE WAGE POLICIES AND INFLATION (December 1975)

A study of how four OECD countries with very different industrial relations systems and wage policy traditions approach the problems of inflation. Covers Germany, the Netherlands, Sweden and the United Kingdom.

70 pages ..... \& $\quad \& 1.60 \$ 3.50 \quad$ F 14.00

THE OECD AND INTERNATIO-

NAL MIGRATION (October 1975)

Examines the development of OECD thinking on the subject of migration against the background of the changing economic and social situation and the Organisation's own activity in this field.

52 pages .... \& $1.10 \$ 2.50 \quad F 10.00$

THE ROLE OF WOMEN IN THE ECONOMY (June 1975)

A summary of reports by ten countries on the composition of the female labour force, the foundations for vocational choice, problems of discrimination, reconciling family and working life and the laws relating to women's work. together with the discussions and conclusions of a meeting of experts on this subject held in Washington in December 1973.

128 pages .... \& $\quad \& 2.00 \$ 5.00 \quad F 20,00$

EDUCATION AND WORKING LIFE IN MODERN SOCIETY (May 1975)

Relations between education and employment in the light of social objectives are analysed under three main headings: a positive policy for working life: an integrative policy for education: more options for the individual within a freechoice society. Recommendations are made for co-ordinated policies. 46 pages ...... \& $\quad 0.80 \$ 2.00 \quad F 8.00$

WORK IN A CHANGING INDUSTRIAL SOCIETY (December 1975) Examines the technological and organisational factors which are changing, or are likely to change. the nature of work and the attitudes of workers and employers.

54 pages ..... $\$ 1.30 \$ 3.00 \quad F 12.00$

\section{Other Related Publications}

CHANGES IN LABOUR-MANAGEMENT RELATIONS IN THE ENTERPRISE, by Norman F. Dufty (May 1975)

Examines the changes that have been taking place in recent years in labour-management relations within the enterprise and elicits the trends which are appearing.

126 pages .... \& $2.20 \$ 5.50 \quad F 22,00$

WAGE DETERMINATION (October 1974)

A collection of reports dealing with various aspects of wage determination and covering: specific groups of workers (the low paid. white collar and highly paid workers in the public sector): norms and systems for fixing wages; government policy and wages.

368 pages .... $\quad$ \& $3.60 \quad \$ 9.00 \quad F \quad 36.00$ 


\section{Whene lo obluin (OECI) Publicalions:}

\section{ARGENTINA}

Carlos Hirsch S.R.L.,

Florida 165, BuENOS-AIRES.

Tel. 33-1787-2391 Y 30-7122.

\section{AUSTRALIA}

International BCN Library Suppliers Pty Ltd., 161 Sturt St., South Melbourne, Vic. 3205. Tel. 69.7601 658 Pittwater Road, Brookvale NSW 2100. Tel. 9382267.

AUSTRIA

Gerold \& Co., Graben 31, WIEN I.

Tel. 52.22.35

\section{BELGIUM}

Librairie des Sciences,

Coudenberg 76-78, B 1000 BRUXelles I.

Tel. 512-05-60, 513-37-36.

\section{BRAZIL}

Mestre Jou S.A.,

Rua Guaipá 518, Caixa Postal 24090,

05089 Sao Paulo 10. Tel. 256.2746/262.1609.

Rua Senador Dantas 19 s/205-6

RIO-DE-JANEIRO - GB.

Tel. 232.07.32

\section{CANADA}

Publishing Centre, Supply \& Services Canada, 270 Albert Street, Ottawa, ONTARIO, K1A OS9.

\section{DENMARK}

Munksgaards International Booksellers, Nørregade 6, DK-1165 CopenHAGEN K. Tel. (01) 12.69.70

\section{FINLAND}

Akateeminen Kirjakauppa,

Keskuskatu 1, 00100 HeLsINKI 10.

Tel. 625.901

\section{FRANCE}

Bureau des Publications de l'OCDE,

2 rue André-Pascal, F 75775 PARIS CEDEX 16. Tel. 524.81.67.

Principaux correspondants

13602 AIX-EN-ProvenCE : Librairie de

l'Université. Tel. 26.18.08.

38000 Grenoble : Arthaud. Tel. 87.25.11.

31000 Toulouse : Privat. Tel. 21.09.26.

\section{GERMANY}

Verlag Weltarchiv GmbH,

D - 2000 Hamburg 36, Neuer Jungfernstieg 21. Tel. 040-35-62-500.

\section{GREECE}

Librairie Kauffmann,

28 rue du Stade, Athens 132. Tel. 322.21.60.

\section{HONG KONG}

Government Information Services,

Sales of Publications Office,

1A Garden Road. Tel. H-252281-4.

\section{ICELAND}

Snæbjörn Jónsson \& Co., h. f.,

Hafnarstræti 4 and 9,

P.O.B. 1131 - REYKJAVIK. Tel. 13133/14281/11936
INDIA

Oxford Book and Stationery Co. :

Scindia House, New Delhi I. Tel. 47388.

17 Park Street, Calcutta. Tel. 24083.

\section{IRELAND}

Eason \& Son, P.O.B. 42,

40-41 Lower O'Connell Street, Dublin I.

Tel. 743935 .

\section{ISRAEL}

Emanuel Brown :

9 Shlomzion Hamalka Street, Jerusalem.

Tel. 234807.

35 Allenby Road, TeL-Aviv. Tel. 51049/54082. 48 Nahlath Benjamin Street, Tel-Aviv.

Tel. 53276 .

\section{ITALY}

Libreria Commissionaria Sansoni,

Via Lamarmora 45, 50121 FIRENZE.

Tel. $579751 / 2 / 3$

Via Bartolini 29, 20155 Milano. Tel. 365083.

Sub-depositari :

Herder Editrice e Libreria,

Piazza Montecitorio 120, 00186 Roma.

Libreria Hoepli

Via Hoepli 5, 20121 Milano. Tel. 865446.

Libreria Lattes

Via Garibaldi 3, 10122 TorINo. Tel. 519274. La diffusione delle edizioni OCSE è inoltre assicurata dalle migliori librerie nelle città più importanti.

\section{JAPAN}

OECD Publications Centre,

Akasaka Park Building,

2-3-4- Akasaka, Minato-ku

TOKYo 107. Tel. 586-2016.

Maruzen Company Ltd.,

6 Tori-Nichome Nihonbashi, Tокyo 103,

P.O.B. 5050, Tokyo International 100-31. Tel. 272-7211.

\section{LEBANON}

Documenta Scientifica/Redico,

Edison Building, Bliss Street,

P.O. Box 5641, BeIRUt. Tel. 354429-344425.

\section{THE NETHERLANDS}

W.P. Van Stockum,

Buitenhof 36, Den HaAg. Tel. 070-65.68.08.

\section{NEW ZEALAND}

The Publications Manager,

Government Printing Office,

Wellington: Mulgrave Street (Private Bag), World Trade Centre, Cubacade, Cuba Street, Rutherford House, Lambton Quay.

AuCKLAND: Rutland Street (P.O.Box 5344).

Christchurch: 130 Oxford Tce (Private Bag).

HAMILTON: Barton Street (P.O.Box 857).

Dunedin: T. \& G. Bulding, Princes Street (P.O.Box 1104).

\section{NORWAY}

Johan Grundt Tanums Bokhandel, Karl Johansgate 41/43, OsLo 1. Tel. 02-332980

\section{PAKISTAN}

Mirza Book Agency,

65 Shahrah Quaid-E-Azam, LAHORE 3.

Tel. 66839.

\section{PHILIPPINES}

R.M. Garcia Publishing House,

903 Quezon Blvd. Ext., Quezon CiTy, P.O. Box 1860 - Manila. Tel. 99.98.47.

\section{PORTUGAL}

Livraria Portugal,

Rua do Carmo 70-74, Lisboa 2. Tel. 360582/3.

\section{SPAIN}

Libreria Mundi Prensa, Castelló 37, MADRID 1. Tel. 275.46.55/276.02.53.

Libreria Bastinos de José Bosch,

Pelayo 52, Barcelona 1. Tel. 222.06.00.

\section{SWEDEN}

Fritzes, Kungl. Hovbokhandel,

Fredsgatan 2, 11152 Sтоскноцм 16.

Tel. $08 / 23.89 .00$.

\section{SWITZERLAND}

Librairie Payot,

6 rue Grenus, 1211 GenèVe 11

Tel. 022-31.89.50.

\section{TAIWAN}

Books and Scientific Supplies Services, Ltd. P.O.B. 83, TAIPEI.

\section{TURKEY}

Librairie Hachette,

469 Istiklal Caddesi, Beyoglu, Istanbul, Tel. 44.94.70.

and 14 E Ziya Gökalp Caddesi, ANKARA. Tel. 12.10.80.

\section{UNITED KINGDOM and CROWN COLONIES}

H.M. Stationery Office P.O. Box 569, LONDON SE1 9NH, Tel. 01.928.6977, Ext. 410 .

or

49 High Holborn

LONDON WC1V 6HB (personal callers) Branches at : Edinburgh, Birmingham, Bristol, Manchester, Cardiff, Belfast.

\section{UNITED STATES}

OECD Publications Center,

Suite 1207, 1750 Pennsylvania Ave, N.W.,

WASHINGTON, D.C. 20006. Tel. (202) 298.8755 .

\section{VENEZUELA}

Libreria del Este,

Avda F. Miranda 52, Aptdo. 60337, Edificio Galipan, CARACAS 106.

Tel. 32.23.01/33.26.04/33.24.73.

\section{YUGOSLAVIA}

Jugoslovenska Knjiga, Terazije 27, P.O.B. 36, BeOGRAD. Tel. 621.992.

Orders and inquiries from countries where Sales Agents have not yet been appointed should be sent to OECD Publications Office, 2 rue André-Pascal, F 75775 Paris CEDEX 16. 


\section{Organisation for Economic Co-operation and Development}

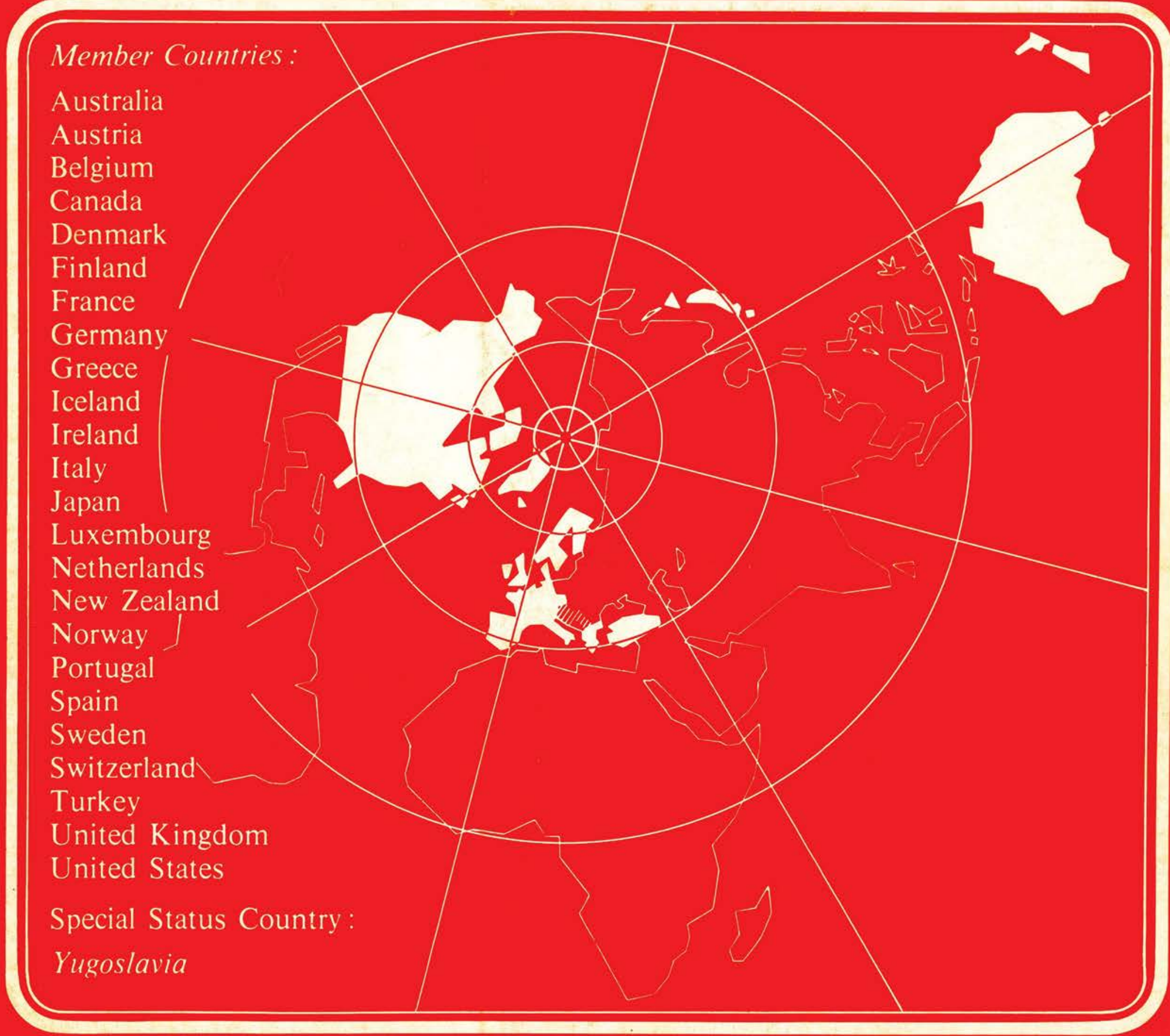

